INITED STATES DEPARTMENT OF AGRICULTURE BULLETIN No. 1027 .

Contribution from the Bureau of Chemistry

W. G. CAMPBELL, Acting Chler

Washington, D. C.

$\nabla$

April 17, 1922

\title{
POISONOUS METALS ON SPRAYED FRUITS AND VEGETABLES
}

\section{BY}

W. D. LYNCH, Assistant Chemist, C. C. McDONNELL, Chief, Insecticide and Fungicide Laboratory, and J. K. HAYWOOD, Chief, Miscellaneous Division, Bureau of Chemistry; A. L. QUAINTANCE, Entomologist in Charge, Fruit Investigations, Bureau of Entomology; and M. B. WAITE, Pathologist in Charge, Fruit-Disease Investigations, Bureau of Plant Industry

\section{CONTENTS}

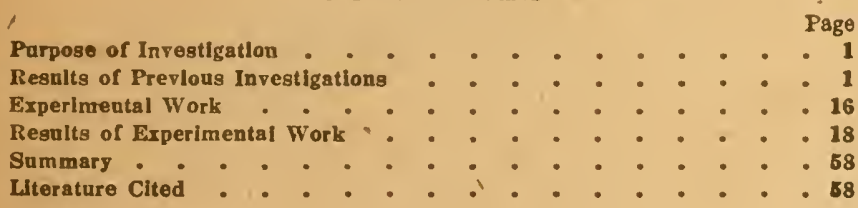

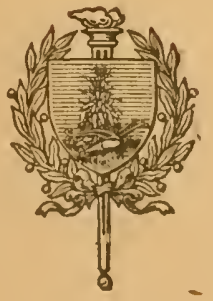

WASHINGTON

GOVERNMENT PRINTING OFFICE 


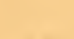

-

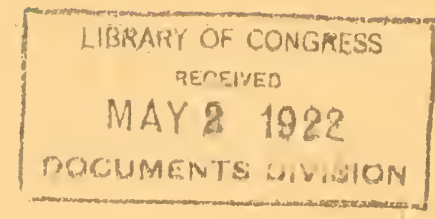

-

LIBRARY OF CONGRESS
RENEVED
MAY 21922
DOKUMENTS LDVULION

$$
\because \vdots
$$




\section{$S B 953$ .485}

\section{UNITED STATES DEPARTMENT OF AGRICUL'CURE}
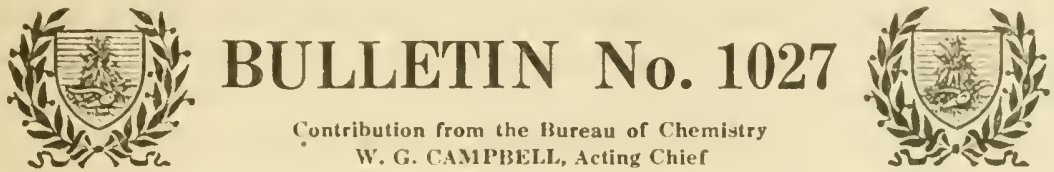

Washington, D. C.

April 17, 1922

\section{POISONOUS METALS ON SPRAYED FRUITS AND VEGETABLES.}

By IF. 1). Lxwch, Assistent Chemist, ('. C. MCDonvell, Chief, Insecticide and Fungicide Laboratory, and J. K. Haywood, Chief, Miscellaneous Division, Burenu of Chemistry: 1. L. QUArNaxce, Entomologist in Charge, Fruit Investigations, B'ureau of Entomology; and M. B. WAITE, Prthologist in Charge, Fruit-Disease Investigations, Bureau of Plant Industry. ${ }^{1}$

CONTENTS.

l’age.

Page.

Purpose of investigation...................

Fiesillts of previolis investigations...........

1

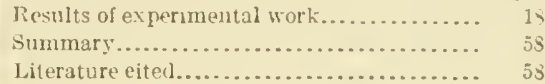

PURPOSE OF INVESTIGATION.

In the spring of 1915 a cooperative study was undertaken in the Enited States Department of Agriculture to ascertain the amounts of arsenic, lead, and copper remaining on fruits and regetables treated with poisonous sprays. The spraying was done under the direction of the Bureau of Entomology and the Bureau of Plant Industry, and the chemical work by the Bureau of Chemistry. The plan was to spray various fruit trees and vegetables according to accepted schedules, and also with excessive amounts of material to determine how much of the metals may be present under adverse conditions. In case the investigation showed that poisonous metals remained on the fruit in amounts which might prove injurious to the consumer, the results would constitute a basis for so changing or regulating the spraying schedules as to eliminate this danger.

\section{RESULTS OF PREVIOUS INVESTIGATIONS.}

Arsenical compounds first appeared as insecticides in the United States $(63)^{2}$ about 1860 , when Paris green was used to check the

1 Credit is due to John G. Fairehili and Wilbur A. Gersdorff for assistanee in the anulytical work reported in this paper.

2 Figures in parentheses refer to Literature Cited, pp. jn to 6.

72632-22-Bull. 102i-1 
ravages of the Colorado potato beetle. In 1872 Le Baron (70) suggested the application of Paris green to fruit trees to combat the spring cankerworm, but Lodeman (75) states that only a few of the most progressive orchardists adopted arsenical spraying against the codling moth until after the establishment of the State agricultural experiment stations resulting from the passage of the Hatch Aet in 1857 .

'The question soon arose as to the possible danger to the consumer from the use of potatoes the vines of which had been treated with a poisonous compound, such as Paris green. One of the first investigators of this subject, Kedzie, in $1872(64)$ and 1875 (65), concluded "that there is but rery little danger of the potato tuber being poisoned so as to endanger the health of the consumer. Arsenic is equally deleterious to the regetable as well as the animal system. If added in dangerous quantity to the plant, the plant dies, no potatoes arc formed." McMurtric (7S) detected no arsenic in potatoes which had been subjected to applications of Paris green.

Lodeman (75) states that London purple was recommended as an insecticide in 1877. Cook (26), who sprayed apple trees on May 25 and June 20,1880 , at the rate of 1 pound of London purple to 100 gallons of water, reported that 100 blossom ends cut from the sprayed trees on August 19 showed no trace of arsenic. He proved also (27) that it took hut a rery small amount of the arsenites to kill potato beetles, currant slugs, and cabbage caterpillars, and discovered that the poison was retained on plants sheltered from rain for 10 to 20 days. He concluded that it was safe to use Paris green or London purple on trees the fruit from which would not be eaten for four or five weeks after the application.

Wheeler (132), in 188s, reported that it was safe in California, where rainless summers prevail, to spray rines with Paris green. When the vines were sprayed with 1 pound of Paris green to 16 gallons of water, "ten times as strong as the sohution recommended for generat use," Rising (114), the State analyst, found only traces of arsenic on the grapes and none in the wine made therefrom.

Objection was offered to the use of arsenicals, on the ground that they frequently caused more or less injury to the foliage. Gillette (58), however, found that "lime added to London purple or Paris green in water greatly lessens the injury that these poisons would otherwise do to foliage." Weed (129) recommended applying insecticides and fungicides together, and Gillette (5S) showed that London purple can be used at least eight or ten times as strong without injury to foliage if applied in common Bordeaux mixture instead of in water. Gillette (59) stated, in 1891 , that a mixture of 1 ounce of Paris green to 100 ounces of flour was the most effectual 
remedy against the cablugere worm, applying "just emough to make at slight show of dust upon the leaves." "These discoveriest were quickly

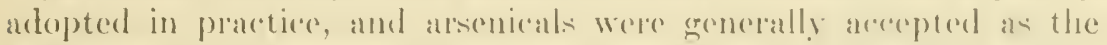
best destrovers of external rhewing insecets.

The most important inseretiedes recommented, other than Paris

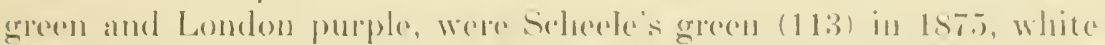
alsonic plus lime $(67)$ in 1S9) and leat alsomate (40) in 1s93. Lntil

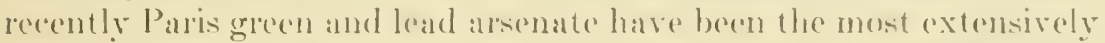
used, but raleium arsenate, now on the marlet, promises to become one of the loading arsenical inserticides.

Tha use of Bordeanx mixture originated in France near the city of Modore. Viticulturists noticed that the vines near the highways, which had been sprinkled with a paste of milk of lime and (opper sulphate to prevent thieving, did not suffer from mildew. Prof. Millardet, in 1852, attributed the beneficial action to copper, and later proposed a mixture of (eopporesulphate, lime, and water, since known as Bordeaux mixture (SS) (S9). The mixtme was immediately alcepted not only in France but in the Luited States, where F. Lamson Soribner (116) was probably the first to publish a formula for it as a result of the work in France. Its use has been extended to the prevention of so many plant diseases that to-day it is perhaps the most important fungicide.

When copper compounds were recommended as funcricides, the question arose as to whether or not spraying with them would leare a langerous amount of copper on the grapes or in the wine.

Perrett (107) stated, in 185i), that there would bo no danger of introlucing copper into wine male from grapes sprayed with copper salts, because the hyllogen sulphid formed during fermentation would precipitate the copper as the insoluble sulphid. Quantin (111), in 1886 , concluded that the reduction of the sulphate of eopper by the forments was suflicient to effect the total climination of the copper in wine, but that aeration of the lees which inclosed the precipitated sulphid of copper should be avoided. Chuard (2:3) announced in 1857 that the copper was present in the must as copper malate, but that it was precipitated during fermentation as the sulphid and tartrate.

In October, 1885, Milladet and Gayon (90) obtained the following amounts of (opper from vines that had heen sprayed with Bordeaux mixture in July:

Freslı leaves (mg. per kgm.).

19. $1-95.5$

Vine branchese (mg. per kgm.)

5. 8

(irape stalks (mg. per kgm.)

15. $0-18.6$

Mares (mg. per kgm.)

11. $1-21.9$

Musts (mg. per liter)

1. $0-2.2$

Wines (mg. per liter), irsu doubtul traces to less than

0. I 
The same authors, in 18S6, report (56) the following amounts of copper at vintage from vines treated with rarious copper mixtures:

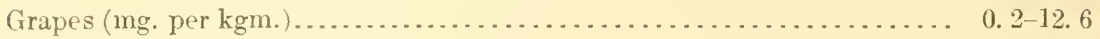

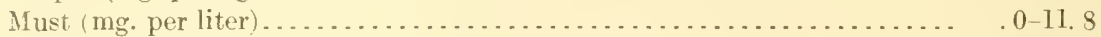

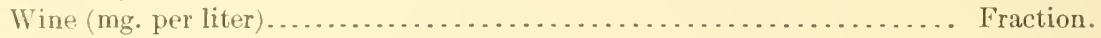

Examination of wines from different places in the southwest of France showed the presence of copper in the following amounts:

First, wines:

White (mg. per liter), less than .......................... 0.01-1. 0

Red (mg. per liter), less than............................. .01-2.8

Second wines (sweet wines) (mg. per liter)...................... . 01-. 3

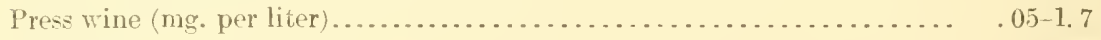
Piquettes:

Normal (mg. per liter) .................................. 00.75

Sour (mg. per liter), less than ............................. . 01- 1.6

They attributed the absence of copper in wine to the action of the fermentation, the tannin and sulphur added to the wines before fermentation favoring the purification of the wine.

Crolas and Raulin (2S) determined the amount of copper in the products of rines that had been treated six weeks to two months before vintage with different preparations containing copper, and found copper in the following amounts:

Grapes (mg. per kgm.) ............................... 1.5- 3. 5

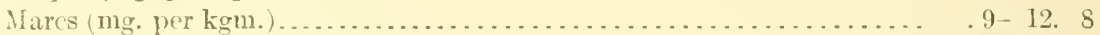

Lees (mg. per $\mathrm{kgm}$. . .................................. 49. 0 . 130. 0

Piquettes (mg. per liter) ................................. . . . 14

Wines $(\mathrm{mg}$. per liter).................................... . . 36

Other investigators who have determined the amount of copper in wine (8) (16) (2.5) (29) (36) (41) (42) (45) (79) (104) (108) (118) (13t) agree that the amount found in every instance was too small to be harmful.

C. L: Penny (105) reported, in 1S89, 2.4 and 6.2 parts of copper per million for grapes that had been sprayed with Bordeaux mixture and 1 to 1.3 parts of copper per million for unsprayed grapes. These amounts were less than those found in some common articles of food. In 1890 (106) grapes so heavily sprayed that "either the appearance or the taste of the fruit would have condemned it on the market" were shown by Penny to contain about 47 parts of copper per million, "less than has been found in some articles of food admitted to be healthful, as beef liver."

In order to determine "whether there is any danger to be apprehended from eating grapes which have been sprayed with the Bordeaux mixture and other copper solutions," Galloway and Fairchild $(47)$ gathered grapes from a plat which had been sprayed eight times with Bordeaux mixture. "The last spraying was made on these 
vines July 30, and between that date and Aucrust 28, the date of harvest, only a few slight rains had fallen. The fruit showed the mixture plainly, more pronouncedly in fact than any treated crapes seen in the market. One kilogrmm of the elusters (2 3 pounds), including the stems, which appeared to have the greater part of the copper, * * * yiclded 0.005 crram (0.077 gruin) of metallic copper." on malysis, about 0.035 grain of copper per pound of grapes.

In September, 1891, the Boird of Health of New York City seized a quantity of grapes some of which had been heavily oversprayed with Bordeaux mixture (46). The following results of analysis of the most heavily sprayed bunches of grapes obtainable from the vineyalds from which the grapes seized had come were reported (128):

(I) The amonut of copper, estimated as metallic copper, found on the berries was very constant in the different samples, averaging $1 / 120$ grain for each pound of fruit (berries and stems).

(2) The amount of copper, estimated as metallic copper, found on the stems varied from 1,90 to 1/1. grain for each pound of fruit (berries and stems), and aroraged 1/30 grain.

(3) If the copper were on the berries in the form of sulphate of copper, each pound of herries would contain ahout $1 / 30$ grain of copper sulphate.

(4) As a matter of fact, copper, when found upon sprayed grapes in New York state. exists, not in the form of a sulphate, but in the form of a carbonate or hydroxid, both of which are not readily soluble and would, therefore, be even less dlangerous than if present in the form of sulphate of copper. Most of the copper found was on the stems, and the rest of the copper was on the outside of the skin of the berries, which most prople do not eat.

(5) The results obtained from estimating by chemical analysis the amount of copper on grapes, which were selected as being the worst sprayed that could be found, therefore, seem to justify the assertion that it is simply an absolute impossil,ility for a person to get enough ropper from eating grapes to exert upon the health any injurious effect whatever.

According to Popenoe and Mason (109), "as much of the fruit (grapes) at the time of ripening showed a greenish-blue discolorition from the deposit of lime and copper, which had been applied twice since a rain had fallen, some persons feared that it might be poisonous." Analysis of those grapes showing the heariest deposit gar re for combined stems and berries $0.0018 \mathrm{~s}$ per cent copper, or 0.52 grain of copper sulphate per pound of grapes. "A short time after this sample was taken a heary shower washed off so much of the deposit that little of the remaining fruit was injured in appearance." Whocler (131) found only slight traces of copper on grapes that had been sprayed with Bordeaux mixture. Alwood (6) reported no copper, or only traces, on grapes that had been sprayed with copper mixtures, and concluded "that these fungicides are perfectly harmless to consumers of the treated fruit." Maynard (St) reported that only" 0.002 per cent of copper oxid was found on grapes which had been so heavily sprayed with Bordeaux as to be badly disfigured und that no 
trace of copper could be foumd on grapes which had been properly sprayed with eopper mixtures. From this it would secm "that even under the most careless use of the copper solutions, no injurious effects need be feared, and that when properly applied there will not be a trace of copper loft upon the fruit at harresting."

In 1892 thr. Enited States Department of Igriculture (9) published the following:

We take the ground that fruit sprayed with the copper compounds in accordance with the directions of the department is harmless. * * * For five years the copper compounds have been used by hunlreds and thousands of fruit growers in elery part of the Inited states, yet in all that time not a single authenticated ease of poisoning, so far as we are aware, has heen hrought to light. * * * Aecepting, theis, 0.5 gram as the maximum amount of copper in any of the forms discussed that may with safety he daily alsorleel, * * * that grapes sprayed intelligently rarely contain more than 5 milligrams $(0.005$ gram) of copper per kilogram, the average being from 21 to 3 milligrams per kilogran, * * * an adult may eat from 300 to 500 pounds of sprayed trapes per day without fear of ill effects from the copper. This shows how ridiculously absurd are the statements that fruits properly sprayed with the Bordeaux mixture or any other copper compound are poisonous.

According to numerous analyses, wheat may contain from 4 to 10 milligrams of copper per kilogram. * * * We lo not see how any foreign conntry can logically object to American fruits on the ground that they co.ttain copper without also objecting to wheat.

Wheat, however, does not contain anything like as much copper as some other foods and drinks. Beef liver and sheep liver, according to reliable and repeated analyses, coltain, respectively, from $5 f i$ to 58 and 35 to 41 milligrams of metallic copper per kilogran of fresh substance, while in chocolate the enormons amount of 125 milligrams to the kilogram has been found. In conclusion, it is o I necessary to call attention to one other matter to show how unjust and discriminating it woukd be to condemn American fruits on the ground that they contain copper in unwholesome quantities. Analyses of vegetables that have been regreened by the copper process show that they nay contain from two to sixty times as much of the metal as sprayed grapes.

In this ronnection the presence of copper reported in various foodstuffs in the following amounts is of interest:

From 4 to 10 milligrams per kilogram in wheat $\langle 43)$; 56 to 58 milligrams per kilogram in beef liver (105): ahout 40 milligrams per kilogram in sheep liver (35) (100); from 5.6 to 20.8 (4.1) and from 5 to 125 (31) milligrams per kilogram in chocolate; from 11.2 to 29.2 (41) and from 9 to 40 (31) milligrams per kilogram in cocoa; from 35 to 250 milligrams per kilogram in cocoa shells (:31). Instances are cited (77) where as much as 2,0 milligrams of copper per kilo was found in French peas that had been subjecterl to the regreening process. Tschirch stated (127) that copper is widely distributed in plant and animal hodies, always, howevor, in small amounts; that it enters the animal bollies through food and dust; l,ut that the presence of copper in the bodies of man and other higher animals is not to be considered as "normal." He stated further that plants absorb only small amounts of copper from the ground; that no danger to health need the cxpeeted from the consumption of wine from sprayed grapes or of potatees from sprayed tields, and that even the nust of coppered grapes may be eaten and the skins (containing 0.006 gram of copper per kilo) used as fodder; that spraying with copper against fungous diseases might be continued without fear of harm; that only very small quantities of the copper compounds entering the mouth 
are taken up by the blood, and poisoning can occur only if the necessary quantity enters the circulation; and that to forbid copper in foods and drinks is to forbid those plants which take it up from the grouml, and also to designate the use of bread and chocolate as dangerous to the health.

Lehmam reported the following amounts of eopper per kilogram in various plant and animal substances: In wheat, 7.5 milligrans; in cherries, 1.5 milligrams; in pears, 0.5 milligram; and in beef liver, from 6.4 to 59 milligrams $(71)(73)$. He stated $(72)$ that the species of the plant lad far less influence than the quantity of the eopper in the soil on the amount taken up by the plant.

In 1891 objections to the use of American apples because of the presence on them of arsenic were made in certain Britislı journals. However, Maynard (85), Munson (97), and Fletehel (3S) proved that the objection had no basis in fact, and later (10) (103) (126) it became apparent that such objections to sprayed fruit in England were neither very general nor rery deep-seated.

Table 1 shows the amount of arsenic and copper found by R. C. Kedzie (66) on fruit sprayed with Bordeaur mixture and London purple in 1892 and 1893.

TABLE 1.-Arsenic and copper on fruit sprayed in 1892 and 1893 with Bordeaux mixture and London purple (Kedzie).

\begin{tabular}{|c|c|c|c|c|c|}
\hline Fruit. & Date sprayed. & $\begin{array}{c}\text { Date } \\
\text { picked. }\end{array}$ & Spray used. & $\mathrm{As}_{2} \mathrm{O}_{3}$. & $\mathrm{CuSO}_{4} .5 \mathrm{H}_{3} \mathrm{O}$. \\
\hline Strowberries & 1592 & 1592 & & Grains & per pound. \\
\hline shak verties... & June $15,23 . .$. & June $2 t$ & don purple, 200 gallons water. & $0.04+0$ & $4.5,0$ \\
\hline Red cherries. & .....do...... & ...do..... & $\begin{array}{l}2-11-32 \text { Bordeaux, } 1 \text { pound } \\
\text { London purple, } 200 \text { gallons } \\
\text { water. }\end{array}$ & .0298 & 1.821 \\
\hline net creats.. & 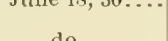 & Jury & $\begin{array}{l}\text { 6-4-32 Bordeaux, I pound Lou- } \\
\text { don purple, } 200 \text { gallons water. }\end{array}$ & .0382 & .390 \\
\hline Whitc cherries.... & June $30 \ldots$ & $\begin{array}{l}\text {...do..... } \\
\text { July } 1\end{array}$ & $\begin{array}{l}2-1 \frac{1}{2}-32 \text { Bordeaux, } 1 \text { pound } \\
\text { London purple, } 200 \text { gallons } \\
\text { water. } \\
6-4-32 \text { Bordcaux, } 1 \text { pound Lon- }\end{array}$ & .0250 & .252 \\
\hline Red currants.. & Iay 25, June & July 8 & $\begin{array}{l}\text { don purple, } 200 \text { gallons water. } \\
\text { London purple.................. }\end{array}$ & .0503 & \\
\hline Raspberries... & $\begin{array}{c}\text { June } 6, \quad 28, \\
\text { July s. }\end{array}$ & July 20 & $\begin{array}{l}\text { 2-12-32 Bordeaux, } 1 \text { pound } \\
\text { London purple, } 200 \text { gallons } \\
\text { water. }\end{array}$ & .0098 & .028 \\
\hline Gooseberries.... & June is, 29 , & Aug. 2 & 6-4-32 Bordeaux, 1 pound Lon- & .0233 & .601 \\
\hline $\begin{array}{l}\text { Do........ } \\
\text { Pears........ }\end{array}$ & $\begin{array}{l}\text { June } 15, \mathrm{Juily} \\
7,21, \text { Lug. } 7 \text {. }\end{array}$ & Sept. 6 & ....do & $\begin{array}{l}.0372 \\
.0058\end{array}$ & $\begin{array}{l}.362 \\
.0738\end{array}$ \\
\hline Do. & May 159. June & & No London purple, 2-2-32 Bor- & & .100 \\
\hline Russian cherries.. & $\begin{array}{l}\text { 12, July I0. } \\
\text { May I4, June } \\
\text { 10, 15, July } \\
15 .\end{array}$ & & $\begin{array}{l}\text { deaux. } \\
\text { First } 3 \text { dates, } 2-2-32 \text { Bordeaux; } \\
\text { last date, "eanceleste." }\end{array}$ & & .147 \\
\hline Plums .. & & & ....do.. & & .200 \\
\hline
\end{tabular}

The skins from 1 pound of the sprayed pears gave 0.106 grain and the flesh gave 0.071 grain of copper sulphate, "showing that while most of the copper salt adheres to the surface, a portion finds its way into the body of the fruits." 
In 1893 Daris (30) reported the determinations of arsenic on celery that had been sprayed with Paris green at the rate of 1 pound to 175 gallons of water. The results, obtained on the celery washed without separating the stalks and prepared as for market, were as follows: Sprayed once, 0.0244 grain of arsenious oxid per pound of celery; sprayed twice, 0.0368 grain of arsenious oxid per pound of celery.

In 1893 Beach reported (12) the presence of from 0.00042 to 0.001 per cent of copper in celery that had been sprayed with Bordeaux or ammoniacal copper carbonate solution, and 0.00081 per cent in unsprayed celery, concluding that "these investigations show that when this sprayed celery was stripped and ready for market the sprayed plants were no more poisonous than the unsprayed."

In 1894 Kinney (68) stated that the skins and stems of pears which had been sprayed five times with Bordeaux mixture (6 pounds of copper sulphate, 4 pounds of lime, and 22 gallons of water), and upon which the spray was still visible at harrest contained only 0.016 grain of copper oxid per pear, for which reason no serious objection to this treatment could be raised from a hygienic standpoint.

In 1894 Garman reported (49) that the skins and ends of six apples from a tree that had been sprayed once with London purple and five times with Paris green at the rate of 1 pound to 160 gallons of water showed on analysis no arsenic and only an unweighable amount of copper. The flesh and cores of these apples gave no reaction for arsenic or copper. He reporter also (50) that cured tobacco which had been spraved with arsenites, at the rate of 1 pound to 160 gallons of water, gave on analysis 0.077 grain of arsenious oxid and $0.0+2$ grain of copper oxid per pound with one spraying with Paris green; $0.133,0.259$, and 0.329 grain of arsenious oxid and $0.126,0.210$, and 0.322 grain of copper oxid per pound with two sprayings with Paris green: and 0.245 grain of arsenious oxid per pound with two sprayings with London purple. Later (1904) this author stated (51) that arsenites such as Paris green can be used on cabbage without learing a trace sufficient for recognition by the chemist. In 1901, cabbages which had been spraved with Paris green or lead arsenate showed on analysis "traces of poison present." In 1902, and again in 1903, sprayed cabbages were analyzed, but the chemist "was unable to find a trace of poison present."

In 1897 Teyxeira (123) found from 20 to 50 milligrams of copper in 1 kilogram of juice from tomatoes that had been sprayed with copper sulphate, and none after treatment with Bordeaux, unless the skin was cracked. He stated that the copper sulphate penetrates the skin into the flesh, but that the copper-lime mixture does not. 
In 1898 Hoffmann reported (62) the presence of from 0.0046 to 0.0128 gram of copper per liter in wines, but failed to give the history of the samples. Later he reported 0.00096 and 0.0058 gram of copper per liter in wine, 0.0025 and 0.0056 gram of copper per liter in must, 0.0027 and 0.0045 gram of copper per liter in gralpe-skin wine, and 0.053 gram of copper per 100 grams in the grape skins.

Selby found (117) 0.0004 gram of copper per 100 grams of grapes to be the maximum amount on the samples he examined. To show that sprayed grapes can be safely used for making wine he cites Krüger (69), "that in the different musts different amounts of copper, at the beginning of fermentation, or just before the begimning, enter into an insoluble and consequently an inert (copper) compound, in consequence of the presence of greater or less amounts of organic acids. From this condition it is likely that the copper of the must, arising from the spraying of the grapes, is without any importance for the wine.'

Gibbs and James (57) reported that 292 of 352 samples of wine examined contained no arsenic, $5 \mathrm{~s}$ contained from a trace to 1 part in $8,000,000,1$ contained 1 part in 5,000,000, and another 1 part in $2,500,000$. They stated also that of 200 samples of wine examined by C.S. Ash the three highest in arsenic contained 1 part in $6,000,000$, 1 part in $8,000,000$, and 1 part in $14,000,000$. "The most probable sources of the major part of that found are arsenical sprays when used upon the rines, sulphur burned for the purpose of sulphuring the wines and receptacles, and perhaps to some extent the lead shot used in cleaning the bottles." A sample of sulphur from a California winery was found to contain arsenic in the proportion of 1 part in 5,000 . It is not stated whether these wines were the product of sprayed vines.

In 1906 Roger Marès (\$2) reported that he found no trace of arsenic in wine from a vine treated a month before grape gathering with a copper-arsenical mixture, and he accordingly continued to recommend this combined mixture as a spray for the vines in Algiers. The same year Von der Heide (61) reported the results shown in Table 2 on products of vines that had been sprayed with lead arsenate.

TABLE 2.-Metals on products of vines sprayed with lead arsenate (Ton der Heide).

\begin{tabular}{|c|c|c|c|}
\hline & Arsenic. & Lead. & Copper. \\
\hline 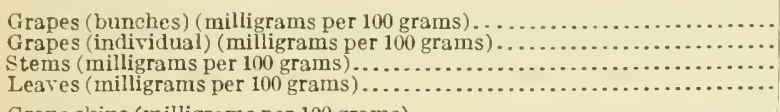 & $\begin{array}{r}0.3 \\
.2 \\
7.0 \\
16.0 \\
.7\end{array}$ & $\begin{array}{r}0.7 \\
.3 \\
10.6 \\
48.0 \\
1.4\end{array}$ & ( \\
\hline 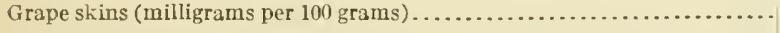 & .6 & .8 & \\
\hline 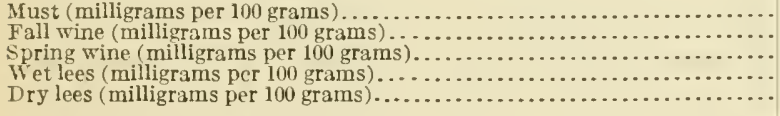 & $\begin{array}{r}.3 \\
.2 \\
.1 \\
3.0 \\
12.9\end{array}$ & $\begin{array}{r}.8 \\
.6 \\
.2 \\
4.8 \\
20.7\end{array}$ & $\begin{array}{l}\ldots \ldots \ldots \\
\ldots \ldots \\
\ldots \ldots \\
\ldots \ldots \\
\cdots \ldots\end{array}$ \\
\hline
\end{tabular}


The German Imperial Health Commission was opposed to the use of lead arsenate in the spraying of grapes because arsenic and lead were found in the wine.

In 1907 Szameitat (121) (122) reported the following results of analyses of musts, wines, and grapes from rines sprayed with arsenic compounds: From a trape to 0.9 milligram of arsenic in 300 grams of grapes; none to 0.14 milligram of arsenic in 300 cubic centimeters of must; none or only a trace in 300 cubic centimeters of wine. Of 38 samples of German wine examined, 24 showed small amounts of arsenic, the largest amount being 0.05 milligram in 100 cubic centimeters of wine. The source of arsenic was not identified.

The use of arsenic compounds for the destruetion of insects that derastated vines haring become more or less general in central France, in spite of the fact that the French ordinance of 1846 prohibited the use of arsenic for the destruction of insects, the question arose as to the danger of such use.

In 1907 Bertin-Sans and $\operatorname{Ros}$ (11), who were among the first in France to publish an answer to this question, found less than 0.001 milligram of arsenic in 145 grams of unripe grapes gathered one month after spraying with sodium arsenate, and $0.002,0.001,0.030$, and 0.040 milligram of arsenic per liter in wine from arsenical treated rines. These investigators stated that as sheep and cows were not admitted to the splayed rines and were not fed the sprayed foliage until after harvest there was no danger to these animals, but that rabbits and snails might be poisoned by eating sprayed foliage, and, since subils can tolerate a faily large amount of arsenic, persons should refrain from eating them during the spraying season. As lead is a cumulative poison, it was considered more prudent to use arsenicals other than lead arsenate, although no data existed to show that there was danger in the use of lead arsenate as an insecticide. BertinSans and Ros believed that the chief danger in the use of arsenieals arose from mistakes due to carelessness and that if suitable regulations were enforeed no danger was to be feared. Since the ordinance of 1846 was a dead letter, it seemed to them much better to have the arsenicals handled under definite regulations. In 1908 (15) they stated that as they had found only traees of arsenic in wine from rines sprayed with arsenicals, there was no ground for the fear that the arsenic would pass into the wine if the rines had been sprayed before the grapes were in bloom.

In 1909 Truelle (125) (126) concluded that the adrantages of arsenical spraying were so great that its use under regulation should be authorized in France.

Cazeneure (21), thinking that the use of arsenical insecticides was a serious menace to the public health, asked (1908) for the strict enforcement of the ordinance of 1846. Riche (112) and Gautier (52), 
on the other hand, believed that the use of arsenicals, with the exception of lead arsenate, should be permitted in agriculture, but only under proper regulation.

In 1909, a committee appointed by the Academy of Medicine (1) (21) (112) to study this question recommended (96) the strict enforcement of the ordinance, thus causing a very lively discussion. Teiss (130), believing that the committee did not have sufficient eridence to substantiate its recommendation, proposed a medical investigation, this proposal being adopted (2) and sent to the minister of the interior as the adrice of the academy. A rear later the academy asked (32) that a new inrestigation, essentially medical, be carried on for two year's, and, to aroid accidents, recommended strict regulations in the use of arsenicals and the complete exclusion of lead arsenate. The direction of the inrestigation was to be intrusted to the councils of hygiene and the sanitary commissions of each department, after consultation with the professors of agriculture (33). In 1911, dissatisfied with the lack of enforcement of its suggestions, the academy decided (34) to recall to the public powers the conditions they had recommended as to the use of arsenicals in agriculture. Malry, undersecretary of state, stated (80) that since the inrestigation conducted by the minister of the interior had disclosed no accident, either among the workers who handled the arsenicals or among the consumers, to prohibit the use of lead arsenate would be to impose useless annoyances on merchants and riticulturists. In 1913 the minister of the interior submitted to the Academy of Medicine a draft of a decree carrying modifications of the ordinance of 1846 , permitting the use of insoluble arsenicals in agriculture (3).

After much discussion (5) (22) (53) (54) (76), articles 9 and 10 of the draft, authorizing the use of arsenicals in agriculture under specified regulations, were adopted by the academy (4) (5), with the recommendation that the order of the minister of agriculture dealing with the precautions to be taken in their use should apply to all arsenicals and not merely to lead arsenate, "and article 11, which prohibited the sale and use of soluble arsenic salts, was amended to permit their sale when "denatured" (5). The academy also roted (5) that the public powers be requested to take every means to inform the public of these regulations and to impose penalties for their infraction, and that the Gorernment be requested to encourage researches to find substitutes for arsenicals. The French decree authorizing the use of insoluble arsenicals in agriculture, under regulation (81), and the minister of agriculture's instructions for the sale and use of these arsenical compounds were published in 1916 (86). The sale and use of soluble arsenicals as insecticides were prohibited.

Breteau (17) analyzed 15 samples of wine from rines sprayed with arsenicals, finding from none to 0.04 milligram of arsenic per liter in 
12 of the samples and $0.1,0.1$, and 0.2 milligram of arsenic per liter in the other three. Ho attributed the higher content of arsenic in the last three samples to the fact that the wines had been sulphured. If, as held by Gautier and Clausmam (5.5), a normal wine contains about 0.01 milligram of arsenic, he felt that the arsenical treatment of rines will introdure into the wine less than 0.03 milligram of arsenic per liter. Mestrezat (S7) considered that the only danger from the use in viticulture of alsenical insecticicles oceurs when they are placed near other substances which resemble them so closely as to be easily mistaken for them. In 1906 Forbes (39) reported 36.6 and 32.9 parts of arsenious oxid per million in peelings of apples sprayed the prexeding day with lead arsenate and 40.1 parts of arsenious oxid per million in peelings of apples gathered two months after being sprayed heavily with lead arsonate. He considered that lead arsenate could be substituted for the more common insecticide sprars if discretion were exercised in its use. In 1910 Günther (60) reported the results given in Table 3 on fruits that had been sprayed once with a mixture containing 300 grams of sodium arsenite and 42.5 grams of lead acetate per 100 liters.

TABLE 3. - Residue on fruils sprayed onee with mixture containing 300 grams of sodium arsente and 45.5 grams of lead aeslate per 100 liters (Günther).

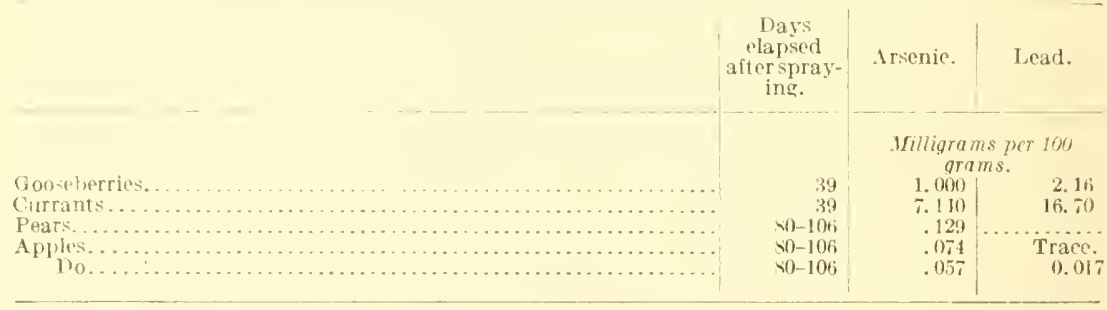

He reported the results given in Table $t$ on fruits dusted once with a mixture consisting of 2 parts of freshly slaked lime, 4 parts of sulphur, and 1 part of Paris green.

TABLE 4.- Residue on frwits dusted once with'a mixture consisting of ? parts of freshly slnked lime, 4 parts of sulphur, and 1 part of Paris grecn (Cünther).

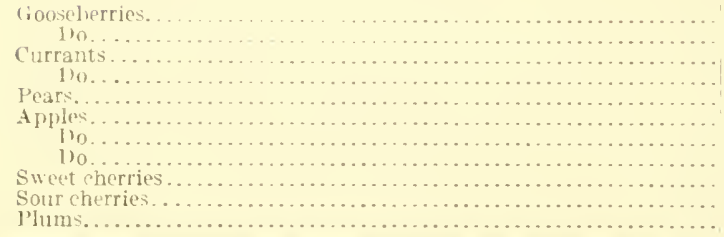

\begin{tabular}{|c|c|c|}
\hline $\begin{array}{l}\text { Days } \\
\text { clapsed } \\
\text { after dust- } \\
\text { ing }\end{array}$ & Arsenie. & Copper. \\
\hline & \multicolumn{2}{|c|}{$\begin{array}{c}\text { Milligrams per } 100 \\
\text { arams. }\end{array}$} \\
\hline 39 & 0.8300 & 0.560 \\
\hline 39 & 2. 1200 & .930 \\
\hline 39 & 1. 6100 & $\cdots=0$ \\
\hline so-10n & $\begin{array}{r}.5300 \\
.0720\end{array}$ & .240 \\
\hline $80-106$ & .0120 & .067 \\
\hline $80-106$ & .0084 & .095 \\
\hline$\times(0-10 k$ & .0420 & .011 \\
\hline 24 & .2000 & .160 \\
\hline 24 & .3200 & .250 \\
\hline & & Trace. \\
\hline
\end{tabular}


In 1910 Bedini (13) reported from 0.2 to 0.4 milligram of arsenious oxid per kilogram in the skins of pears that lad been sprayed with arsenate of iron, and only a trace of arsenic in the pulp. The same year Porchet (110) reported that pears sprayed with lead arsenate contained as much as 0.3 milligram of arsenious oxid per kilogram in both the pulp and the skin; that the skins of unsprayed pears contained 0.035 milligram of arsenious oxid per kilogram of fruit; that sprayed grapes eontained traces of arsenic, apparently the same in the interior as on the exterior of the fruit, the highest amount obtained being 0.2 milligram per kilogram of grapes; and that the traces of arsenic passed from the grapes into the must, but that the arsenie was precipitated as sulphid during the fermentation. Chuard (24) also found that the arsenic in the must was precipitated as sulphid during the fermentation.

Fetel (37), in 1910, reported that 10 samples of grapes bought on the market in Algeria on August $\$$ and 25 , September 1 and 19, and October 3 contained an average of 0.035 milligram of arsenie per kilogram, while unsprayed grapes, eollected on dugust $S$ and September 1 and 8 , contained no arsenic. Grapes sprayed twice before blossoming, with a Bordeaux-sodium-arsenate mixture, and gathered on August 10 and 25 and September 5 and 22, contained, respectively, $0.185,0.083,0.074$, and 0.074 milligram of arsenie per kilogram. Grapes sprayed twice before flowering with arsenious acid and on July 24 with Bordeaux-arsenious-acid mixtures, and gathered on July 24 before and after this last spraying, on August 22, and on September 15, contained, respeetively, 0.056, $0.467,0.149$, and 0.112 milligram of arsenie per kilogram.

In 1909 and 1910 Brioux and Griffon (18) found 0.001, 0.001, and 0.004 milligram of arsenie per kilogram in three lots of pears that had been sprayed with a Bordeaux-lead-arsenate mixture. They also reported that, although apples which had been sprayed with lead arsenate on June $S$ and June 22, 1910, contained when examined in July 1.3 milligrams of arsenic and 14.2 milligrams of lead per kilogram, yet in September, at harvest time, the apples and the cider contained no lead and only traces of arsenic.

Moreau and Vinet (92), in 1910, reported that grapes sprayed with lead arsenate on May 27 and June 6 contained, respectively, on Jume 22 and September 14 , about 2 and 0.28 milligrams of lead arsenate per bunch, and that 165 grams of moist lees contained 1.38 milligrams of lead arsenate, but that the wines contained no lead or arsenic. They found (93) that only 1 per cent of the lead arsenate which they had applied on May 31 was retained by the grapes, 0.58 milligram per bunch, and that with the development of the grapes a second spraying was necessary on June 14 to conteol the first generation of the eochylis larva. They also found that a spraying on August 6 to control the 
second generation of this insect adhered mostly to the stems. They concluded from other experiments (94) that, since grapes sprayed twice with lead arsenate before flowering, on May 31 and June 14, showed no lead or arsenic at harvest time, October 15 , there would be no danger in consuming grapes sprayed so early, but that, since grapes sprayed after the flowering period, on Lugust 6, showed 0.40 milligram of lead arsenate per 100 grams of grapes at harrest time, October 27, there might be danger in consuming grapes sprayed so late in the seison. They reported further (95) that wines from rines treated before the flowering period with lead arsenate could be consumed without langer, since only faint traces of lead and arscnic were found in wines from such vines and that the lead and arsenic were eliminated during the process of the making of the wine, being found principally in the marc and in small amounts in the lees.

In 1911 Ampola and Tommasi (7) stated that foodstuffs derired from plants treated with arsenical compounds always contain arsenic, usually in traces, but sometimes as much as 2 milligrams or even more per kilogram in fruits and 1.5 milligrams per liter in wine, amounts greater than that allowed by the Royal Commission on Arsenical Poisoning in England (11) (115).

In 1912 Muttelet and Touplain (99) reported that the grapes, marcs, wines, piquettes, and lees which ame from rines trented with lead arsenate contained about the same amount of arsenic as wis found in the products from rines not treated, that the wines and piquettes contained no lead, but that the lees in certain cases contained an approciable quantity of lead, in which cases there was danger in the consumption of wine or piquette before the deposition of the lees, and that grapes sometimes retained on their surface a quantity of lead which rendered dangerous their consumption in a natural state. The same year Carles and Barthe (20) reported that the wines from rines sprayed before the formation of the fruit with execss of lead arsenate contained only negligible traces of arsenic and leat and that those from vines normally treated with lead arsenate contained neither arsenic nor lead, but that the lees contained 0.002s and $0.0001 \mathrm{gram}$ of arsenic per liter and traces of lead. Aecording to Mathieu (S3), unsprayed grapes and wines made from them contain only traces of areenic, grapes from rines sprayed with arsenicals before flowering contain not more than 0.0 .3 milligram of arsenic per kilogram, eren in a dry year, red wine made from grapes treated with arsenicals in a vear of abundant rain contains only a little more arsenic than wine made from unsprayed grapes, the amount being less than 0.06 milligram per liter, and part of the arsenic in the grapes remains in the mare in making red wines, which wines, however, should not contain more than 0.05 milligram per liter. In 1914 Garino (18) stated that the amounts of arsenic met in analyses of 
wines from grapes subjected to cupro-arsenical treatment are rery small, being less than the minimum therapeutic dose of 5 milligrams, and therefore need cause no alarm.

In 1913 Spallino (120) found in three samples of snuff $0.16,0.40$, and 0.34 milligram of arsenic per 100 grams of dried snuff, and in four samples of smoking tobacco $0.08,1.02,0.30$, and 0.64 milligrams of arsenic per 100 grams of dry tobacco.

Sonntag (119), in 1914, concluded from the results he obtained on ripe fruits and leaves treated in 1907 and 1908 with arsenical mixtures that the arsenical sprays or dusts applied to fruit trees and bushes adhere to the fruits and are retained by them for a long time, in many cases even until the ripening of the fruit.

O Gara (101) stated that the skin of apples sprayed with lead arsenate may occasionally absorb some arsenic. In such cases the skin is likely to derelop red or black spots. Analysis of such spotted apple skins showed the presence of fractions of a milligram of arsenic. Woods (133) reported that apples sprayed with lead arsenate during the first week in August, 1913, carried upon their surface, about two months after spraying, from one-eighth to one-third milligram of lead arsenate per apple. He concludes that "midsummer spraying with lead arsenate is an effective way of combating the browntail moth," and "the amount of.arsenic or of lead that will remain at harrest upon the apples that are sprayed in midsummer with arsenate of lead is so slight as to hare no practical bearing."

In 1916 Trofimenko and Obiedoff (124) reported that grapes treated with wet arsenical mixtures under conditions most favorable for the continuance of the arsenical salts, both on the grapes and in the must, yielded unobjectionable wines. No arsenic was found in white wine and only 0.0002 gram of arsenious oxid per liter in red wine. The lees might be used for extracting the tartar, washing being enough to remove the arsenates. Muttelet (98) stated that the wine and piquette from vines treated with copper sulphate and lead arsenate, even after the formation of the grapes, contained no lead or copper, and no more than traces of arsenic. The pomace wine contained no lead, traces of copper, and 5 milligrams of arsenic per hectoliter. The lees contained 500 milligrams of lead, 10 milligrams of arsenic, and traces of copper per liter. The air-dried marc contained 200 milligrams of lead, 0.1 milligram of arsenic, and traces of copper per kilogran.

Liberi, Cusmano, Marsiglia, and Zay (74) found copper in the fruit of tomatoes in amounts varying from 0.14 to 2.10 milligrams per kilogram of juice and pulp, and from 3.S to 19.5 milligrams per kilogram of dry matter. The soils upon which the tomatoes were grown contained copper up to 110 milligrams per kilogram. These investigator's stated that the spraying with copper mixtures had no 
cffect upon the copper content of the tomatoes. It appeared that the copper found in the tomatoes came from the soil. whence the plants assimilated it in different proportions, according to the nature of the soil or under the influence of other factors.

In 1917 Carles (19) stated that copper occurs in small amounts in agricultural products and in larger amounts in calf liser and beef liver. () Kane, Hadley, and Osgood (102) reported the following amounts of arsenic (calculated as $\mathrm{As}_{2} \mathrm{O}_{3}$ ) on fruits and regetables that had been sprayed with dry lead arsenate equiralent to 3 pounds of lead arsenate paste to 50 gallons of water: Apples picked at intervals ranging from 3 to 91 , days after spraying, 0.08 to 0.75 milligram per apple when picked carefully, 0.02 to 0.50 milligram when picked in the ordinary way, 0.10 to 0.21 milligram when picked with cotton gloves, and 0.08 to 0.18 milligram when picked with cotton gloves and wiped; strawberries picked 2 and 6 days after spraying, from 8.6 to 34.2 milligrams per quart; currants picked 3 , 6 , and 8 days after spraying, from 6.8 to 10.2 milligrams per quart; backheries picked on the day they were sprayed, from 3.8 to 11.2 nilligrams per quart; cabbage gathered 2 and 8 days after spraying, from 43.5 to 51.4 milligrams per head: and lettuee gathered 1 and 6 days after spraying, from 1.6 to 10.6 milligrams per hoad. The maximum amount of lead arsenate spray that would adhere to an apple, when sprayed directly, was found to be an amount equiralent to 4 milligrams of arsenious oxid. Such fruit gave evidence of spray material on its surface.

\section{EXPERIMENTAL WORK.}

The inrestigation conducted hy the L'nited States Department of Agrieulture included experiments on peaches, cherries, plums, apples, pears, grapes, eranberries, tomatoes, celery, and cucumbers. The spraying schedules are shown in Tables 5 to 14.

\section{METHODS OF ANALYSIS.}

The following methods of analysis were employed:

of the whole fruit and pulp, dry 200 to 300 grams of sample on the steam 1 ath in glass dishes, and report loss as "loss on drying." (For the determinations on the skins, use parings from 4 apples; for the calyx and stem end determinations, use 12 apples and rorrsponding amounts in the case of other fruits.) Transfer the dried residues to easseroles and add 100 to 200 ce. nitric ar.id. Heat the mixture, if necessary, to start action, and when violent action is over (antiously add 20 e $(\cdot$ sulphuric arid. Heat on hot plate, removing at intervals to add small amounts ( 3 to 5 c'c.) of nitric acid (do not allow the solution to lecome 1 lark $\mathrm{k}$ ), and when the oxidation is complete evaporate until sulphurie aril fumes are given off. Cool, dilute with water, and again evaporate to sulphuric arid fumes. Cool, dilute with al out $100 \mathrm{cc}$. of 50 per cent alcohol, and let stand over night. Filter and wash with 80 per rent alcohol. Save sulphate prexipitate for lead deternination. The copper and arsenic are determined in the filtrate. Evajorate the filtrate to small volume on stran 1 ath to remove alcohol. Make to volume. 
Arsenic.-Determine arsenic in an aliquot by the Gutzeit method (Bur. Chem. ('irc. 102), modified as follows: The aliquot should contain less than $0.08 \mathrm{mg}$. arsenic. Dilute to $50 \mathrm{cc}$. Add strong sulphuric acid so as to have $10 \mathrm{cc}$. present Add 1 gram sodium chlorid to the aliquot in a small Erlenmeyer flask, heat on steam hath to alout $90^{\circ} \mathrm{C}$., then add $1 \mathrm{cc}$. of a stannous chlorid solution containing 0.5 gram dissolved in hydrochloric acid, and leave on steam loath for about 5 ninutes (temperature near $90^{\circ}$ ( .). Remove from steam bath, transfer to the 4-ounce generating bottle, dilute to $100 \mathrm{cc}$, and cool to room temperature. This generating lottle is connected by a rubler stopper with an upright tuhe $8 \mathrm{~cm}$. long, $1 \mathrm{~cm}$. diameter, containing lead acetate paper. This tube is connerted by a rubber stopper with a similar tube containing cotton moistened with 5 per cent lead acetate solution. Connected by a rubler stopper with this tube is a capillary tuhe $3 \mathrm{~mm}$. in diameter, $12 \mathrm{~cm}$. in length, carrying the strip of mercuric bromid paper. Prepare these strips as follows: Cut heavy, closetextured drafting paper into strips $2 \mathrm{~mm}$. by $12 \mathrm{~cm}$.; then soak them for an hour in 5 per cent alcoholic mercuric bromid solution, take out, rapidly squeeze off excess of solution, separate on glass rods, and allow to dry. Place three pieces of stick zine (about 10 grams) in the generating bottle and join it immediately to the apparatus tubes. Allow the determination to run for $1 \frac{1}{2}$ hours, keeping the temperature down to room temperature by placing the bottle in cool water. From standards plot a curve showing milligrams of arsenic to millimeters in length. As high as 0.08 milligram of arsenic can be read on a paper. Determine the larger quantities of arsenic by passing the arsine into a mercuric chlorid solution and either weigh the mercurous chlorid or titrate the arsenious oxid. (Bur. Chem. Circ. 102, p. 5.)

Copper.-Introduce an aliquot into a $100 \mathrm{cc}$. Erlenmeyer flask. Neutralize the acid with ammonia, add 2 to $3 \mathrm{cc}$. hydrochloric acid for every $50 \mathrm{cc}$. of solution, and saturate the solution with hydrogen sulplid. Stopper flask and let stand over night. Filter off the copper sulphid and wash with hydrogen sulphid water. Place the filter paper containing the copper sulphid in a $50 \mathrm{cc}$. casserole, burn off the paper, dissolve residue in $5 \mathrm{cc}$. (1:1) nitric acid, evaporate to dryness, add water and 1 drop ammonia, make faintly acid with acetic acid, and add a few drops of a 2 per cent potassium ferrocyanide solution. Compare with standards.

Lead.-Dissolve the sulphate precipitate, previously referred to, in hot 10 per cent ammonium acetate solution, add 2 cc. ( 0.1 per cent solution) gum arabic, and make to volume with hydrogen sulphid water in $50 \mathrm{cc}$. (or $100 \mathrm{cc}$.) Nessler tubes. Compare the tubes thus prepared with standards made up similarly with gum arabic, anmonium acetate, known amounts of lead, and hydrogen sulphid water.

Where copper alone is to be determined, heat the dried sample cantiously over a Bunsen burner and finally ash at the mouth of the electric-muffle furnace. Add 5 ce. (1:1) nitric acid to the ash, evaporate almost to dryness on steam lath, dilute, and make alkaline with ammonia. Filter off precipitate and wash. Dissolve precipitate, reprecipitate with ammonia, and wash. Evaporate the united filtrates to dryness, add water and one drop ammonia, make slightly acid with acetic acid, and add a few drops 2 per cent potassium ferrocyanide solution. Compare with standards.

The presence of between 0.02 and 0.24 milligram of copper can be determined by this method. Larger amounts may be determined by taking an aliquot, by comparing in ammoniacal solutions, or by electrolysis.

The presence of from 0.02 to 0.24 milligram of lead can be read in the 50 cubic centimeter Nessler tubes, larger amounts by using 100 cubie centimeter Nessler tubes or by taking a smaller aliquot. 
The whole and pulp of apples were fumed in 7 -inch casscroles and the skins were fumed in 5-inch casseroles, all being transferred to 4 -inch casseroles bafore final fuming. Casseroles were covered until final fuming.

\section{RESULTS OF EXPERIMENTAL WORK.}

The rults of the chemical analyses appear in Tables 5 to 15 , inclusive.

TABLE 5.-AIrsenic and lead remaining on sprayed peaches at picking time.

\begin{tabular}{|c|c|c|c|c|c|c|c|c|c|c|c|}
\hline \multirow[b]{2}{*}{$\begin{array}{l}\text { Sam- } \\
\text { ple } \\
\text { No. }\end{array}$} & \multirow[b]{2}{*}{ Spray material used.1 } & \multirow[b]{2}{*}{$\begin{array}{c}\text { Date } \\
\text { sprayed. }\end{array}$} & \multirow{2}{*}{$\begin{array}{l}\text { Determi- } \\
\text { nations } \\
\text { madeon. }\end{array}$} & \multicolumn{2}{|c|}{ Arsenie(As). } & \multicolumn{2}{|c|}{ Lead (Pb). } & \multirow[b]{2}{*}{ 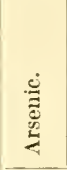 } & \multirow[b]{2}{*}{ 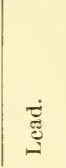 } & \multirow{2}{*}{ 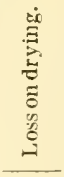 } & \multirow{2}{*}{ 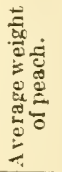 } \\
\hline & & & & 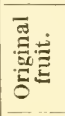 & 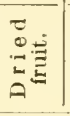 & 㺼 & 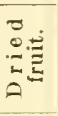 & & & & \\
\hline $23196^{2}$ & $\begin{array}{l}\text { 4h lbs. hydratedlime, } 2 \\
\text { lbs. lead arsenate } \\
\text { (powder). } \\
2 \text { lbs. lead arsenate(pow- } \\
\text { der), } 32 \text { lbs.hydrated } \\
\text { lime, } 16 \text { lbs. silphur. } \\
\text { 16 lbs. sulphur, } 34 \text { lbs. } \\
\text { hydrated lime. }\end{array}$ & 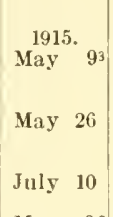 & $\begin{array}{l}\text { Whole 4. } \\
\text { Pulp.... } \\
\text { Shin... }\end{array}$ & $\begin{array}{r}\quad P \\
0.13 \\
.06 \\
.42\end{array}$ & $\begin{array}{r}r t s p e t \\
0.90 \\
.40 \\
2.60\end{array}$ & $\begin{array}{l}\text { millio } \\
0.40 \\
.20 \\
1.20\end{array}$ & $\begin{array}{l}2.7 \\
1.4 \\
7.3\end{array}$ & $\begin{array}{r}\text { Mfg } \\
\text { ped } \\
0.014 \\
.005 \\
.009\end{array}$ & $\begin{array}{l}. p e r \\
\text { ach. } \\
0.042 \\
.016 \\
.026\end{array}$ & $\begin{array}{l}\text { P.ct. } \\
85.3 \\
85.8 \\
83.6\end{array}$ & $\begin{array}{l}\text { Gr. } \\
105.3\end{array}$ \\
\hline $23197^{2}$ & $\begin{array}{l}46 \text { lins. hydrated lime, } \\
4 \text { lbs. lead arsenate } \\
\text { (powder). } \\
32 \text { lbs. sulphur, } 4 \text { lbs. } \\
\text { leadarsenate (powder), } \\
\text { 14 lbs. hydrated lime. } \\
32 \text { lbs. sulphur, 1s lbs. } \\
\text { hydrated lime. }\end{array}$ & $\begin{array}{ll}\text { May } & 9^{3} \\
\text { May } & 26 \\
\text { July } & 10\end{array}$ & $\begin{array}{l}\text { Whole 4. } \\
\text { Pulp.... } \\
\text { Skin... }\end{array}$ & $\begin{array}{l}.18 \\
.08 \\
.61\end{array}$ & $\begin{array}{r}1.30 \\
.60 \\
4.00\end{array}$ & $\begin{array}{r}.40 \\
.10 \\
1.60\end{array}$ & $\begin{array}{r}2.8 \\
.7 \\
10.4\end{array}$ & $\begin{array}{l}.018 \\
.006 \\
.012\end{array}$ & $\begin{array}{l}.040 \\
.005 \\
.032\end{array}$ & $\begin{array}{l}85.7 \\
86.0 \\
84.6\end{array}$ & 100.5 \\
\hline $2319 \& 2$ & $\begin{array}{l}44 \text { lbs. hydrated lime, } \\
6 \text { lbs. lead arsenate } \\
\text { (powder). } \\
44 \text { lbs. sulphur, } 6 \text { lbs. } \\
\text { lead arsenate (powder). } \\
\text { Sulphur alone........... }\end{array}$ & $\begin{array}{ll}\text { May } & 9^{3} \\
\text { May } & 26 \\
\text { July } & 10\end{array}$ & $\begin{array}{l}\text { Whole 4. } \\
\text { Pulp.... } \\
\text { Skin.... }\end{array}$ & $\begin{array}{l}.25 \\
.05 \\
.90\end{array}$ & $\begin{array}{r}1.80 \\
.60 \\
6.10\end{array}$ & $\begin{array}{r}.80 \\
.20 \\
3.00\end{array}$ & $\begin{array}{r}5.7 \\
1.4 \\
20.4\end{array}$ & $\begin{array}{l}.024 \\
.006 \\
.018\end{array}$ & $\begin{array}{l}.076 \\
.015 \\
.061\end{array}$ & $\begin{array}{l}85.9 \\
86.1 \\
85.3\end{array}$ & 45.2 \\
\hline $23199^{2}$ & $\begin{array}{l}\text { 1lb. lead arsenate (pow- } \\
\text { der), } 50 \text { galls. water. } \\
50 \text { galls. self-boiled lime- } \\
\text { sulphur, } 1 \text { lb. lead ar- } \\
\text { senate (powder). } \\
\text { self-boiled lime-sulphur. }\end{array}$ & $\begin{array}{cc}\text { May } & 9^{3} \\
\text { May } & 26 \\
\text { July } & 10\end{array}$ & $\begin{array}{l}\text { Whole 4. } \\
\text { Pulp... } \\
\text { Skin... }\end{array}$ & $\begin{array}{l}.20 \\
.08 \\
.66\end{array}$ & $\begin{array}{r}1.50 \\
.60 \\
+.20\end{array}$ & $\begin{array}{r}.30 \\
.10 \\
1.10\end{array}$ & $\begin{array}{r}2.2 \\
.8 \\
7.0\end{array}$ & $\begin{array}{l}.020 \\
.007 \\
.013\end{array}$ & $\begin{array}{l}.029 \\
.008 \\
.021\end{array}$ & $\begin{array}{l}86.2 \\
86.7 \\
84.2\end{array}$ & $9 \times .0$ \\
\hline $23200^{2}$ & Cheek (unsprayed).... & .......... & $\begin{array}{l}\text { Whole } 4 . \\
\text { Pulp.... } \\
\text { Skin.... }\end{array}$ & $\begin{array}{l}.12 \\
.07 \\
.29\end{array}$ & $\begin{array}{r}.90 \\
.50 \\
2.00\end{array}$ & $\begin{array}{l}.0 \\
.0 \\
.0\end{array}$ & $\begin{array}{l}.0 \\
.0 \\
.0\end{array}$ & $\begin{array}{l}.010 \\
.005 \\
.005\end{array}$ & $\begin{array}{r}0 \\
.0 \\
.0\end{array}$ & $\begin{array}{l}86.7 \\
87.0 \\
85.3\end{array}$ & 83.6 \\
\hline $23201^{2}$ & $\begin{array}{l}78 \text { lbs. terra alha, } 32 \text { lbs. } \\
\text { sulphur. } \\
\text { Do } \ldots \ldots \ldots \ldots \ldots \ldots \\
\text { Do } \ldots \ldots \ldots \ldots \ldots \ldots \ldots\end{array}$ & $\begin{array}{ll}\text { May } & 93 \\
\text { May } & 26 \\
\text { July } & 10\end{array}$ & $\begin{array}{l}\text { Whole } \\
\text { Pulp.... } \\
\text { Skin... }\end{array}$ & $\begin{array}{l}.13 \\
.02 \\
.63\end{array}$ & $\begin{array}{r}1.00 \\
.20 \\
+.00\end{array}$ & $\begin{array}{l}.0 \\
.0 \\
.0\end{array}$ & $\begin{array}{l}.0 \\
.0 \\
.0\end{array}$ & $\begin{array}{l}.012 \\
.001 \\
.011\end{array}$ & $\begin{array}{l}.0 \\
.0 \\
.0\end{array}$ & $\begin{array}{l}86.5 \\
87.0 \\
84.3\end{array}$ & 92.2 \\
\hline $23202^{2}$ & 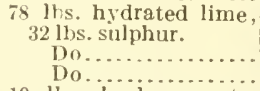 & $\begin{array}{ll}\text { May } & 93 \\
\text { Mas } & 26 \\
\text { July } & 10\end{array}$ & $\begin{array}{l}\text { Whole } \\
\text { Pulp.... } \\
\text { Skin.... }\end{array}$ & $\begin{array}{l}.10 \\
.09 \\
.14\end{array}$ & $\begin{array}{l}.80 \\
.70 \\
.90\end{array}$ & $\begin{array}{l}.0 \\
.0 \\
.0\end{array}$ & $\begin{array}{l}.0 \\
.0 \\
.0\end{array}$ & $\begin{array}{l}.009 \\
.006 \\
.003\end{array}$ & $\begin{array}{l}0 \\
.0 \\
.0\end{array}$ & $\begin{array}{l}86.7 \\
87.1 \\
85.0\end{array}$ & x.. 4 \\
\hline $23203^{2}$ & 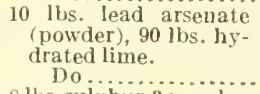 & May 93 & $\begin{array}{l}\text { Whole } 4 . \\
\text { Pulp.... } \\
\text { Skin.... }\end{array}$ & $\begin{array}{l}.13 \\
.08 \\
.35\end{array}$ & $\begin{array}{r}.90 \\
.60 \\
2.10\end{array}$ & $\begin{array}{l}.30 \\
.20 \\
.70\end{array}$ & $\begin{array}{l}2.1 \\
1.4 \\
4.4\end{array}$ & $\begin{array}{l}.013 \\
.007 \\
.006\end{array}$ & $\begin{array}{l}.030 \\
.017 \\
.013\end{array}$ & $\begin{array}{l}8.5 .4 \\
85.8 \\
84.2\end{array}$ & 101.8 \\
\hline $23204^{2}$ & $\begin{array}{l}8 \text { llos. sulphur, } 3 \text { ozs. glue } \\
\text { (used in water to wet } \\
\text { sulphur), 8 lbs. hy- } \\
\text { drated lime, } 1 \text { lh. lead } \\
\text { arsenate (powder), } 50 \\
\text { galls. water. } \\
\text { Do............... } \\
8 \text { lbs. sulphur,3ozs. glue } \\
\text { (used in water to wet } \\
\text { sulphur), } 8 \text { lbs. hy- } \\
\text { drated lime, } 50 \text { galls. } \\
\text { water. }\end{array}$ & $\begin{array}{ll}\text { May } & 26 \\
\text { July } & 10\end{array}$ & $\begin{array}{l}\text { Whole }{ }^{4} . \\
\text { Pulp.... } \\
\text { Skin.... }\end{array}$ & $\begin{array}{l}.10 \\
.04 \\
.34\end{array}$ & $\begin{array}{r}.70 \\
.30 \\
2.10\end{array}$ & $\begin{array}{r}.30 \\
.10 \\
1.00\end{array}$ & $\begin{array}{r}2.0 \\
.7 \\
6.3\end{array}$ & $\begin{array}{l}.009 \\
.003 \\
.006\end{array}$ & $\begin{array}{l}.025 \\
.007 \\
.018\end{array}$ & $\begin{array}{l}85.1 \\
85.4 \\
84.1\end{array}$ & 86.0 \\
\hline
\end{tabular}

1 Where no mention is made of water in the formula the material was applied as dust.

- Delaware variety, hariested Aug. 12-18, Berlin, M d.

- As shucks fell. "Without stones. 
TABLE 5.-Arsenic and lead remaining on sprayed peaches at picking time-Continued.

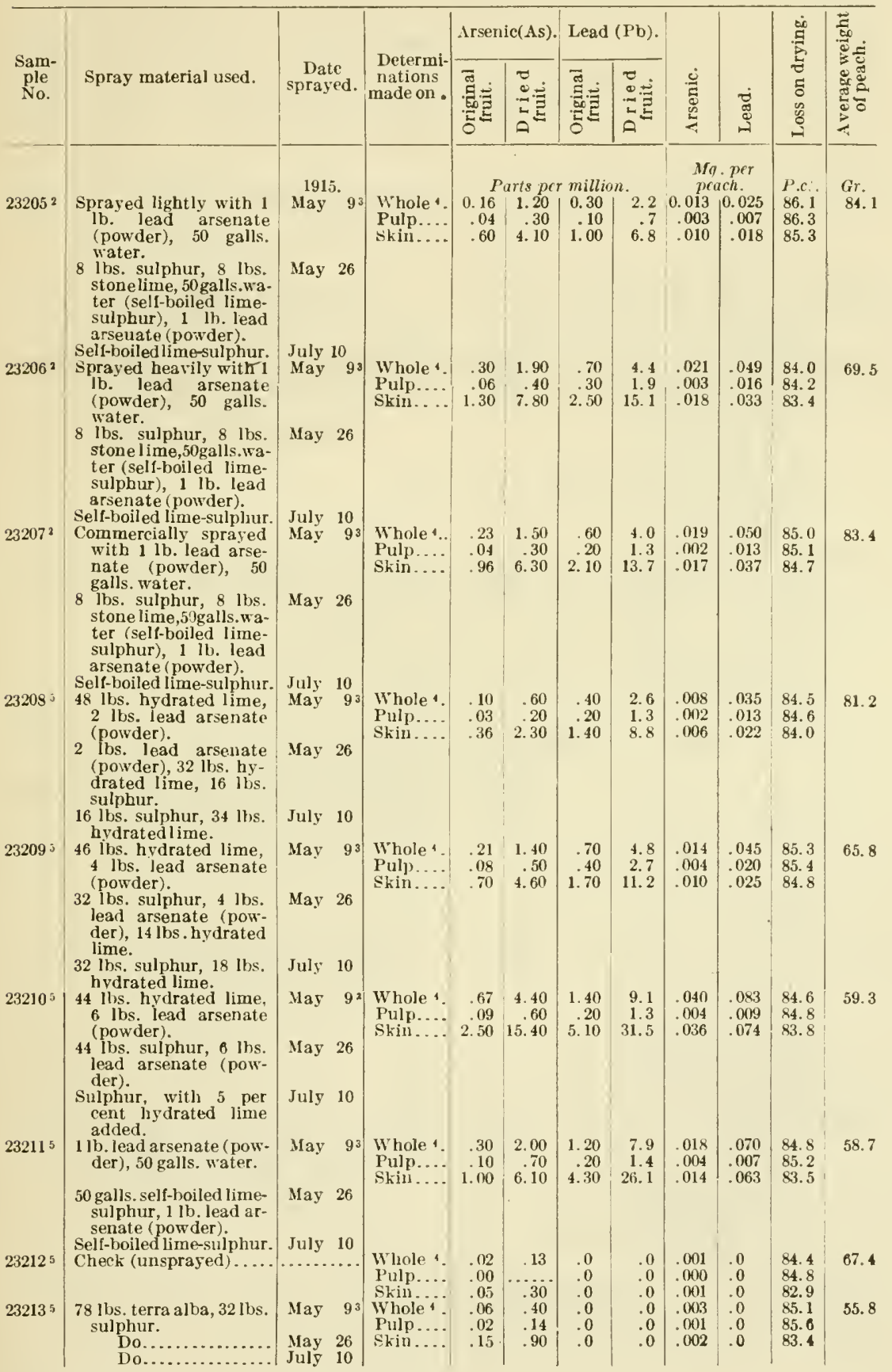

- Delaware variety, harvested Aug. 12-18, Berlin, Md.

- As shucks fell.

6 Delaware variety, harrested Aug. 12-18, Springfield, W. Va. 
TABLE 5.-Arsenic and leud remaining on sprayed penches at picking time-Continued.

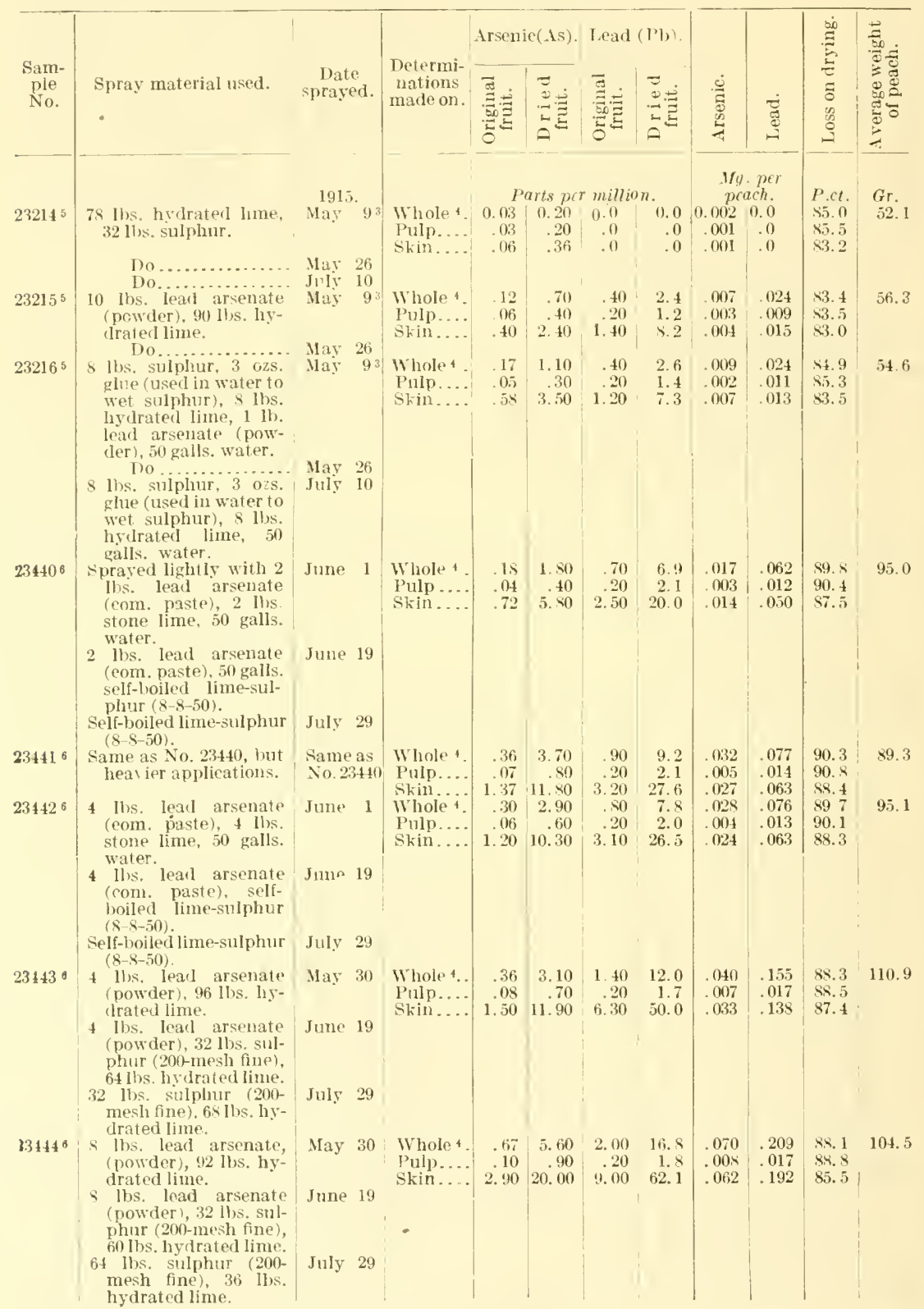

As shueks fell.

4 Without stones.

5 Delaware variety, harrested $\Lambda$ ug. 12-15, springfield, W. Va.

- Elberta variety, harrested Sept. 13, Benton Harbor', Mich. 
TABLE 5.-Arsenic and lead remaining on sprayed peaches at picking time-Continued.

\begin{tabular}{|c|c|c|c|c|c|c|c|c|c|c|c|}
\hline \multirow[b]{2}{*}{$\begin{array}{l}\text { Sam- } \\
\text { ple } \\
\text { No. }\end{array}$} & \multirow[b]{2}{*}{ Spray material used. } & \multirow[b]{2}{*}{$\begin{array}{c}\text { Date } \\
\text { sprayed. }\end{array}$} & \multirow[b]{2}{*}{$\begin{array}{l}\text { Determi- } \\
\text { llations } \\
\text { madeon. }\end{array}$} & \multicolumn{2}{|c|}{ Arsenie(As). } & \multicolumn{2}{|c|}{ Lead (Pb). } & \multirow[b]{2}{*}{ 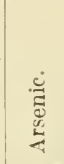 } & \multirow[b]{2}{*}{ تֶ, } & \multirow{2}{*}{ 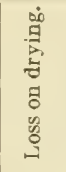 } & \multirow{2}{*}{ 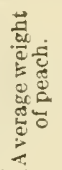 } \\
\hline & & & & 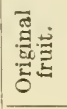 & 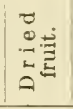 & . & 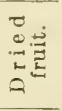 & & & & \\
\hline $23445^{6}$ & $\begin{array}{l}12 \text { Ibs. lead arsenate } \\
\text { (powder), ss lbs. hy- } \\
\text { drated lime. } \\
12 \text { lbs. lead arsenate } \\
\text { (powder), } 88 \text { lbs. sul- } \\
\text { phur (200-mesh fine). } \\
100 \text { lbs. sulphur (200- } \\
\text { mesh fine). }\end{array}$ & $\begin{array}{l}1915 . \\
\text { May } 30 \\
\text { June } 19 \\
\text { July } 29\end{array}$ & $\begin{array}{l}\text { Whole } \\
\text { Pulp.... } \\
\text { Skin... }\end{array}$ & $\begin{array}{r}P \\
0.80 \\
.07 \\
3.50\end{array}$ & $\begin{array}{r}a r t s \text { per } \\
7.10 \\
.60 \\
27.80\end{array}$ & $\begin{array}{r}\text { millio } \\
2.60 \\
.20 \\
11.60\end{array}$ & $\begin{array}{r}n . \\
23.0 \\
1.8 \\
92.1\end{array}$ & $\begin{array}{r}\boldsymbol{M f g} \\
p e d \\
0.0 \div 1 \\
.006 \\
.0 \div 5\end{array}$ & $\begin{array}{l}. \text { per } \\
\text { ach } \\
0.297 \\
.013 \\
.284\end{array}$ & $\begin{array}{l}P . c t . \\
8.7 \\
89.0 \\
87.4\end{array}$ & $\begin{array}{l}G r . \\
114.3\end{array}$ \\
\hline $23446^{\circ}$ & $\begin{array}{l}2 \text { lbs. lead arsenate } \\
\text { (com. paste), } 2 \text { lbs. } \\
\text { stone lime, } 50 \text { gails. } \\
\text { water. } \\
2 \text { lhs. lead arsenate } \\
\text { (eom. paste), self- } \\
\text { boiled line-sulphur } \\
\text { (8-8-50). } \\
\text { Self-boiled lime-sulphur } \\
(8-8-50) \text {. }\end{array}$ & July 29 & $\begin{array}{l}\text { Whole } 4 \\
\text { Pulp.... } \\
\text { Skin... }\end{array}$ & $\begin{array}{r}.42 \\
.10 \\
1.50\end{array}$ & $\begin{array}{r}4.00 \\
1.00 \\
12.50 \\
.\end{array}$ & $\begin{array}{r}1.10 \\
.20 \\
4.10\end{array}$ & $\begin{array}{r}10.4 \\
2.0 \\
34.2\end{array}$ & $\begin{array}{l}.041 \\
.004 \\
.036\end{array}$ & $\begin{array}{l}.115 \\
.016 \\
.099\end{array}$ & $\begin{array}{l}89.4 \\
89.8 \\
86.0\end{array}$ & 104.7 \\
\hline $23447^{\circ}$ & 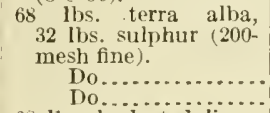 & $\begin{array}{l}\text { May } 30 \\
\text { June } 19 \\
\text { July } 29\end{array}$ & $\begin{array}{l}\text { Whole } 4 . \\
\text { Pulp.... } \\
\text { Skin... }\end{array}$ & $\begin{array}{l}.20 \\
.10 \\
.60\end{array}$ & $\begin{array}{r}1.80 \\
.90 \\
\text { 4. } 90\end{array}$ & $\begin{array}{r}.34 \\
.10 \\
1.20\end{array}$ & $\begin{array}{r}3.0 \\
.9 \\
9.5\end{array}$ & $\begin{array}{l}.020 \\
.005 \\
.012\end{array}$ & $\begin{array}{l}.034 \\
.010 \\
.024\end{array}$ & $\begin{array}{r}88.8 \\
59.1 \\
\times 7.8\end{array}$ & 100.5 \\
\hline $23448^{\circ}$ & $\begin{array}{l}68 \text { lbs. hydrated lime, } \\
32 \text { lbs. sulphur ( } 200- \\
\text { mesh fine). }\end{array}$ & $\begin{array}{ll}\text { May } 30 \\
\text { June } 19 \\
\text { July } 29\end{array}$ & $\begin{array}{l}\text { Whole } 4 . \\
\text { Pulp.... } \\
\text { Skin.... }\end{array}$ & $\begin{array}{r}.24 \\
.07 \\
1.10\end{array}$ & $\begin{array}{r}2.30 \\
.70 \\
8.70\end{array}$ & $\begin{array}{r}.60 \\
.20 \\
2.50\end{array}$ & $\begin{array}{r}5.7 \\
1.9 \\
19.7\end{array}$ & $\begin{array}{l}.02 t i \\
.006 \\
.020\end{array}$ & $\begin{array}{l}.065 \\
.020 \\
.045\end{array}$ & $\begin{array}{r}89.4 \\
89.8 \\
\times 7.3\end{array}$ & 107.5 \\
\hline $23449^{\circ}$ & 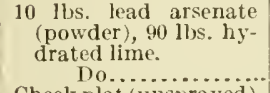 & $\begin{array}{l}\text { May } 30 \\
\text { June } 19\end{array}$ & $\begin{array}{l}\text { Wholet. } \\
\text { Pulp.... } \\
\text { Skin... }\end{array}$ & $\begin{array}{r}.94 \\
.14 \\
4.50\end{array}$ & $\begin{array}{r}8.00 \\
1.20 \\
35.40\end{array}$ & $\begin{array}{r}2.40 \\
.20 \\
12.20\end{array}$ & $\begin{array}{r}20.5 \\
1.7 \\
96.1\end{array}$ & $\begin{array}{l}.115 \\
.014 \\
.101\end{array}$ & $\begin{array}{l}.295 \\
.020 \\
.275\end{array}$ & $\begin{array}{l}8 . .3 \\
8.5 .5 \\
87.3\end{array}$ & 122.8 \\
\hline $23450^{8}$ & Check plat (unsprayed). & .......... & $\begin{array}{l}\text { Whole } 4 . \\
\text { Pulp.... } \\
\text { Skin .... }\end{array}$ & $\begin{array}{l}.23 \\
10 \\
: 77\end{array}$ & $\begin{array}{r}2.00 \\
.90 \\
6.10\end{array}$ & $\begin{array}{r}.40 \\
.14 \\
1.50\end{array}$ & $\begin{array}{r}3.4 \\
1.2 \\
11.9\end{array}$ & $\begin{array}{l}.026 \\
.009 \\
.017\end{array}$ & $\begin{array}{l}.046 \\
.013 \\
.033\end{array}$ & $\begin{array}{l}56.3 \\
88.5 \\
87.4\end{array}$ & 114.2 \\
\hline $25637^{7}$ & Cheek plat (unsprayed). & $\begin{array}{c}\text { 1乡16. } \\
\ldots . . .\end{array}$ & $\begin{array}{l}\text { Whole } 4 . \\
\text { Hulp.... } \\
\text { Skin } . . .\end{array}$ & $\begin{array}{l}.04 \\
.01 \\
.20\end{array}$ & $\begin{array}{r}.30 \\
.10 \\
1.20\end{array}$ & $\begin{array}{r}.40 \\
.30 \\
.90\end{array}$ & $\begin{array}{l}\text { 2. } 7 \\
2.2 \\
5.3\end{array}$ & $\begin{array}{l}.005 \\
.001 \\
.004\end{array}$ & $\begin{array}{l}.052 \\
.031 \\
.021\end{array}$ & $\begin{array}{l}85.1 \\
86.4 \\
83.0\end{array}$ & 129.4 \\
\hline 256387 & $\begin{array}{l}\text { Self-boiled lime-sulphur } \\
(8-8-50), 2 \text { lbs. lead } \\
\text { arsenate. }\end{array}$ & $\begin{array}{l}\text { A bout } \\
\text { May } 13\end{array}$ & $\begin{array}{l}\text { Whole } 1 . \\
\text { Pulp.... } \\
\text { Skin .... }\end{array}$ & $\begin{array}{l}.05 \\
.01 \\
.20\end{array}$ & $\begin{array}{r}.30 \\
.10 \\
1.10\end{array}$ & $\begin{array}{r}.50 \\
.40 \\
.90\end{array}$ & $\begin{array}{l}3.4 \\
2.9 \\
5.2\end{array}$ & $\begin{array}{l}.005 \\
.001 \\
.004\end{array}$ & $\begin{array}{l}.045 \\
.028 \\
.017\end{array}$ & $\begin{array}{l}85.4 \\
86.2 \\
\times 2.6\end{array}$ & 90.9 \\
\hline 256397 & $\begin{array}{l}2 \text { lbs. lead arsenate, } 50 \\
\text { galls. water. } \\
5 \text { lbs. "soluble sulphur } \\
\text { compd."' } 3 \text { lbs. lime, } \\
50 \text { galls. water, } 2 \text { lbs. } \\
\text { lead arsenate. } \\
4 \text { lbs. "soluble sulplur } \\
\text { eompd.," } 4 \text { lbs. lime, } \\
50 \text { galls. water. }\end{array}$ & $\begin{array}{c}3 \text { weeks } \\
\text { later }\end{array}$ & $\begin{array}{l}\text { Whole }{ }^{4} \\
\text { Pulp... } \\
\text { Skin... }\end{array}$ & $\begin{array}{l}.05 \\
.01 \\
.20\end{array}$ & $\begin{array}{r}.30 \\
.10 \\
1.20\end{array}$ & $\begin{array}{r}.50 \\
.30 \\
1.30\end{array}$ & $\begin{array}{l}3.5 \\
2.1 \\
7.7\end{array}$ & $\begin{array}{l}.005 \\
.001 \\
.004\end{array}$ & $\begin{array}{l}.051 \\
.025 \\
.026\end{array}$ & $\begin{array}{r}85.7 \\
\times .9 \\
83.1\end{array}$ & 102.3 \\
\hline $25708^{8}$ & Check plat (unsprayed). & & $\begin{array}{l}\text { Whole } 1 . \\
\text { Pulp.... } \\
\text { Skin ... }\end{array}$ & $\begin{array}{l}.06 \\
.03 \\
.20\end{array}$ & $\begin{array}{r}.40 \\
.20 \\
1.20\end{array}$ & $\begin{array}{l}.40 \\
.30 \\
.90\end{array}$ & $\begin{array}{l}2.7 \\
2.2 \\
5.6\end{array}$ & $\begin{array}{l}.005 \\
.002 \\
.003\end{array}$ & $\begin{array}{l}.034 \\
.021 \\
.013\end{array}$ & $\begin{array}{l}85.3 \\
67.4 \\
83.9\end{array}$ & 85.5 \\
\hline $25709^{8}$ & $\begin{array}{l}1 \text { lb. lead arsenate } \\
\text { (powder), } 2 \text { lbs. stone } \\
\text { lime, } 50 \text { galls. water. } \\
1 \text { lb. lead arsenate } \\
\text { (powder), self-boiled } \\
\text { lime-sulphur ( } \$-8-50) \text {. } \\
\text { Self-boiled lime-sulphur } \\
(8-5-50) \text {. }\end{array}$ & $\begin{array}{ll}\text { May } & 29- \\
\text { May } & 30 \\
\text { June } & 20- \\
\text { June } & 21 \\
\text { Aug. } & 1- \\
\text { Aug. } & 2\end{array}$ & $\begin{array}{l}\text { Whole } 4 \\
\text { Pulp.... } \\
\text { Skin... }\end{array}$ & $\begin{array}{l}.04 \\
.03 \\
.30\end{array}$ & $\begin{array}{r}.70 \\
.30 \\
2.20\end{array}$ & $\begin{array}{l}.40 \\
.30 \\
.90\end{array}$ & $\begin{array}{l}3.7 \\
2.9 \\
6.6\end{array}$ & $\begin{array}{l}.005 \\
.002 \\
.006\end{array}$ & $\begin{array}{l}.042 \\
.025 \\
.017\end{array}$ & $\begin{array}{l}89.1 \\
89.5 \\
86.3\end{array}$ & 105.6 \\
\hline
\end{tabular}

3 As shueks fell.

Without stones.

- Elberta variety, harvested Sept. 13, Bent on Harbor, Micb.

- Elberta variety, harvested Aug. 21, Springfield, W. Va.

- Elberta variety, harvested Sept. 16, Benton Harbor, Mich. 
TABLE 5.-Arsenic and lead remaining on sprayed peaches at picking time--Continued.

\begin{tabular}{|c|c|c|c|c|c|c|c|c|c|c|c|}
\hline \multirow[b]{2}{*}{$\begin{array}{l}\text { Sant- } \\
\text { ple } \\
\text { No. }\end{array}$} & \multirow[b]{2}{*}{ Spray material used. } & \multirow[b]{2}{*}{$\begin{array}{c}\text { Date } \\
\text { sprayed. }\end{array}$} & \multirow[b]{2}{*}{$\begin{array}{c}\text { Determi- } \\
\text { nations } \\
\text { made on. }\end{array}$} & \multicolumn{2}{|c|}{ Arsenic(As). } & \multicolumn{2}{|c|}{ Lead $(\mathrm{Pb})$. } & \multirow[b]{2}{*}{ 总 } & \multirow[b]{2}{*}{$\underset{\leftrightarrows}{\overparen{\Xi}}$} & \multirow{2}{*}{ 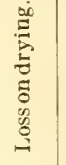 } & \multirow{2}{*}{ 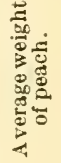 } \\
\hline & & & & 总. & $\stackrel{\Xi}{a}$ & 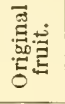 & a. & & & & \\
\hline $27 ! 35^{9}$ & $\begin{array}{l}\text { Ib. lead arsenate } \\
\text { (powder), } 21 \text { lbs. lime, } \\
50 \text { galls. water. } \\
\text { s lis. sulphur, 8 lbs. } \\
\text { hydrated lime, } 3 \text { ozs. } \\
\text { glue, I lb. lead arse- } \\
\text { nate (powder), 50 } \\
\text { galls. water. } \\
\text { s lbs. sulphur, } 8 \text { lbs. } \\
\text { hydrated lime, } 3 \text { ozs. } \\
\text { ghe, } 50 \text { galls. water. }\end{array}$ & $\begin{array}{l}\text { 1917. } \\
\text { Apr. } 4 \\
\text { Apr. } 19\end{array}$ & $\begin{array}{l}\text { Whole 4. } \\
\text { Pulp.... } \\
\text { Skin... }\end{array}$ & $\begin{array}{r}P \\
0.05 \\
.01 \\
.20\end{array}$ & $\begin{array}{l}r t s p e \\
0.30 \\
.10 \\
1.20\end{array}$ & $\begin{array}{l}\text { millio } \\
1.00 \\
.40 \\
4.20\end{array}$ & $\begin{array}{r}n . \\
6.9 \\
3.0 \\
25.8\end{array}$ & $\begin{array}{r}M g . \\
p e \\
0.004 \\
.001 \\
.003\end{array}$ & $\begin{array}{l}\text { per } \\
\text { ch. } \\
0.095 \\
.032 \\
.063\end{array}$ & $\begin{array}{l}\text { P.ct. } \\
85.5 \\
86.6 \\
83.7\end{array}$ & $\begin{array}{l}G r . \\
95.0\end{array}$ \\
\hline $27936^{9}$ & Check (unsprayed) ..... & & $\begin{array}{l}\text { Whole 4. } \\
\text { Pulp.... } \\
\text { Skin ... }\end{array}$ & $\begin{array}{l}.0 \\
.0 \\
.0\end{array}$ & $\begin{array}{l}.0 \\
.0 \\
.0\end{array}$ & $\begin{array}{r}.60 \\
.40 \\
\text { I. } 70\end{array}$ & $\begin{array}{l}4.0 \\
2.8 \\
9.8\end{array}$ & $\begin{array}{l}.0 \\
.0 \\
.0\end{array}$ & $\begin{array}{l}.057 \\
.032 \\
.025\end{array}$ & $\begin{array}{l}85.0 \\
85.7 \\
82.6\end{array}$ & 95.4 \\
\hline $27937^{9}$ & $\begin{array}{l}10 \text { lbs. lead arsenate } \\
\text { (powder), jo lbs. hy- } \\
\text { drated lime. } \\
\text { ure sulphur........... }\end{array}$ & $\begin{array}{l}\text { Apr. } 4 \\
\text { Apr. } 19 \\
\text { June } 7\end{array}$ & $\begin{array}{l}\text { Whole } \\
\text { Pulp... } \\
\text { Skin... }\end{array}$ & $\begin{array}{l}.02 \\
.01 \\
.04\end{array}$ & $\begin{array}{l}10 \\
.10 \\
.20\end{array}$ & $\begin{array}{r}.90 \\
.60 \\
2.40\end{array}$ & $\begin{array}{r}6.3 \\
4.3 \\
14.0\end{array}$ & $\begin{array}{l}.002 \\
.001 \\
.001\end{array}$ & $\begin{array}{l}.086 \\
.045 \\
.038\end{array}$ & $\begin{array}{l}85.6 \\
86.0 \\
82.8\end{array}$ & 96.2 \\
\hline 279389 & $\begin{array}{l}\text { Conunereial preparation } \\
\text { containing } 50 \text { per cent } \\
\text { sulphur and } 50 \text { per } \\
\text { cent lead arsenate. }\end{array}$ & $\begin{array}{l}\text { Apr. } 4 \\
\text { Apr. } 19 \\
\text { June } 7\end{array}$ & $\begin{array}{l}\text { Whole }+ \\
\text { Pulp... } \\
\text { Skin... }\end{array}$ & $\begin{array}{l}07 \\
.0 \\
.40\end{array}$ & $\begin{array}{r}.50 \\
.0 \\
2.30\end{array}$ & $\begin{array}{r}1.20 \\
.80 \\
3.30\end{array}$ & $\begin{array}{r}\text { 8. } 0 \\
\text { 5. } 6 \\
19.2\end{array}$ & $\begin{array}{l}.00 \mathrm{f} \\
.0 \\
.006\end{array}$ & $\begin{array}{l}.110 \\
.062 \\
.048\end{array}$ & $\begin{array}{l}85.0 \\
85.6 \\
82.6\end{array}$ & 91.5 \\
\hline
\end{tabular}

4 Without stones.

- Harvested July 9, Fort Valley, Ga.

TABLE 6.-Arsenic, lead, and copper remaining on sprayed cherries at picking time.

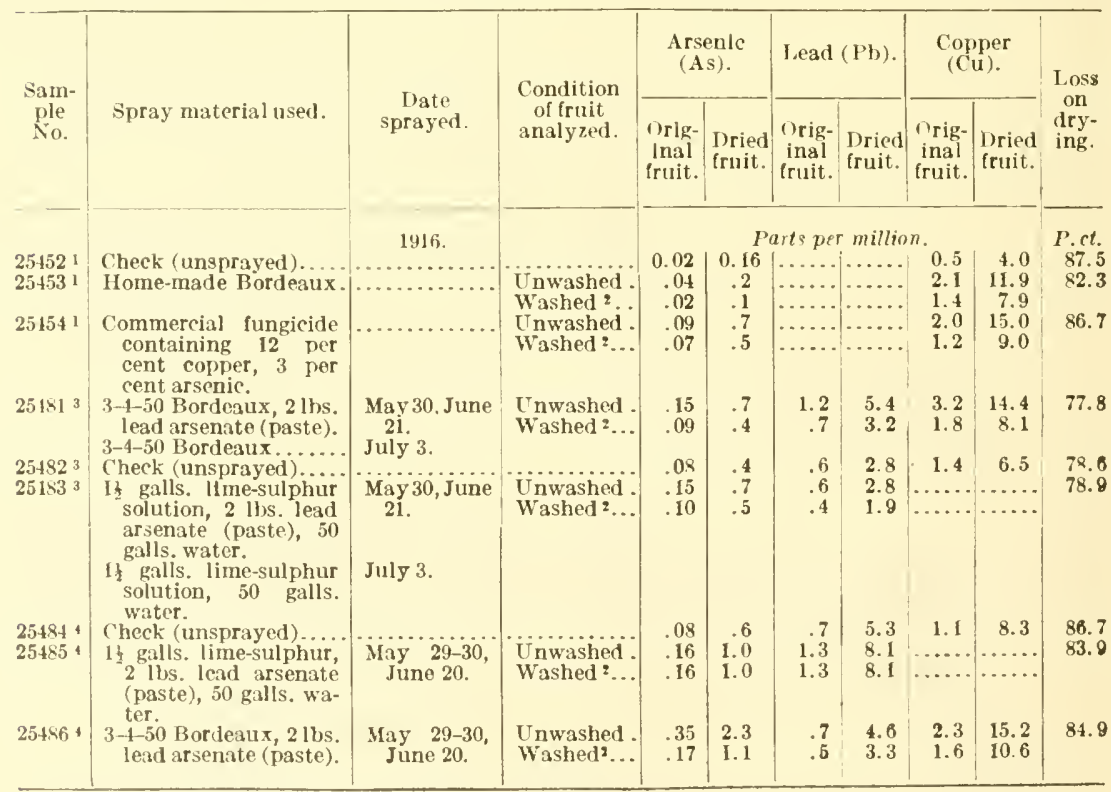

1 Picked July 12,1916, Wenatchee, Wash.

- Washed by holding under running tap water for a few mlnutes.

- Sweet cherries, picked July 20, 1916, Hart, Mich.

t Sour cherries, picked July 20, 1916, Hart, Mich. 
TABLE 7.-Arsenic, lead, and copper remaining on sprayed plums at picking time.

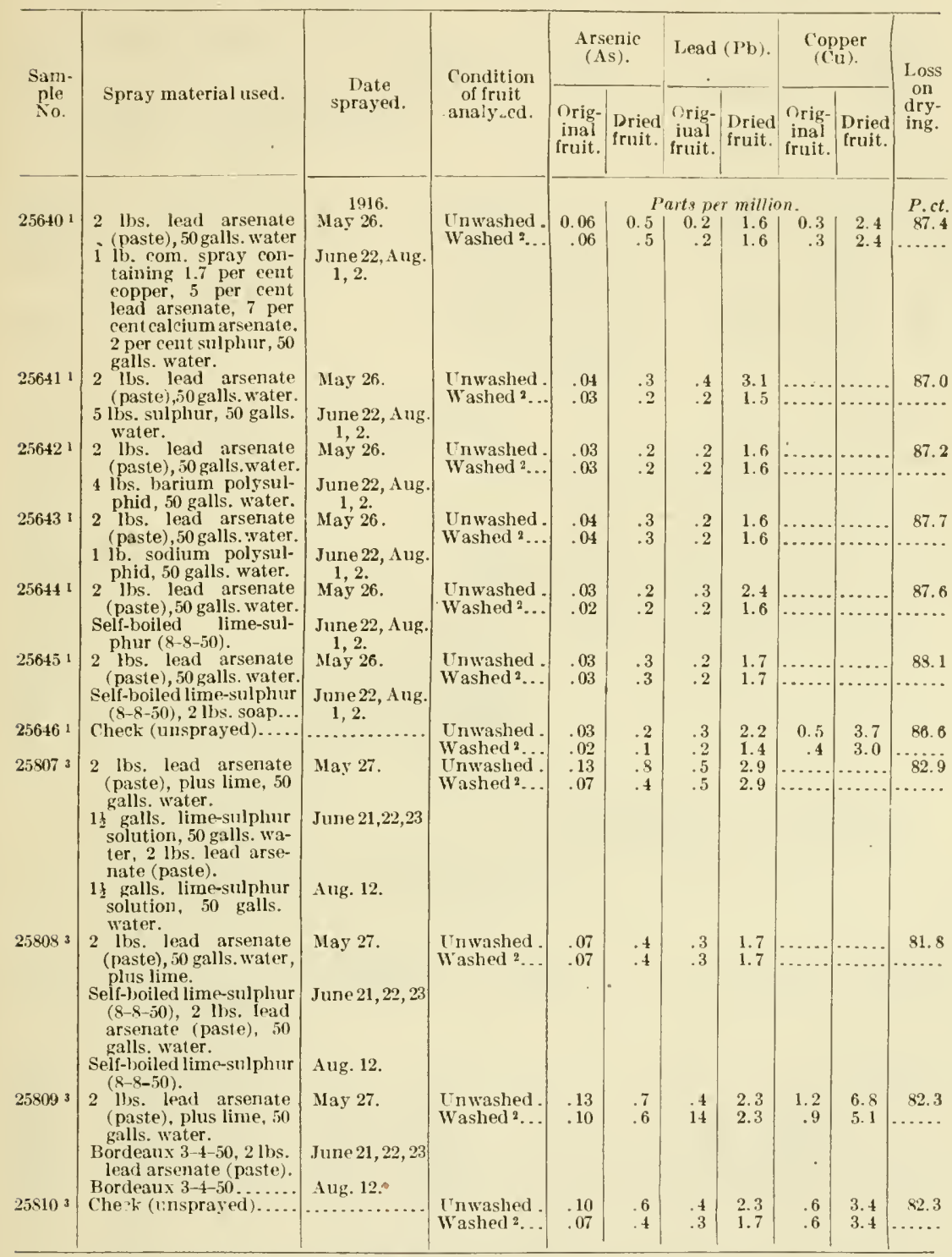

1 Rurbant: pinked last of Angust, Hart, Mich.

2 Washed by holdling under running tap water for a few minutes.

3 Golden Domestira; piched last of September, Hart, Mich. 
TABLE 8.-Irsenic, lead, and copper remining on sprayed tomatoes at picking time.

\begin{tabular}{|c|c|c|c|c|c|c|c|c|c|c|}
\hline \multirow{2}{*}{$\begin{array}{l}\text { Sam- } \\
\text { ple } \\
\text { No. }\end{array}$} & \multirow{2}{*}{$\begin{array}{l}\text { Spray material } \\
\text { ised. }\end{array}$} & \multirow{2}{*}{$\begin{array}{l}\text { Date } \\
\text { sprayed. }\end{array}$} & \multirow{2}{*}{$\begin{array}{c}\text { Determina- } \\
\text { tions } \\
\text { made on. }\end{array}$} & \multicolumn{2}{|c|}{$\begin{array}{l}\text { Arsenic } \\
\text { (As). }\end{array}$} & \multicolumn{2}{|c|}{ 1.ead $(\mathrm{Pb})$. } & \multicolumn{2}{|c|}{$\begin{array}{l}\text { Copper } \\
\text { (('u). }\end{array}$} & \multirow{2}{*}{$\begin{array}{l}\text { Loss } \\
\text { on } \\
\text { dry- } \\
\text { ing. }\end{array}$} \\
\hline & & & & $\begin{array}{l}\text { Origi- } \\
\text { nal } \\
\text { fruit. }\end{array}$ & $\begin{array}{l}\text { Dried } \\
\text { fruit. }\end{array}$ & $\begin{array}{l}\text { Origi } \\
\text { nal } \\
\text { fruit. }\end{array}$ & $\begin{array}{l}\text { Dried } \\
\text { fruit. }\end{array}$ & $\begin{array}{l}\text { Origi- } \\
\text { nal } \\
\text { fruit. }\end{array}$ & $\begin{array}{l}\text { I) ried } \\
\text { Iruit. }\end{array}$ & \\
\hline 233041 & Check (unsprayed). & $\begin{array}{l}1915 . \\
\cdots \cdots\end{array}$ & Whole fruil. & \multicolumn{6}{|c|}{ Parts per million. } & $\begin{array}{l}P . c t \text {. } \\
94.0\end{array}$ \\
\hline $23305^{1}$ & $\begin{array}{l}8-9-50 \text { Bordeaux mix- } \\
\text { ture. }\end{array}$ & $\begin{array}{l}\text { July \&, } 19, \\
21,31, \text { tug. }\end{array}$ & $\begin{array}{l}\text { Pulp....... } \\
\text { Whole iruit. } \\
\text { Pulp....... }\end{array}$ & & & & & $\begin{array}{l}1.2 \\
5.7 \\
2.2\end{array}$ & $\begin{array}{l}20.0 \\
91.9 \\
35.5\end{array}$ & $\begin{array}{l}94.0 \\
93.8 \\
93.8\end{array}$ \\
\hline $23306 \mathrm{I}$ & 5-6-50 Bordeaux...... & $\begin{array}{l}\text { Sept, } 11 . \\
\text { July, } 19, \\
20,31, \text { A1 } \\
5,10.18, \\
\text { Sept. } 4,11 \text {. }\end{array}$ & $\begin{array}{l}\text { Whole fruit. } \\
\text { Pulp....... }\end{array}$ & & & & & $\begin{array}{l}5.7 \\
1.6\end{array}$ & $\begin{array}{l}91.9 \\
25.8\end{array}$ & $\begin{array}{l}93.8 \\
93.8\end{array}$ \\
\hline $25 t i 64^{2}$ & Check (unsprayed).. & $\begin{array}{c}1916 . \\
\ldots . \ldots . . .\end{array}$ & Whole fruit. & .0 .02 & 0.4 & 0.9 & 16.1 & .6 & 10.7 & 94.4 \\
\hline $25665^{2}$ & $\begin{array}{l}5-5-50 \text { Bordeanx, } 1 \frac{1}{2} \text { lbs } \\
\text { lead arsenate (pow- } \\
\text { der). }\end{array}$ & $\begin{array}{l}\text { July } 13 \text {. A ug. } \\
7,25, \text { sept. }\end{array}$ & $\begin{array}{l}\text { Pulp....... } \\
\text { Whole fruit. } \\
\text { Pulp....... }\end{array}$ & $\begin{array}{l}.02 \\
.3 \\
.05 \\
-.05\end{array}$ & $\begin{array}{r}.4 \\
5.2 \\
.9\end{array}$ & $\begin{array}{r}.6 \\
1.7 \\
1.2\end{array}$ & $\begin{array}{l}10.7 \\
29.5 \\
21.1\end{array}$ & $\begin{array}{r}.5 \\
1.0 \\
.6\end{array}$ & $\begin{array}{r}8.9 \\
17.5 \\
10.5\end{array}$ & $\begin{array}{l}94.4 \\
94.3 \\
94.3\end{array}$ \\
\hline 2552.53 & Check (unsprayed).... & & $\begin{array}{l}\text { Whole fruit. } \\
\text { Pulp }\end{array}$ & .07 & 1.4 & .3 & 6. 0 & .7 & 14.0 & 95. 0 \\
\hline $25826^{3}$ & $\begin{array}{l}5-5-50 \text { Bordeanx, } 12 \mathrm{lbs} \text {. } \\
\text { lead arsenate (pow- } \\
\text { der). } \\
5-5-50 \text { Bordeaux. . . . }\end{array}$ & $\begin{array}{l}\text { July } 13, \text { Aug. } \\
7,25 \text {, Sept. } \\
\text { s. } \\
\text { Sept. 1s. }\end{array}$ & $\begin{array}{l}\text { Whole fruit. } \\
\text { Pulp....... }\end{array}$ & $\begin{array}{l}.07 \\
.07\end{array}$ & $\begin{array}{r}1.1 \\
.3\end{array}$ & $\begin{array}{l}.5 \\
.5\end{array}$ & $\begin{array}{l}7.0 \\
7.6 \\
3.3\end{array}$ & $\begin{array}{r}4.0 \\
.9\end{array}$ & $\begin{array}{l}60.0 \\
13.6\end{array}$ & $\begin{array}{l}93.4 \\
93.4\end{array}$ \\
\hline 257064 & $4-4-50$ Bordeaux ....... & & $\begin{array}{l}\text { Whole fruit. } \\
\text { Pulp....... }\end{array}$ & & & & & $\begin{array}{l}.9 \\
.5\end{array}$ & $\begin{array}{r}17.0 \\
9.4\end{array}$ & $\begin{array}{l}94.7 \\
94.7\end{array}$ \\
\hline 257074 & Cherk (unsprayed). . & & Whole fruit. & & & & & $\begin{array}{l}.0 \\
.6\end{array}$ & $\begin{array}{r}10.5 \\
8.8\end{array}$ & $\begin{array}{l}94.3 \\
94.3\end{array}$ \\
\hline $25710^{4}$ & Cheek (unsprayed).. & & Whole fruit. & & & & & .7 & 13.2 & 94.7 \\
\hline $25711^{4}$ & 4-4-50 Bordeaux. & & $\begin{array}{l}\text { Whyolefruit. } \\
\text { Pulp....... }\end{array}$ & & & & ( & $\begin{array}{l}.7 \\
.8 \\
.7\end{array}$ & $\begin{array}{l}13.2 \\
14.3 \\
12.5\end{array}$ & $\begin{array}{l}94.7 \\
94.4 \\
94.4\end{array}$ \\
\hline
\end{tabular}

1 Fruit pieked Sept. 15, 1915, Camden, N. J.

2 Fruit picked Sept. 14, 1916 Arlington, $\mathrm{V}$ a.

${ }^{3}$ Fruit pieked wet, 2,1916, Arlington, Va.

4 Fruit pickerl Sept. 15, 1916, Salem, X. J.; sănples represent commercial fruit ready for market.

TABLE 9.-Copper remaining on sprayed celery at gathering time. ${ }^{1}$

\begin{tabular}{|c|c|c|c|c|c|c|}
\hline \multirow{2}{*}{$\begin{array}{l}\text { Sam- } \\
\text { ple } \\
\text { No. }\end{array}$} & \multirow{2}{*}{ Spray material used. } & \multirow{2}{*}{$\begin{array}{l}\text { Date } \\
\text { sprayed. }\end{array}$} & \multirow{2}{*}{$\begin{array}{l}\text { Determinations } \\
\text { made on. }\end{array}$} & \multicolumn{2}{|c|}{ Copper (Cu). } & \multirow{2}{*}{$\begin{array}{l}\text { Loss on } \\
\text { drying. }\end{array}$} \\
\hline & & & & $\begin{array}{l}\text { Original } \\
\text { celery. }\end{array}$ & $\begin{array}{l}\text { Dried } \\
\text { celery. }\end{array}$ & \\
\hline 235852 & (Ches nlat (unsproved) & 1915. & Wnwoghed (abeat) & Parts por & million. & Percent. \\
\hline $23586=$ & $\begin{array}{l}\text { Orersprayed with } 5-5-50 \\
\text { Bordeain mixture, } 2 \text { lbs. } \\
\text { resin fish-oil soap. }\end{array}$ & $\begin{array}{l}\text { Aig. } 14,24 \\
\text { Sept. } 2,14\end{array}$ & $\begin{array}{l}\text { Unwashed leares } 3 . \\
\text { Unwashed stalks }{ }^{3} . . \\
\text { Washed leares } 4 . . . \\
\text { W ashed stalks } 4\end{array}$ & $\begin{array}{r}25.5 .1 \\
16.6 \\
65.7 \\
5.2\end{array}$ & $\begin{array}{r}2,150.5 \\
207.5 \\
547.5 \\
102.5\end{array}$ & $\begin{array}{l}90.0 \\
\$ 8.0 \\
92.0 \\
88.0 \\
92.0\end{array}$ \\
\hline 235872 & $\begin{array}{l}\text { 5-5-50 Bordeaux mixture, } \\
2 \text { lbs. resin fish-oil soap. }\end{array}$ & $\begin{array}{l}\text { Aug. 14, } 24 \\
\text { Sept. 2, } 14 .\end{array}$ & $\begin{array}{l}\text { Unwashed leaves } 3 . . \\
\text { Tnwashed stalks } 3 . . \\
\text { Washed leaves } 4 . . . \\
\text { Washed stalks } 4 . . .\end{array}$ & $\begin{array}{r}213.0 \\
3.6 \\
\$ 5.5 \\
2.9\end{array}$ & $\begin{array}{r}1,775.0 \\
45.0 \\
712.5 \\
36.3\end{array}$ & $\begin{array}{l}92.0 \\
88.0 \\
92.0 \\
85.0 \\
92.0\end{array}$ \\
\hline $2 \times 7 \times 35$ & $\begin{array}{l}\text { Commercially sprayed with } \\
5-5-50 \text { Bordeaux plus soap. }\end{array}$ & $\begin{array}{l}1917 . \\
\text { Sept. 11, } 22 \text {, } \\
\text { Oet. 1. }\end{array}$ & $\begin{array}{l}\text { Unwashed leaves... } \\
\text { Inwashed stalks... } \\
\text { Washed leaves }{ }^{6} . . . .\end{array}$ & $\begin{array}{r}4.7 \\
.9 \\
2.9\end{array}$ & $\begin{array}{l}33.6 \\
11.5 \\
20.7\end{array}$ & $\begin{array}{l}86.0 \\
92.2 \\
\ldots . .\end{array}$ \\
\hline $2 \triangle 7 \wedge 4^{5}$ & $\begin{array}{l}\text { ()yersprayed with } 5-5-50 \\
\text { Bordeaux plus soap. }\end{array}$ & $\begin{array}{l}\text { Sept. 11, 22, } \\
\text { Oet. 1. }\end{array}$ & $\begin{array}{l}\text { Washed stalks } 6 . . . \\
\text { Tnwashed leaves... } \\
\text { Unwashed stalks.... } \\
\text { Washed leaves } 6 \text {.... } \\
\text { Washed stalks } \text { W }^{6} . . .\end{array}$ & $\begin{array}{r}1.9 \\
1.6 \\
2.6 \\
.7\end{array}$ & $\begin{array}{r}11.5 \\
91.4 \\
20.0 \\
15.0 \\
\times .7\end{array}$ & $\begin{array}{l}86.0 \\
92.0 \\
\cdots \cdots \\
\cdots \cdots\end{array}$ \\
\hline
\end{tabular}

1 The samples spraved in 1915 were coated with eopper sprav when re eived and represent extremely heavy applications; the 1917 samples represent celery as it usually appears on the market.

2 Harvested Oet. 29, 1915, North Liberty, Ind.

These sprayed samples were hearily coated with the spray material when reeeived.

4 Washıng done by holding sample under faueet water for few minutes.

5 Harvested about Nov. 1, 1917, North Liberty, Ind.

6 Washed by soaking celery in water for a short time and then rubbing with small brush. 
TABLE 10.-Copper remaining on sprayed cucumbers ut picking time.

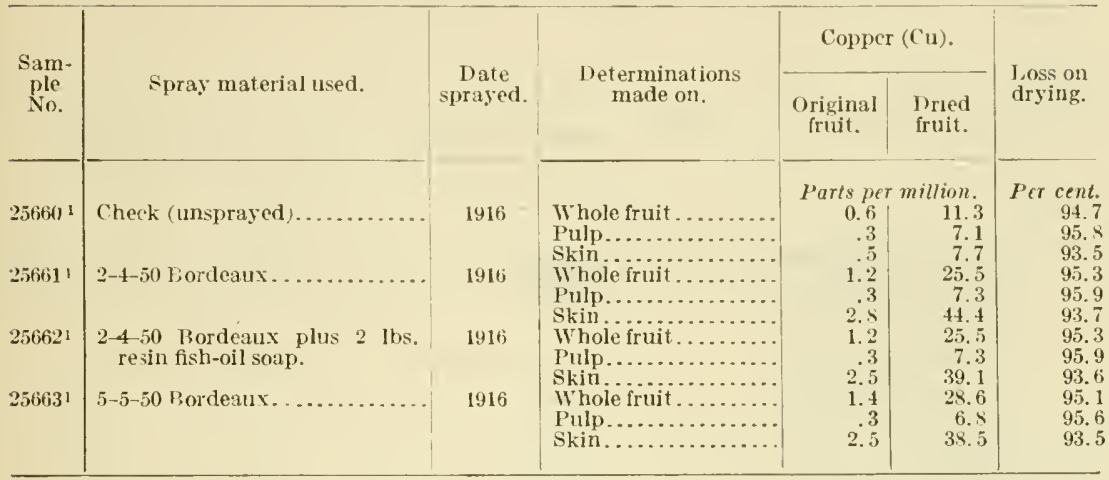

: Cueumbers picked Sept. 9, 1916, Plymouth, Ind.

TABLE 11.-Arsenic, lead, and copper remaining on sprayed cranberries at picking time.

\begin{tabular}{|c|c|c|c|c|c|c|c|c|c|c|}
\hline \multirow{2}{*}{$\begin{array}{l}\text { Sam- } \\
\text { ple } \\
\text { No. }\end{array}$} & \multirow{2}{*}{ Spray material used. } & \multirow{2}{*}{$\begin{array}{c}\text { Date } \\
\text { sprayed. }\end{array}$} & \multirow{2}{*}{$\begin{array}{l}\text { Condition } \\
\text { of fruit } \\
\text { analyzed. }\end{array}$} & \multicolumn{2}{|c|}{$\begin{array}{c}\text { Arsenic } \\
\text { (As). }\end{array}$} & \multicolumn{2}{|c|}{ Lead (Pb). } & \multicolumn{2}{|c|}{$\begin{array}{l}\text { Copper } \\
\text { (Cu). }\end{array}$} & \multirow{2}{*}{$\begin{array}{l}\text { Loss } \\
\text { on } \\
\text { dry- } \\
\text { ing. }\end{array}$} \\
\hline & & & & $\begin{array}{l}\text { Orig- } \\
\text { inal } \\
\text { fruit. }\end{array}$ & $\begin{array}{l}\text { Dried } \\
\text { fruit. }\end{array}$ & $\begin{array}{c}\text { Orig- } \\
\text { inal } \\
\text { fruit. }\end{array}$ & $\begin{array}{l}\text { Dried } \\
\text { fruit. }\end{array}$ & $\begin{array}{l}\text { Orig- } \\
\text { inal } \\
\text { fruit. }\end{array}$ & $\begin{array}{l}\text { Dried } \\
\text { fruit. }\end{array}$ & \\
\hline $23453^{1}$ & $\begin{array}{l}\text { Sprayed lightly with } \\
4-50 \text { Bordeaux, } 2 \\
\text { lbs. resin fish-oil } \\
\text { soap.2 }\end{array}$ & $\begin{array}{l}1915 . \\
\text { June } 24, \text { July } \\
26, \text { Aug. } 11, \\
28 .\end{array}$ & $\begin{array}{l}\text { Unwashed. } \\
\text { Washed }{ }^{3} \text {... }\end{array}$ & & $\mathrm{Pa}$ & rts per & million & $\begin{array}{l}7.4 \\
7.1\end{array}$ & $\begin{array}{l}62.7 \\
60.2\end{array}$ & $\begin{array}{l}\text { P.ct. } \\
88.2 \\
88.2\end{array}$ \\
\hline $2345+1$ & $\begin{array}{l}\text { Sprayed medium with } \\
\text { 4-50 Bordeal1x, } 2 \\
\text { lbs.resin fish-oil soap } \\
\text { (normal spray for re- } \\
\text { gion). }{ }^{2}\end{array}$ & .....do. & $\begin{array}{l}\text { Unwashed. } \\
\text { Washed }{ }^{3} \ldots\end{array}$ & & & & & $\begin{array}{l}3.9 \\
2.3\end{array}$ & $\begin{array}{l}33.9 \\
20.0\end{array}$ & $\begin{array}{l}88.5 \\
88.5\end{array}$ \\
\hline $23455^{1}$ & $\begin{array}{l}\text { Sprayed heavily with } \\
4-40 \text { Bordeaux, } 2 \\
\text { lbs. resin fish-oil } \\
\text { soap. }\end{array}$ & ....do.. & $\begin{array}{l}\text { Unwashed } \\
\text { Washed }{ }^{3} \ldots\end{array}$ & & & & & $\begin{array}{l}7.6 \\
4.8\end{array}$ & $\begin{array}{l}66.1 \\
41.7\end{array}$ & $\begin{array}{l}88.5 \\
88.5\end{array}$ \\
\hline 234561 & $\begin{array}{l}\text { Oversprayed with } 4 \text { - } \\
50 \text { Bordeaux, } 2 \text { lbs. } \\
\text { resin fish-oil soap. } 2\end{array}$ & $\begin{array}{l}\text { June 10, July } \\
10,31 \text {, Aug. } \\
16 .\end{array}$ & $\begin{array}{l}\text { Unwashed. } \\
\text { Washed }{ }^{3} . .\end{array}$ & & & & & $\begin{array}{l}33.3 \\
16.2\end{array}$ & $\begin{array}{l}268.5 \\
130.6\end{array}$ & $\begin{array}{l}87.6 \\
87.6\end{array}$ \\
\hline $23684+$ & $\begin{array}{l}\text { Sprayed heavily with } \\
+4-50 \text { Bordeaux, } \\
\text { lbs. resin fish-oil } \\
\text { soap. } 5\end{array}$ & $\begin{array}{r}\text { June 19, July } \\
27, \text { Aug. } 12 .\end{array}$ & $\begin{array}{l}\text { Unwashed . } \\
\text { Washed }{ }^{3} . .\end{array}$ & & & & & $\begin{array}{l}2.0 \\
1.7\end{array}$ & $\begin{array}{l}15.0 \\
12.8\end{array}$ & $\begin{array}{l}86.7 \\
86.7\end{array}$ \\
\hline $23685^{4}$ & $\begin{array}{l}\text { Sprayed medium with } \\
4-4-50 \text { Bordeaux, } 2 \\
\text { lbs. resin fish-oil soap } \\
\text { (normal spray for re- } \\
\text { gion). } 5\end{array}$ & $\ldots .$. do....... & $\begin{array}{l}\text { Unwashed . } \\
\text { Washed }{ }^{3} . .\end{array}$ & & & & & $\begin{array}{l}2.0 \\
1.5\end{array}$ & $\begin{array}{l}14.4 \\
12.9\end{array}$ & $\begin{array}{l}86.1 \\
86.1\end{array}$ \\
\hline $236 \$ 64$ & $\begin{array}{l}\text { Sprayed lightly with } \\
4 .-50 \text { Bordeaux, } 2 \\
\text { lbs. resin fish-oil } \\
\text { soap. } 5\end{array}$ & .... do.. & $\begin{array}{l}\text { Unwashed } \\
\text { Washed }{ }^{3} . .\end{array}$ & & & & & $\begin{array}{l}2.6 \\
2.4\end{array}$ & $\begin{array}{l}17.9 \\
16.5\end{array}$ & $\begin{array}{l}85.5 \\
85.5\end{array}$ \\
\hline $23687+$ & Check (unsprayed) ${ }^{5} \ldots$ & & & & & & & .9 & 7.1 & 87.4 \\
\hline 257271 & $\begin{array}{l}\text { Commercially sprayed } \\
\text { with } 3-3-50 \text { Bordeaux, } \\
2 \text { lbs. resin fish-oil } \\
\text { soap. } 6\end{array}$ & $\begin{array}{l}1916 . \\
\text { June } 26, \text { July } \\
27, \text { Aug. } 5, \\
25 .\end{array}$ & $\begin{array}{l}\text { Unwashed . } \\
\text { Washed }^{7} . .\end{array}$ & & & & & $\begin{array}{l}\text { 7. } 2 \\
3.0\end{array}$ & $\begin{array}{l}62.1 \\
25.9\end{array}$ & $\begin{array}{l}88.4 \\
88.4\end{array}$ \\
\hline
\end{tabular}

1 Early Black.

Harvested Sept. 18, 1915, Brown Mills, N. J.

- Washed by holding the berries in running tap water.

1 Howe.

3 Harvested Oct. 16, 1915, Brown Mills, N. J.

- Harvested Sept. 18, 1916, Brown Mills, N. J.

Washed by soaking berries in water for a short time, pouring of the water, adding more water, and ropeating operation three times. 
TABLE 11.-Arsenic, lead, and copper remaining on sprayed cranberries at picking timeContinued.

\begin{tabular}{|c|c|c|c|c|c|c|c|c|c|c|}
\hline \multirow{2}{*}{$\begin{array}{l}\text { Sam- } \\
\text { ple } \\
\text { No. }\end{array}$} & \multirow{2}{*}{ Spray material used. } & \multirow{2}{*}{$\begin{array}{l}\text { 1)ate } \\
\text { sprayed. }\end{array}$} & \multirow{2}{*}{$\begin{array}{l}\text { Condition } \\
\text { of fruit } \\
\text { analyzed. }\end{array}$} & \multicolumn{2}{|c|}{$\begin{array}{l}\text { Arsenie } \\
\text { (As). }\end{array}$} & \multicolumn{2}{|c|}{ Lead $(\mathrm{Pb})$. } & \multicolumn{2}{|c|}{$\begin{array}{l}\text { Copper } \\
\text { (Cu). }\end{array}$} & \multirow{2}{*}{$\begin{array}{l}\text { I.oss } \\
\text { on } \\
\text { dry- } \\
\text { ing. }\end{array}$} \\
\hline & & & & $\begin{array}{l}\text { Orig- } \\
\text { inal } \\
\text { fruit. }\end{array}$ & $\begin{array}{l}\text { I) ried } \\
\text { fruit. }\end{array}$ & $\begin{array}{l}\text { ()rig- } \\
\text { inal } \\
\text { fruit. }\end{array}$ & $\begin{array}{l}\text { Dried } \\
\text { fruit. }\end{array}$ & $\begin{array}{l}\text { ()rig- } \\
\text { inal } \\
\text { fruit. }\end{array}$ & $\begin{array}{l}\text { Dried } \\
\text { fruit. }\end{array}$ & \\
\hline & & 1916. & & & & & & & & \\
\hline 26166 & $\begin{array}{l}\text { Sprayed lightly with } \\
4-40 \text { Bordeaux, } 2 \\
\text { lhs.resin fish-oil soap, } \\
2 \text { lbs. lead arsenate } \\
\text { (powder). }{ }^{8}\end{array}$ & Aug. 1, 24 . & $\begin{array}{l}\text { Unwashed } \\
\text { Washed } 7 \text {... }\end{array}$ & $\begin{array}{r}1.2 \\
.8\end{array}$ & $\begin{array}{l}8.7 \\
5.8\end{array}$ & & $\begin{array}{l}34.8 \\
18.1\end{array}$ & $\begin{array}{l}5.5 \\
2.3\end{array}$ & $\begin{array}{l}39.8 \\
16.7\end{array}$ & $\begin{array}{l}86.2 \\
86.2\end{array}$ \\
\hline 26167 & $\begin{array}{l}\text { Sprayed normally with } \\
4-40 \text { Bordeaux, } 2 \\
\text { ibs. resin fish-oilsoap, } \\
2 \text { bs. lead arsenate } \\
\text { (pow der). }{ }^{8}\end{array}$ & ....do... & $\begin{array}{l}\text { Unwashed. } \\
\text { Washed }{ }^{3} . .\end{array}$ & $\begin{array}{l}1.3 \\
1.0\end{array}$ & $\begin{array}{l}9.4 \\
7.2\end{array}$ & $\begin{array}{l}5.7 \\
2.5\end{array}$ & $\begin{array}{l}41.3 \\
18.1\end{array}$ & $\begin{array}{l}6.7 \\
3.1\end{array}$ & $\begin{array}{l}48.6 \\
22.5\end{array}$ & $\begin{array}{l}86.2 \\
86.2\end{array}$ \\
\hline $2616 s$ & $\begin{array}{l}\text { Sprayed heavily with } \\
4-1-50 \text { Bordeaux, } 2 \\
\text { lbs. resin fish-oilsoap, } \\
2 \text { bs. lead arsenate } \\
\text { (powder).8 }\end{array}$ & ....do..... & $\begin{array}{l}\text { Unwashed . } \\
\text { Washed ? ... }\end{array}$ & $\begin{array}{l}1.7 \\
1.0\end{array}$ & $\begin{array}{r}12.8 \\
7.5\end{array}$ & $\begin{array}{l}7.4 \\
3.8\end{array}$ & $\begin{array}{l}55.6 \\
28.6\end{array}$ & $\begin{array}{r}10.0 \\
4.6\end{array}$ & $\begin{array}{l}75.2 \\
34.6\end{array}$ & $\begin{array}{l}86.7 \\
86.7\end{array}$ \\
\hline 26169 & $\begin{array}{l}\text { Oversprayed with } 41 \text { - } \\
50 \text { Bordeaux, } 2 \text { lbs. } \\
\text { arsenate (powder), } 2 \\
\text { lbs resin fish-oil soap. }\end{array}$ & Aug. 2, 24 . & $\begin{array}{l}\text { Unwashed . } \\
\text { Washed ?... }\end{array}$ & $\begin{array}{l}2.5 \\
1.0\end{array}$ & $\begin{aligned} & 19.1 \\
& 7.6\end{aligned}$ & $\begin{array}{l}9.2 \\
4.4\end{array}$ & $\begin{array}{l}70.2 \\
33.6\end{array}$ & $\begin{array}{r}11.4 \\
3.7\end{array}$ & $\begin{array}{l}87.0 \\
28.2\end{array}$ & $\begin{array}{l}89.9 \\
86.6\end{array}$ \\
\hline 26170 & Check (unsprayed) ${ }^{8} \ldots$ & & Unwashed & .1 & .7 & .6 & 4.4 & 1.0 & 7.4 & 86.5 \\
\hline 27337 I & $\begin{array}{l}\text { 4-5-50 Bordeaux, } 2 \text { lhs. } \\
\text { resin fish-oil soap. } 9\end{array}$ & $\begin{array}{l}\text { June } 24, \text { Aug. } \\
3 .\end{array}$ & $\begin{array}{l}\text { Unwashed } \\
\text { Washed } 7 . .\end{array}$ & .1 & .7 & .6 & 4.4 & $\begin{array}{l}1.0 \\
2.2 \\
1.0\end{array}$ & $\begin{array}{r}17.4 \\
17.2 \\
7.8\end{array}$ & $\begin{array}{l}86.5 \\
87.2\end{array}$ \\
\hline $2733 \times 1 c$ & $\begin{array}{l}10 \text { Ibs. lead arsenate } \\
\begin{array}{l}\text { (paste), } \\
\text { water. }{ }^{11}\end{array}\end{array}$ & Jưly 22 & $\begin{array}{l}\text { Wnwashed. } \\
\text { Washed ? }\end{array}$ & .14 & $\begin{array}{l}1.1 \\
1.1\end{array}$ & $\begin{array}{r}1.5 \\
.9\end{array}$ & $\begin{array}{r}11.6 \\
7.0\end{array}$ & & & $\begin{array}{l}87.1 \\
\cdots \cdots\end{array}$ \\
\hline $27339^{10}$ & $\begin{array}{l}10 \text { lbs. lead arsenate } \\
\text { (paste), 21bs. laundry } \\
\text { soap, 50 galls. Water.i1 }\end{array}$ & July $22,24$. & $\begin{array}{l}\text { Unwashed . } \\
\text { Washed } 7 . . .\end{array}$ & $\begin{array}{l}.16 \\
.16\end{array}$ & $\begin{array}{l}1.2 \\
1.2\end{array}$ & $\begin{array}{l}1.1 \\
1.1\end{array}$ & $\begin{array}{l}8.1 \\
8.1\end{array}$ & & & $\begin{array}{r}86.5 \\
\cdots \cdots\end{array}$ \\
\hline $27340^{1}$ & $\begin{array}{l}5 \text { lbs. lead arsenate } \\
\text { (powder), 50 galls. } \\
\text { water.11 } \\
3 \text { bs. lead arsenate } \\
\text { (powder), 50 galls. } \\
\text { water. }{ }^{2} \text {. }\end{array}$ & $\begin{array}{l}\text { June } 28, \text { Aug. } \\
1 . \\
\text { Aug. } 19 .\end{array}$ & $\begin{array}{l}\text { Unwashed . } \\
\text { Washed } 7 . .\end{array}$ & $\begin{array}{l}3.9 \\
1.5\end{array}$ & $\begin{array}{l}30.7 \\
11.8\end{array}$ & $\begin{array}{l}19.1 \\
11.5\end{array}$ & $\begin{array}{r}150.4 \\
90.6\end{array}$ & & & $\begin{array}{l}87.3 \\
\cdots . .\end{array}$ \\
\hline $27346^{1}$ & $\begin{array}{l}\text { 4-5-50 Bordeaux, } 2 \text { lbs. } \\
\text { resin fish-oil soap. } 9\end{array}$ & $\begin{array}{l}\text { June } 24, \text { Aug. } \\
3 .\end{array}$ & $\begin{array}{l}\text { Unwashed . } \\
\text { Washed }{ }^{7} \text {... }\end{array}$ & & & $\ldots .$. & & $\begin{array}{l}3.0 \\
1.6\end{array}$ & $\begin{array}{l}23.4 \\
12.5\end{array}$ & 87.2 \\
\hline 2734710 & $\begin{array}{l}10 \text { lbs. lead arsenate } \\
\text { (p a s t e), } 50 \text { galls. } \\
\text { water. }{ }^{11}\end{array}$ & July 222 & $\begin{array}{l}\text { Unwashed. } \\
\text { Washed ? }\end{array}$ & .14 & $\begin{array}{l}1.1 \\
1.1\end{array}$ & $\begin{array}{l}1.4 \\
1.1\end{array}$ & $\begin{array}{r}10.5 \\
8.3\end{array}$ & (n). & ...... & $\begin{array}{l}86.7 \\
\cdots \cdots\end{array}$ \\
\hline 2734810 & $\begin{array}{l}10 \text { lhs. lead arsenate } \\
\text { (paste), } 2 \text { lbs. laundry } \\
\text { soap, } 50 \text { galls. water. it }\end{array}$ & July 22,24 . & $\begin{array}{l}\text { Unwashed. } \\
\text { Washed } 7 \text {... }\end{array}$ & $\begin{array}{l}.15 \\
.09\end{array}$ & $\begin{array}{r}1.2 \\
.7\end{array}$ & $\begin{array}{l}1.5 \\
1.0\end{array}$ & $\begin{array}{r}11.7 \\
7.8\end{array}$ & & & $\begin{array}{r}87.2 \\
\cdots \cdots\end{array}$ \\
\hline $27349^{1}$ & $\begin{array}{l}5 \text { lbs. lead arsenate } \\
\text { (powder), } 50 \text { galls. } \\
\text { water. } \\
3 \text { lbs. lead arsenate } \\
\text { (powder), } 50 \text { galls. } \\
\text { water. }{ }^{2} \text {. }\end{array}$ & $\begin{array}{l}\text { June } 2 \text {, Aug. } \\
\text { 1. } \\
\text { Aug. } 19 .\end{array}$ & $\begin{array}{l}\text { Unwashed . } \\
\text { Washed ?... }\end{array}$ & $\begin{array}{l}3.9 \\
1.4\end{array}$ & $\begin{array}{l}30.7 \\
11.0\end{array}$ & $\begin{array}{l}18.9 \\
12.4\end{array}$ & $\begin{array}{r}148.8 \\
97.7\end{array}$ & & & $\begin{array}{r}87.3 \\
\cdots \cdots\end{array}$ \\
\hline 27181 & Check (iunsprayed) ${ }^{11} \ldots$ & & $\begin{array}{l}\text { Unwashed } \\
\text { Washed }{ }^{7} . .\end{array}$ & $\begin{array}{l}.02 \\
.02\end{array}$ & .14 & $\begin{array}{l}.4 \\
.4\end{array}$ & $\begin{array}{l}2.9 \\
2.9\end{array}$ & 0.9 & $\begin{array}{l}6.4 \\
5.0\end{array}$ & $\begin{array}{r}86.0 \\
\cdots\end{array}$ \\
\hline 28686 & $\begin{array}{l}4 \text { lbs, lead arsenate } \\
\text { (powder), 50 galls. } \\
\text { water, } 2 \text { bs. caustic } \\
\text { potash fish-oil soap. }{ }^{13}\end{array}$ & $\begin{array}{l}\text { June } 26 \text {, July } \\
26,30 \text {. }\end{array}$ & $\begin{array}{l}\text { Unwashed. } \\
\text { Washed }{ }^{7} . .\end{array}$ & $\begin{array}{r}1.1 \\
.6\end{array}$ & $\begin{array}{l}9.6 \\
5.3\end{array}$ & $\begin{array}{l}4.5 \\
2.9\end{array}$ & $\begin{array}{l}39.5 \\
25.4\end{array}$ & & & $\begin{array}{r}88.6 \\
\cdots \cdots\end{array}$ \\
\hline 28685 & Check (unsprayed) ${ }^{13} .$. & & $\begin{array}{l}\text { Unwashed. } \\
\text { Washed } 7 \ldots\end{array}$ & $\begin{array}{l}.01 \\
.01\end{array}$ & .08 & .7 & $\begin{array}{l}5.6 \\
5.6\end{array}$ & $\begin{array}{r}0.6 \\
.6\end{array}$ & $\begin{array}{l}4.8 \\
4.8\end{array}$ & 87.6 \\
\hline 28556 & $\begin{array}{l}\text { 3lbs. lime, } 4 \text { lhs. copper } \\
\text { sulphate, } 2 \text { lbs. resin } \\
\text { fish-oil soap, } 50 \text { galls. } \\
\text { water. }{ }^{13}\end{array}$ & $\begin{array}{l}\text { June } 28, \text { Aug. } \\
\qquad, 20 \text {. }\end{array}$ & $\begin{array}{l}\text { Unwashed } \\
\text { Washed ?... }\end{array}$ & $\begin{array}{l}.01 \\
.1\end{array}$ & $\begin{array}{l}.8 \\
.8\end{array}$ & $\begin{array}{l}.6 \\
.6\end{array}$ & $\begin{array}{l}4.9 \\
4.9\end{array}$ & $\begin{array}{l}.0 \\
1.3 \\
1.2\end{array}$ & $\begin{array}{r}4.8 \\
10.6 \\
9.8\end{array}$ & $\begin{array}{l}87.8 \\
-\cdots\end{array}$ \\
\hline $2 \times \times 30$ & $\begin{array}{l}4 \text { lbs. lead arsenate } \\
\text { (powder), } 2 \text { lbs. caus- } \\
\text { tic potash fish-oil } \\
\text { soap, } 50 \text { galls. water. }{ }^{3}\end{array}$ & $\begin{array}{l}\text { June } 26 \text {, July } \\
26,30 \text {. }\end{array}$ & $\begin{array}{l}\text { Unwashed . } \\
\text { Washed ?... }\end{array}$ & $\begin{array}{r}1.2 \\
.3\end{array}$ & $\begin{array}{r}10.0 \\
2.5\end{array}$ & $\begin{array}{l}4.8 \\
1.9\end{array}$ & $\begin{array}{l}40.0 \\
15.8\end{array}$ & & & $\begin{array}{r}88 . \theta \\
\text { S.6. }\end{array}$ \\
\hline
\end{tabular}

1 Early Black.

Thashed by soaking berries in water for a short time, pouring off the water, adding more water, and repeating operation three times.

8 Harvested Oct. 9, 1916, Brown Mills, N. J.

9 Harvested Sept. 23, 1916, East Wareham, Mass.

io Late Home.

"Harvested Oct. 2, 1916, East Wareham, Mass.

12 Harvested Sept. 25, 1916, East Wareham, Mass.

is Harvested Oet., 1917, East Wareham, Mass. 
Some of the samples from New Jersey reported in Table 11 represent plots which were purposely oversprayed and contain relatively large amounts of spray residues. The lots sprayed according to recommended schedule contain much less spray residue. Samples 27340 and 27349 show a comparatively large amount of spray residue, but these samples are from experimental plots which were sprayed late. The other Massachusetts samples show very little spray residue. The results indicate that when sprayed with the regulation spray and washed before using the berries contain but little spray material.

TABLE 12,-Copper, lead, and arsenic remaining on sprayed grapes at picking time.

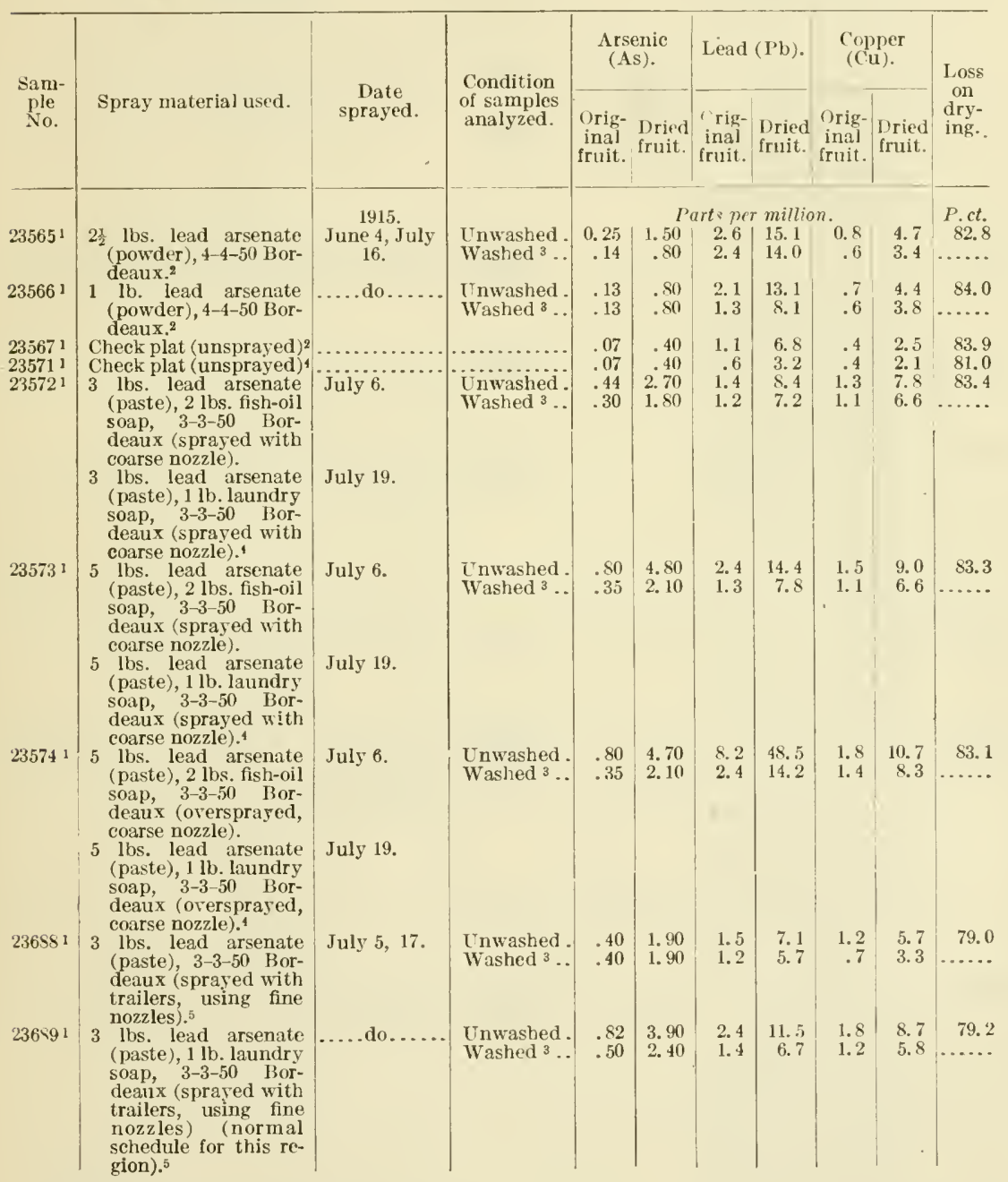

1 Concord.

Harvested Oct. 9, 1915, Benton Harbor, Mich.

- Samples washed in running tap water.

- Harvested Oct. 9, 1915, North East, Pa.

- Harvested Oct. 27, 1915, North East, Pa 
TABLE 12.-Copper, lead, and arsenic remaining on sprayed grapes at picking timeContinued.

\begin{tabular}{|c|c|c|c|c|c|c|c|c|c|c|}
\hline \multirow{2}{*}{$\begin{array}{l}\text { Sam- } \\
\text { ple } \\
\text { No. }\end{array}$} & \multirow{2}{*}{ Spray material used. } & \multirow{2}{*}{$\begin{array}{c}\text { 1)ate } \\
\text { sprayed. }\end{array}$} & \multirow{2}{*}{$\begin{array}{l}\text { Condition } \\
\text { of samples } \\
\text { analyzed. }\end{array}$} & \multicolumn{2}{|c|}{$\begin{array}{l}\text { Arsenic } \\
(\mathrm{As}) \text {. }\end{array}$} & \multicolumn{2}{|c|}{ Lead $(\mathrm{Pb})$. } & \multicolumn{2}{|c|}{$\begin{array}{l}\text { Copper } \\
\text { (Cu). }\end{array}$} & \multirow{2}{*}{$\begin{array}{l}\text { Loss } \\
\text { on } \\
\text { dry- } \\
\text { ing. }\end{array}$} \\
\hline & & & & $\begin{array}{c}\text { ()rig- } \\
\text { inal } \\
\text { fruit. }\end{array}$ & $\begin{array}{l}\text { Drled } \\
\text { fruit. }\end{array}$ & $\begin{array}{l}\text { Orig- } \\
\text { inal } \\
\text { fruit. }\end{array}$ & $\begin{array}{l}\text { Dried } \\
\text { fruit. }\end{array}$ & $\begin{array}{l}\text { (1rig- } \\
\text { inal } \\
\text { fruit. }\end{array}$ & $\begin{array}{l}\text { i)ried } \\
\text { fruit. }\end{array}$ & \\
\hline \multirow[b]{2}{*}{$23690^{1}$} & \multirow{3}{*}{$\begin{array}{l}3 \text { lbs. lead arsenate } \\
\text { (paste), } 1 \text { lb. laundry } \\
\text { soap, 3-3-50 Bor- } \\
\text { deaux (spray applied } \\
\text { with fine nozzles set } \\
\text { at rear of sprayer). } \\
\text { Check plat (unsprayed) } 6\end{array}$} & \multirow{3}{*}{$\begin{array}{l}1915 . \\
\text { July } 5,17 .\end{array}$} & & \multicolumn{6}{|c|}{ Parts per million. } & P.ct. \\
\hline & & & $\begin{array}{l}\text { Unwashed . } \\
\text { Washed }{ }^{3} \text {.. }\end{array}$ & $\begin{array}{r}0.29 \\
.22\end{array}$ & $\begin{array}{l}1.40 \\
1.00\end{array}$ & $\begin{array}{r}0.9 \\
.4\end{array}$ & $\left|\begin{array}{l}4.3 \\
1.9\end{array}\right|$ & $\begin{array}{r}0.6 \\
.3\end{array}$ & $\begin{array}{l}2.9 \\
1.4\end{array}$ & $\begin{array}{r}79.0 \\
\cdots \cdots\end{array}$ \\
\hline $25836^{1}$ & & & $\begin{array}{l}\text { Unwashed . } \\
\text { Washed }{ }^{3} . .\end{array}$ & .0 & $\begin{array}{l}.0 \\
.0\end{array}$ & $\begin{array}{l}.5 \\
.5\end{array}$ & $\begin{array}{l}2.6 \\
2.6\end{array}$ & $\begin{array}{l}.9 \\
.6\end{array}$ & $\begin{array}{l}4.7 \\
3.2\end{array}$ & $\begin{array}{l}81.0 \\
\cdots \cdots\end{array}$ \\
\hline $25837^{1}$ & $\begin{array}{l}1 \text { gall.lime-sulphur, } 33^{3} \\
\text { B.), } 7 \text { galls. Water. } \\
\mathbf{4 - 4 0} \text {-50rdeaux } 6 \ldots . .\end{array}$ & $\begin{array}{l}1916 \text {. } \\
\text { Dormant } \\
\text { spray. } \\
\text { June } 16 \text {. }\end{array}$ & $\begin{array}{l}\text { Unwashed. } \\
\text { Washed }^{3} \ldots 1\end{array}$ & $\begin{array}{l}.05 \\
.02\end{array}$ & $\begin{array}{l}.26 \\
.10\end{array}$ & .7 & $\begin{array}{l}3.6 \\
3.1\end{array}$ & $\begin{array}{l}1.1 \\
1.1\end{array}$ & $\begin{array}{l}5.6 \\
5.6\end{array}$ & $\begin{array}{l}80.4 \\
\cdots\end{array}$ \\
\hline 258381 & $\begin{array}{l}8 \text { lbs. Bordeaux (com. } \\
\text { paste), 1 lb. lead arse- } \\
\text { nate (powder), } 50 \\
\text { galls. water. } \\
8 \text { lbs. Bordeaux (com. } \\
\text { paste), } 50 \text { galls.water. }\end{array}$ & June 1,12 . & $\begin{array}{l}\text { Unwashed . } \\
\text { Washed }{ }^{3} \text {.. }\end{array}$ & $\begin{array}{l}.12 \\
.07\end{array}$ & $\begin{array}{l}.63 \\
.37\end{array}$ & $\begin{array}{l}.8 \\
.6\end{array}$ & $\begin{array}{l}\text { 4. } 2 \\
3.2\end{array}$ & $\begin{array}{l}1.4 \\
1.1\end{array}$ & $\begin{array}{l}7.4 \\
5.8\end{array}$ & $\begin{array}{l}81.1 \\
8 . .\end{array}$ \\
\hline 259031 & Check plat (unsprayed)? & & $\begin{array}{l}\text { Unwashed. } \\
\text { Washed }{ }^{3} .\end{array}$ & $\begin{array}{l}.04 \\
.04\end{array}$ & $\begin{array}{l}.17 \\
.17\end{array}$ & $\begin{array}{l}.6 \\
.6\end{array}$ & $\begin{array}{l}2.6 \\
2.6\end{array}$ & $\begin{array}{l}.8 \\
.4\end{array}$ & $\begin{array}{l}3.4 \\
1.7\end{array}$ & $\begin{array}{l}76.5 \\
\ldots \ldots\end{array}$ \\
\hline 259041 & $\begin{array}{l}1 \text { lb. soap, } 1 \frac{\text { l lbs. lead }}{2} \text { arsenate (powder), } \\
3-3-50 \text { B or de aux } \\
\text { (used trailers with } \\
\text { medium nozzles).7 }\end{array}$ & July 6, 21 . & $\begin{array}{l}\text { Unwashed. } \\
\text { Washed }{ }^{3} \text {.. }\end{array}$ & $\begin{array}{l}3.00 \\
1.00\end{array}$ & $\begin{array}{r}12.60 \\
4.20\end{array}$ & $\begin{array}{l}7.5 \\
3.5\end{array}$ & $\begin{array}{l}31.6 \\
14.8\end{array}$ & $\begin{array}{l}4.1 \\
1.4\end{array}$ & $\begin{array}{r}17.3 \\
5.9\end{array}$ & $\begin{array}{l}76.3 \\
\cdots \cdots\end{array}$ \\
\hline 25905 ᄂ & $\begin{array}{l}1 \text { lb. soap, } 2 \text { lbs. lead } \\
\text { arsenate (powder), } \\
3-3-50 \text { Bordeaux } \\
\text { (used trailers with } \\
\text { medium nozzles) }{ }^{7}\end{array}$ & .....do.... & $\begin{array}{l}\text { Unwashed. } \\
\text { Washed }{ }^{3} \text {.. }\end{array}$ & $\begin{array}{l}.70 \\
.60\end{array}$ & $\begin{array}{l}3.20 \\
2.70\end{array}$ & $\begin{array}{l}3.9 \\
2.8\end{array}$ & $\begin{array}{l}17.7 \\
12.7\end{array}$ & $\begin{array}{l}2.1 \\
1.3\end{array}$ & $\begin{array}{l}9.5 \\
5.5\end{array}$ & $\begin{array}{r}78.0 \\
\cdots \cdots\end{array}$ \\
\hline $25906^{1}$ & $\begin{array}{l}1 \text { lb. soap, } 21 \text { lbs. lead } \\
\text { arsenate (powder), } \\
3-3-50 \text { B or deaux } \\
\text { (used trailers with } \\
\text { medium nozzles). } \\
1 \text { lb. lime, } 1 \text { lb. soap, } 2 . \\
\text { lbs. lead arsenate } \\
\text { (powder), } 50 \text { galls. } \\
\text { water (double appli. } \\
\text { cation). } 7\end{array}$ & .....do....... & $\begin{array}{l}\text { Unwashed. } \\
\text { Washed }{ }^{3} \text {.. }\end{array}$ & $\begin{array}{l}3.80 \\
2.60\end{array}$ & $\begin{array}{l}16.10 \\
11.00\end{array}$ & $\begin{array}{r}12.0 \\
7.6\end{array}$ & $\begin{array}{l}50.8 \\
32.2\end{array}$ & $\begin{array}{l}3.2 \\
1.7\end{array}$ & $\begin{array}{r}13.6 \\
7.2\end{array}$ & $\begin{array}{l}76.4 \\
\cdots \cdots\end{array}$ \\
\hline 259071 & $\begin{array}{l}1 \text { lb. soap, } 1 \frac{1}{2} \text { lbs. lead } \\
\text { arsenate (powder), } \\
3-3-50 \text { B or d e a ux } \\
\text { (used trailers with } \\
\text { fine nozzle). }\end{array}$ & July 6.21. & $\begin{array}{l}\text { Unwashed. } \\
\text { Washed }{ }^{3} . . .\end{array}$ & $\begin{array}{l}.30 \\
.30\end{array}$ & $\begin{array}{l}1.30 \\
1.30\end{array}$ & $\begin{array}{l}2.4 \\
1.3\end{array}$ & $\begin{array}{r}10.3 \\
5.6\end{array}$ & $\begin{array}{l}2.3 \\
1.5\end{array}$ & $\begin{array}{l}9.8 \\
6.5\end{array}$ & $\begin{array}{r}76.6 \\
\cdots \cdots\end{array}$ \\
\hline $26016^{8}$ & $\begin{array}{l}\text { 4-3-50 Bordeaux (me- } \\
\text { dium set nozzle) }\end{array}$ & June 15. & $\begin{array}{l}\text { Unwashed. } \\
\text { Washed }{ }^{3} \ldots\end{array}$ & $\begin{array}{l}.15 \\
.15\end{array}$ & $\begin{array}{r}.60 \\
.60 \\
\end{array}$ & $\begin{array}{r}.7 \\
.7\end{array}$ & $\begin{array}{l}2.9 \\
2.9\end{array}$ & $\begin{array}{l}2.0 \\
1.3\end{array}$ & $\begin{array}{r}8.3 \\
5.4\end{array}$ & $\begin{array}{r}75.8 \\
-: \cdot\end{array}$ \\
\hline $26017^{8}$ & $\begin{array}{l}\text { 4-3-50 Bordeaux (ne- } \\
\text { dium set nozzle). } \\
2 \frac{1}{2} \text { llss. lead arsenate } \\
\text { (powder), } 2 \text { lbs. laun- } \\
\text { dry soap, 3-3-50 Bor- } \\
\text { deaux (sprayed with } \\
\text { trailer, fine nozzle). } \\
2 \frac{1}{2} \text { lbs. lead arsenate } \\
\text { (powder), } 1 \text { lb. resin } \\
\text { soap, 3-3-50 Bor- } \\
\text { deaux (sprayed with } \\
\text { trailer, fine nozzle) }{ }^{9}\end{array}$ & $\begin{array}{l}\text {.... do...... } \\
\text { June } 28 .\end{array}$ & $\begin{array}{l}\text { Unwashed. } \\
\text { Washed }{ }^{3} . .\end{array}$ & $\begin{array}{r}.80 \\
.70\end{array}$ & $\begin{array}{l}7.30 \\
2.80\end{array}$ & $\begin{array}{l}5.1 \\
2.1\end{array}$ & $\begin{array}{r}20.7 \\
8.5\end{array}$ & $\begin{array}{l}1.3 \\
2.7 \\
1.5\end{array}$ & $\begin{array}{r}11.0 \\
6.1\end{array}$ & $\begin{array}{r}75.4 \\
\cdots \cdots\end{array}$ \\
\hline $26018^{8}$ & $\begin{array}{l}\text { 4-3-50 Bordeaux (me- } \\
\text { dium set nozzle). } \\
21 \text { lbs. lead arsenate } \\
\text { (powder), 2 lbs. laun- } \\
\text { dry soap, 3-3-50 Bor- } \\
\text { deaux (sprayed with } \\
\text { trailer, coarse nozle). } \\
2 \frac{1}{2} \text { lbs. lead arsenate } \\
\text { (powder), 1 lb. resin } \\
\text { soap, 3-3-50 Bor- } \\
\text { deaux (sprayed with } \\
\text { trailer, coarse nozzle) }\end{array}$ & $\begin{array}{l}\text { June } 15 . \\
\text { June } 28 .\end{array}$ & $\begin{array}{l}\text { Unwashed. } \\
\text { Washed }^{3} . .\end{array}$ & $\begin{array}{r}3.70 \\
.90\end{array}$ & $\begin{array}{r}16.30 \\
4.00\end{array}$ & $\begin{array}{r}10.4 \\
3.1\end{array}$ & $\begin{array}{l}45.8 \\
13.7\end{array}$ & $\begin{array}{l}3.4 \\
1.4\end{array}$ & $\begin{array}{r}15.0 \\
6.2\end{array}$ & $\begin{array}{r}77.3 \\
\cdots \cdots\end{array}$ \\
\hline $\begin{array}{ccc}1 & 1 \\
3 \\
3 \\
6 \\
1\end{array}$ & $\begin{array}{l}\text { acord. } \\
\text { mples washed in rumning } \\
\text { rvested Oet. }: 77,1915, \text { No } \\
\text { rvested Sept. 30, 1916, Be }\end{array}$ & $\begin{array}{l}\text { orth East, P } \\
\text { enton Harb }\end{array}$ & & 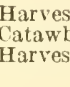 & $\begin{array}{l}\text { ba. } \\
\text { sted Oc }\end{array}$ & t. 13,1 & $916, \mathrm{Sa}$ & $\begin{array}{l}\text { orth Ea: } \\
\text { andusk }\end{array}$ & $\begin{array}{l}\text { ast, } \mathrm{Pa} \text {. } \\
\mathrm{ky}, \mathrm{Ohi}\end{array}$ & \\
\hline
\end{tabular}


TABLE 12.-Copper, lead, and arsenic remaining on sprayed grapes at picking timeContinued.

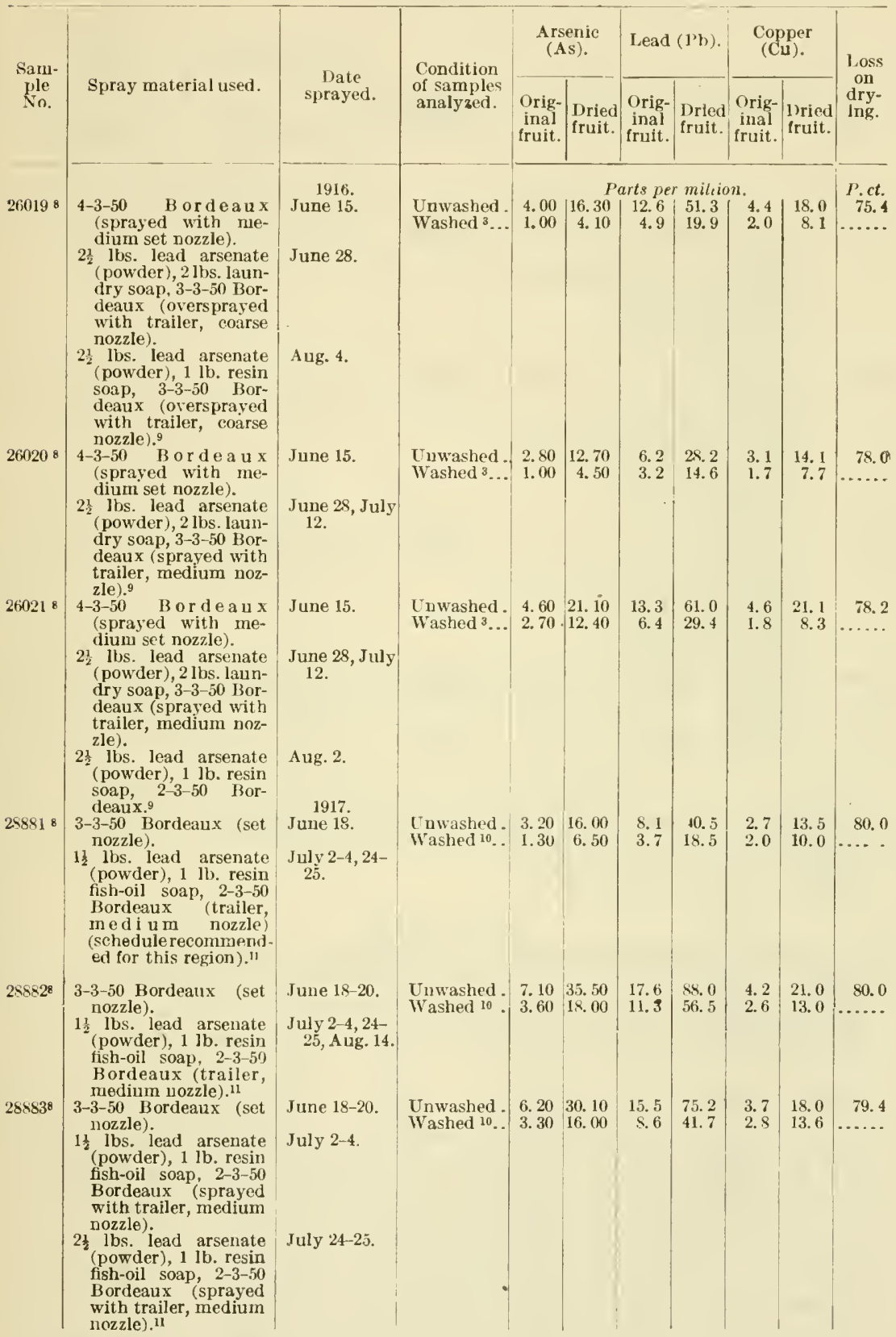

3 Samples washed in running tap water.

8 Catawba.

9 Harvested Oct. 13, 1916, Sandusky, Ohio.

10 Samples washed by soaking the grapes in water for 5 minutes, pouriug off the water, and theu washing In running tap water.

11 Harvested Oct. 27, 1917, Sandusky, Ohio. 
TABLE 12.-Copper, lead, and arsenic remaining on sprayed grapes at picking timeContinued.

\begin{tabular}{|c|c|c|c|c|c|c|c|c|c|c|}
\hline \multirow{2}{*}{$\begin{array}{l}\text { Sam- } \\
\text { ple } \\
\text { No. }\end{array}$} & \multirow{2}{*}{ Spray material used. } & \multirow{2}{*}{$\begin{array}{c}\text { Date } \\
\text { sprayed. }\end{array}$} & \multirow{2}{*}{$\begin{array}{l}\text { Condition } \\
\text { of samples } \\
\text { analyzed. }\end{array}$} & \multicolumn{2}{|c|}{$\begin{array}{l}\text { Arsenie } \\
(\Lambda s)\end{array}$} & \multicolumn{2}{|c|}{ Lead ( J)). } & \multicolumn{2}{|c|}{$\begin{array}{l}\text { Copper } \\
\text { (Cu). }\end{array}$} & \multirow{2}{*}{$\begin{array}{l}\text { Loss } \\
\text { on } \\
\text { dry- } \\
\text { ing. }\end{array}$} \\
\hline & & & & $\begin{array}{l}\text { Orig- } \\
\text { inal } \\
\text { fruit. }\end{array}$ & $\begin{array}{l}\text { Tried } \\
\text { fruit. }\end{array}$ & $\begin{array}{c}\text { Orig- } \\
\text { inal } \\
\text { fruit. }\end{array}$ & $\begin{array}{l}\text { liried } \\
\text { frnit. }\end{array}$ & $\begin{array}{c}\text { Orig- } \\
\text { inal } \\
\text { fruit. }\end{array}$ & $\begin{array}{l}\text { I) ried } \\
\text { fruit. }\end{array}$ & \\
\hline & & 1917. & & \multicolumn{6}{|c|}{ Parts per million. } & P.ct. \\
\hline $28584^{12}$ & $\begin{array}{l}3-3-50 \text { Bordendx } \\
\text { (sprayed with set } \\
\text { nozzle). } \\
2 \frac{1}{2} \text { lbs. lead arsenate } \\
\text { (powder), } 1 \text { lb. resin } \\
\text { fish-oil soap, 2-3-50 } \\
\text { Bordeaux, (sprayed } \\
\text { with trailer, medium } \\
\text { nozzle).13 }\end{array}$ & $\begin{array}{l}\text { June 19-20. } \\
\text { July 2-4.24- } \\
25 .\end{array}$ & $\begin{array}{l}\text { Unwashed. } \\
\text { Washed } 10 .\end{array}$ & $\begin{array}{l}5.70 \\
4.40\end{array}$ & $\begin{array}{l}31.10 \\
24.00\end{array}$ & $\begin{array}{l}13.0 \\
12.0\end{array}$ & $\begin{array}{l}71.0 \\
65.6\end{array}$ & $\begin{array}{l}4.3 \\
3.3\end{array}$ & $\begin{array}{l}23.5 \\
18.0\end{array}$ & $\begin{array}{r}81.7 \\
\cdots \cdots\end{array}$ \\
\hline $28856^{8}$ & $\begin{array}{l}3-3-50 \text { B or d ea } u x \\
\text { (sprayed with set } \\
\text { nozzle). } \\
1 \frac{1}{2} \text { lbs. lead arsenate } \\
\text { (powder), } 1 \text { lb. resin } \\
\text { fisl-oil soap, } 2-3-50 \\
\text { Bordeaux (sprayed } \\
\text { with trailer, medium } \\
\text { nozzle). }{ }^{11}\end{array}$ & $\begin{array}{l}\text { June 19-20. } \\
\text { J ul ly 2-4, } \\
\text { A uig. 14. }\end{array}$ & $\begin{array}{l}\text { Unwashed } \\
\text { Washed }{ }^{10} \text {. }\end{array}$ & $\begin{array}{l}5.90 \\
1.30\end{array}$ & $\begin{array}{r}30.30 \\
6.70\end{array}$ & $\begin{array}{r}14.8 \\
3.9\end{array}$ & $\begin{array}{l}75.9 \\
20.0\end{array}$ & $\begin{array}{l}2.3 \\
1.7\end{array}$ & 11.5 & $\begin{array}{r}80.5 \\
\ldots \ldots .\end{array}$ \\
\hline $28887^{12}$ & $\begin{array}{l}3 \text {-3-50. B ord e a } \mathrm{x} \\
\text { (sprayed with set } \\
\text { nozzle). } \\
1 \text { lb. calcium arsenate } \\
\text { (powder), } 1 \text { lb. resin } \\
\text { fish-oil soap, 2-3-50 } \\
\text { Bordeaux (sprayed } \\
\text { with trailer, medinm } \\
\text { nozzle).13 }\end{array}$ & $\begin{array}{l}\text { June } 18 . \\
\text { July 2-4, 24- } \\
25 \text {. }\end{array}$ & $\begin{array}{l}\text { Unwashed. } \\
\text { Washed }{ }^{10} . .\end{array}$ & $\begin{array}{l}4.60 \\
1.80\end{array}$ & $\begin{array}{r}24.30 \\
9.50\end{array}$ & & & $\begin{array}{l}6.4 \\
4.2\end{array}$ & $\begin{array}{l}33.8 \\
22.2\end{array}$ & $\begin{array}{r}81.1 \\
\cdots \cdots\end{array}$ \\
\hline $28888^{8}$ & $\begin{array}{l}3-3-50 \text { Bordea } u x \\
\text { (sprayed with set } \\
\text { nozzle). } 11\end{array}$ & June 1२-20. & $\begin{array}{l}\text { Unwashed. } \\
\text { Washed } 10 . .\end{array}$ & $\begin{array}{l}.08 \\
.08\end{array}$ & $\begin{array}{r}.40 \\
.40\end{array}$ & $\begin{array}{l}.9 \\
.9\end{array}$ & $\begin{array}{l}4.5 \\
4.5\end{array}$ & $\begin{array}{l}1.5 \\
1.3\end{array}$ & $\begin{array}{l}7.6 \\
6.6\end{array}$ & $\begin{array}{r}30.2 \\
\cdots \cdots\end{array}$ \\
\hline $28889^{12}$ & $\begin{array}{l}3-3-50 \text { B ordea ux } \\
\text { (sprayed with set } \\
\text { nozzle).13 }\end{array}$ & June 18-20. & $\begin{array}{l}\text { Unwashed. } \\
\text { Washed } 10\end{array}$ & $\begin{array}{l}.08 \\
.08\end{array}$ & $\begin{array}{l}.40 \\
.40\end{array}$ & $\begin{array}{l}.5 \\
.3\end{array}$ & $\begin{array}{l}2.5 \\
1.5\end{array}$ & $\begin{array}{l}1.5 \\
1.5\end{array}$ & $\begin{array}{l}7.6 \\
7.6\end{array}$ & $\begin{array}{r}80.2 \\
\ldots .\end{array}$ \\
\hline
\end{tabular}

8 Catan ba.

10 Samples washed by soaking the grapes in water for 5 minutes, pouring ofi the water, and then washing in running tap water.

il Harvested Oct. 27,1917 , Sandusky, Ohio.

12 Ives.

13 Harvested Oct. 18, 1917, Sandusky, Ohio.

WEATHER CONDITIONS.

Nos. 23565-67: Ideal for sprayung during both applications; all foliage and fruit were covered

Nos. 23571-74 and 236s 80 : Heavy ran on July 8 , which seemed to wash off a large amount of the spray material.

Nos. 25836-3x and 25903-07: No abnormal weather conditions reported.

Nos. 26016-21: Dry, hot, clear: season unusually dry.

Nos. 288.1-89: Rainfall normal; in 110 case dul rain interfere with the spraying, nor did rain fall before material was well dried.

The Michigan samples and the Pennsylvania samples mentioned in Table 12 that were sprayed according to normal schedule showed very little spray residne at harrest. Grapes sprayed in Sanduskr, Ohio, according to the schedule formerly used in that region showed a decided spray residue on their surface at harvest. Is this spray residue was no doubt due mainly to late spraying, the Bureau of Entomology has recommended a new schedule which is given under Sample 28881. Table 12 shows the composition of grapes sprayed according to the recommended schedute as compared with that of those sprayed under the schedule formerly used, as well as the composition of grapes sprayed under varions experimental sehedules. 
POISONOUS METALS ON SPRAYED FRUITS AND VEGETABLES.

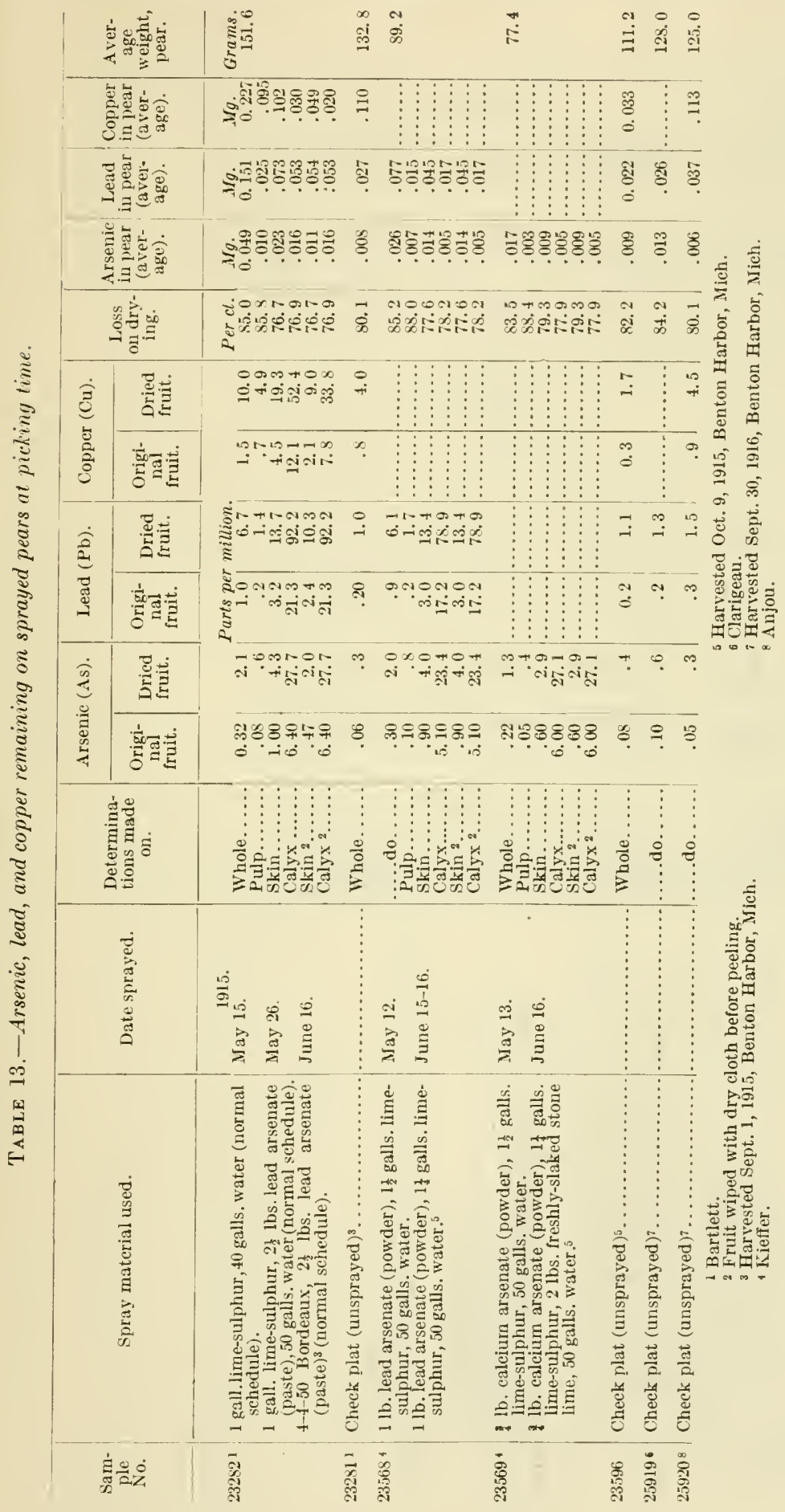




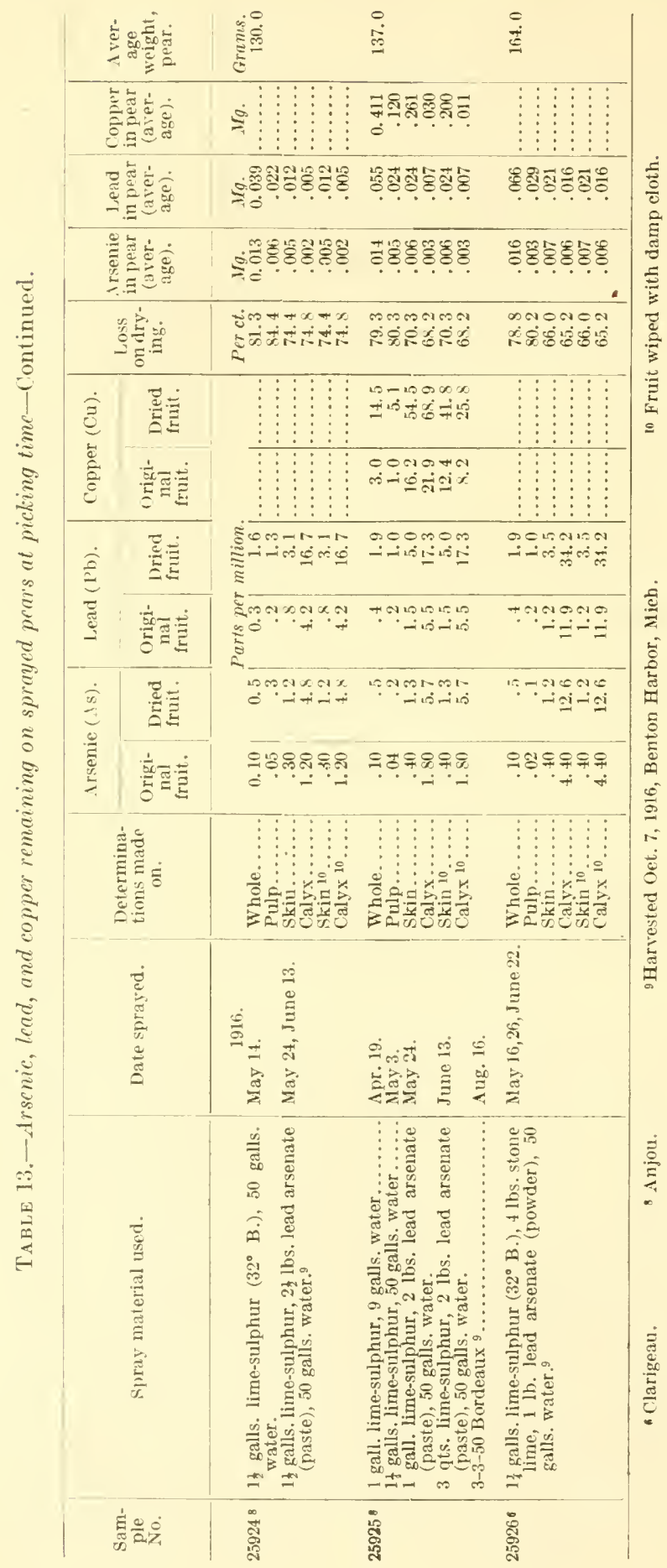


POISONOUS METALS ON SPRAYED FRUITS AND VEGETABLES.

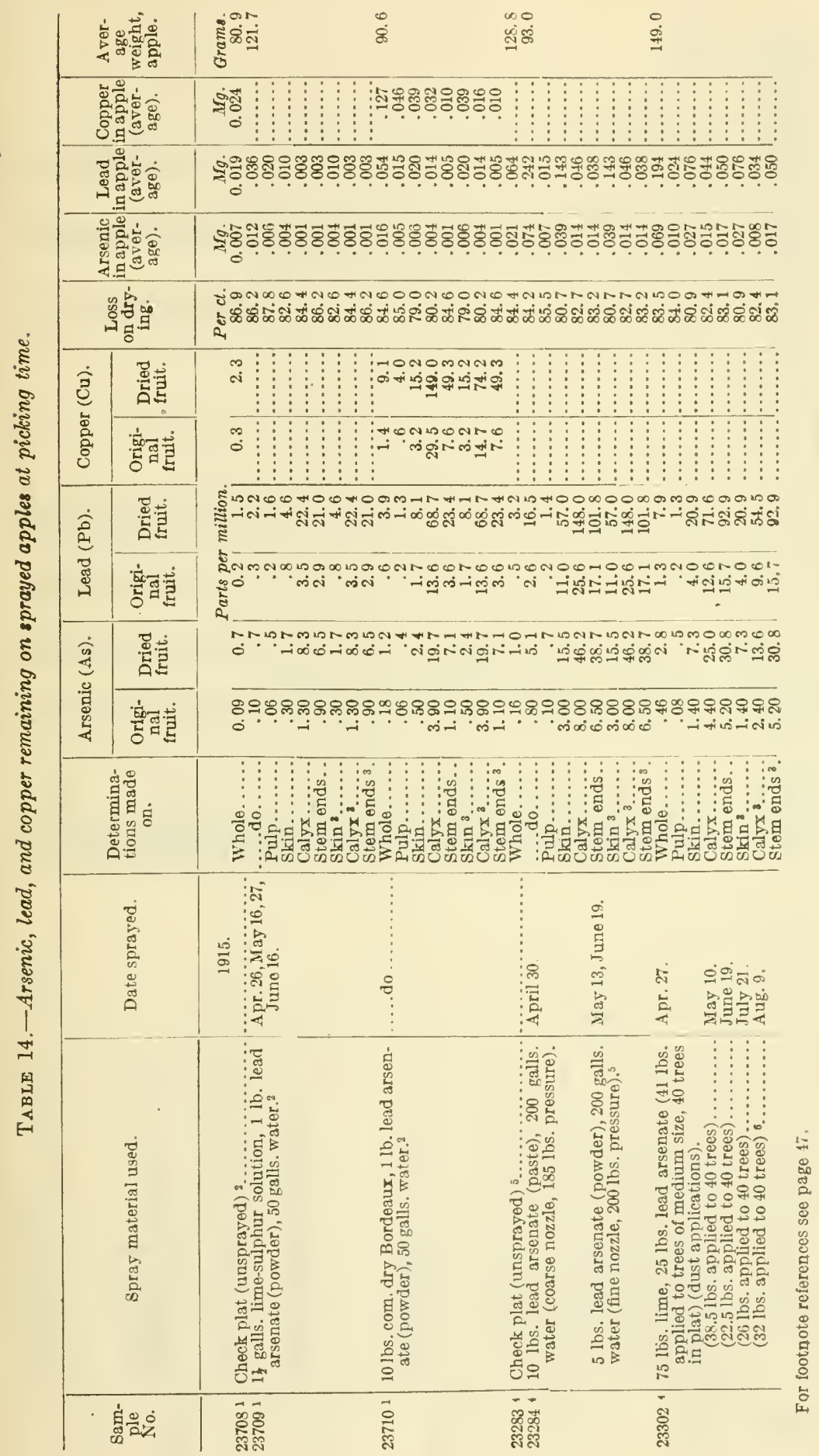

72638-22-Bull. $1027-5$ 


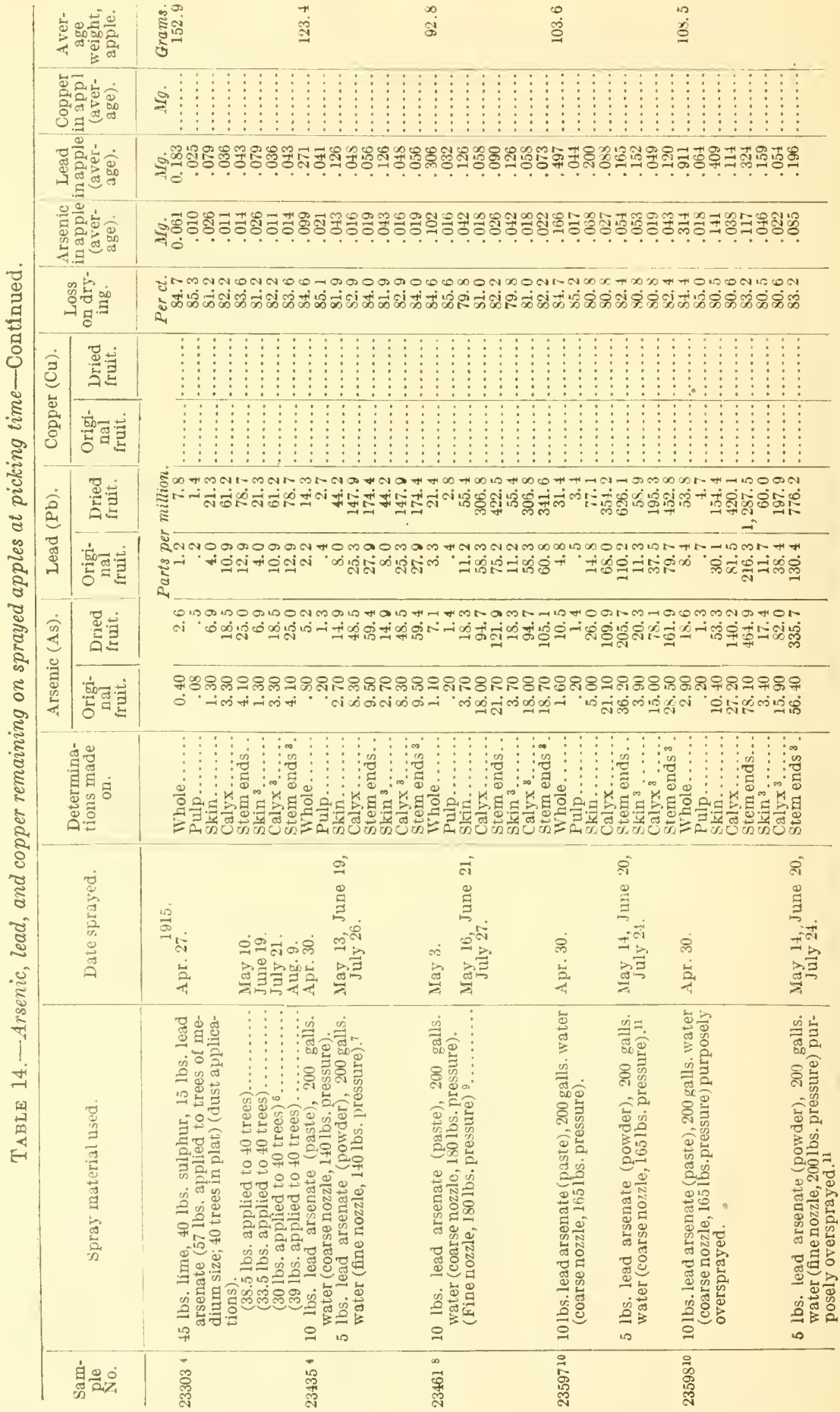


POISONOUS METALS ON SPRAYED FRUITS AND VEGETABLES.

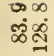
$\stackrel{\infty}{\triangleq}$
$\stackrel{\ddot{\prime}}{\exists}$

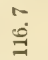
ฐ)
$\stackrel{\bullet}{\stackrel{D}{\exists}}$

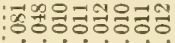

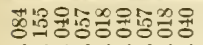

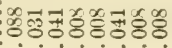

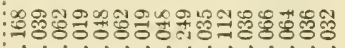

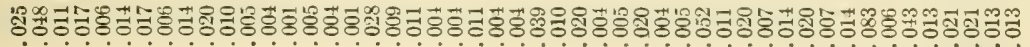

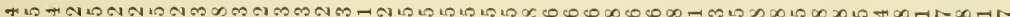

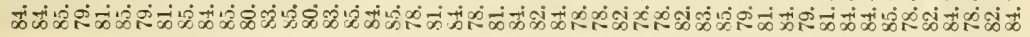

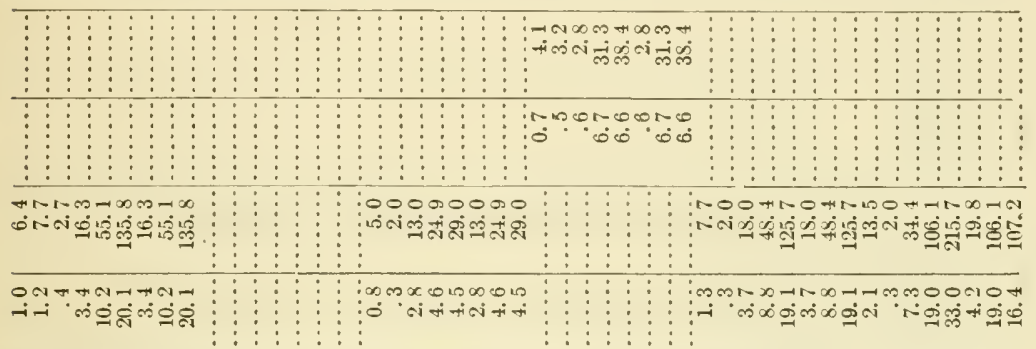

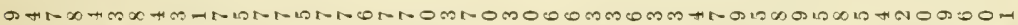
-i - -

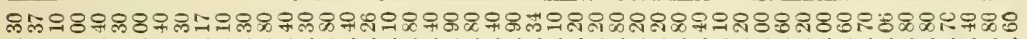

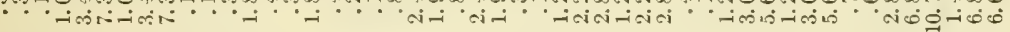

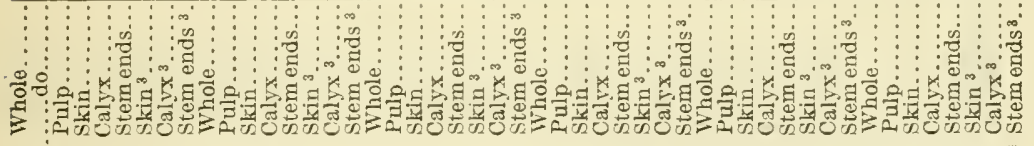

\begin{tabular}{|c|c|c|c|c|c|c|c|c|}
\hline $\begin{array}{l}\vdots \\
\vdots \\
\vdots \\
\vdots \\
\vdots\end{array}$ & 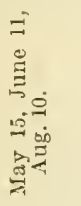 & $\frac{5}{3}$ & 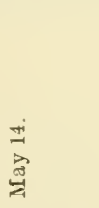 & 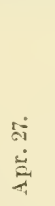 & 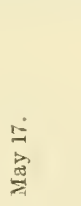 & $\begin{array}{l}\infty \\
\frac{a}{a} \\
\frac{a}{4}\end{array}$ & 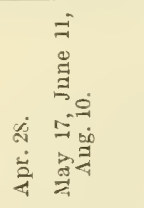 & 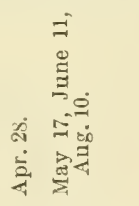 \\
\hline 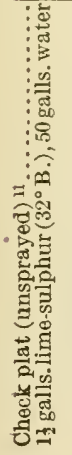 & 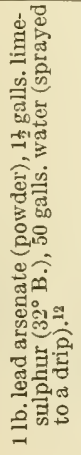 & 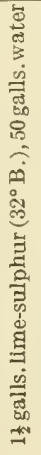 & 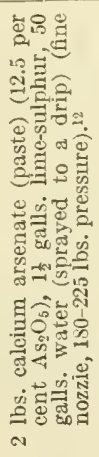 & 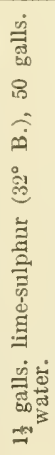 & 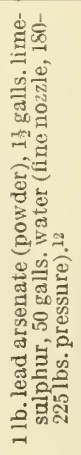 & 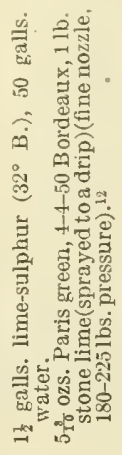 & 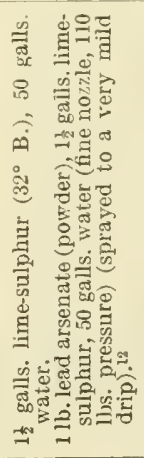 & 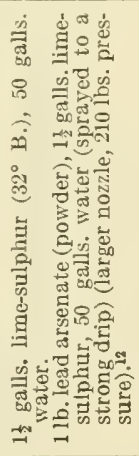 \\
\hline ๙్రొన్స & & 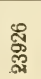 & & 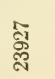 & & $\begin{array}{l}\text { ఎొ } \\
\text { స్స }\end{array}$ & $\begin{array}{l}\text { हొ } \\
\text { ฒొ }\end{array}$ & 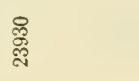 \\
\hline
\end{tabular}




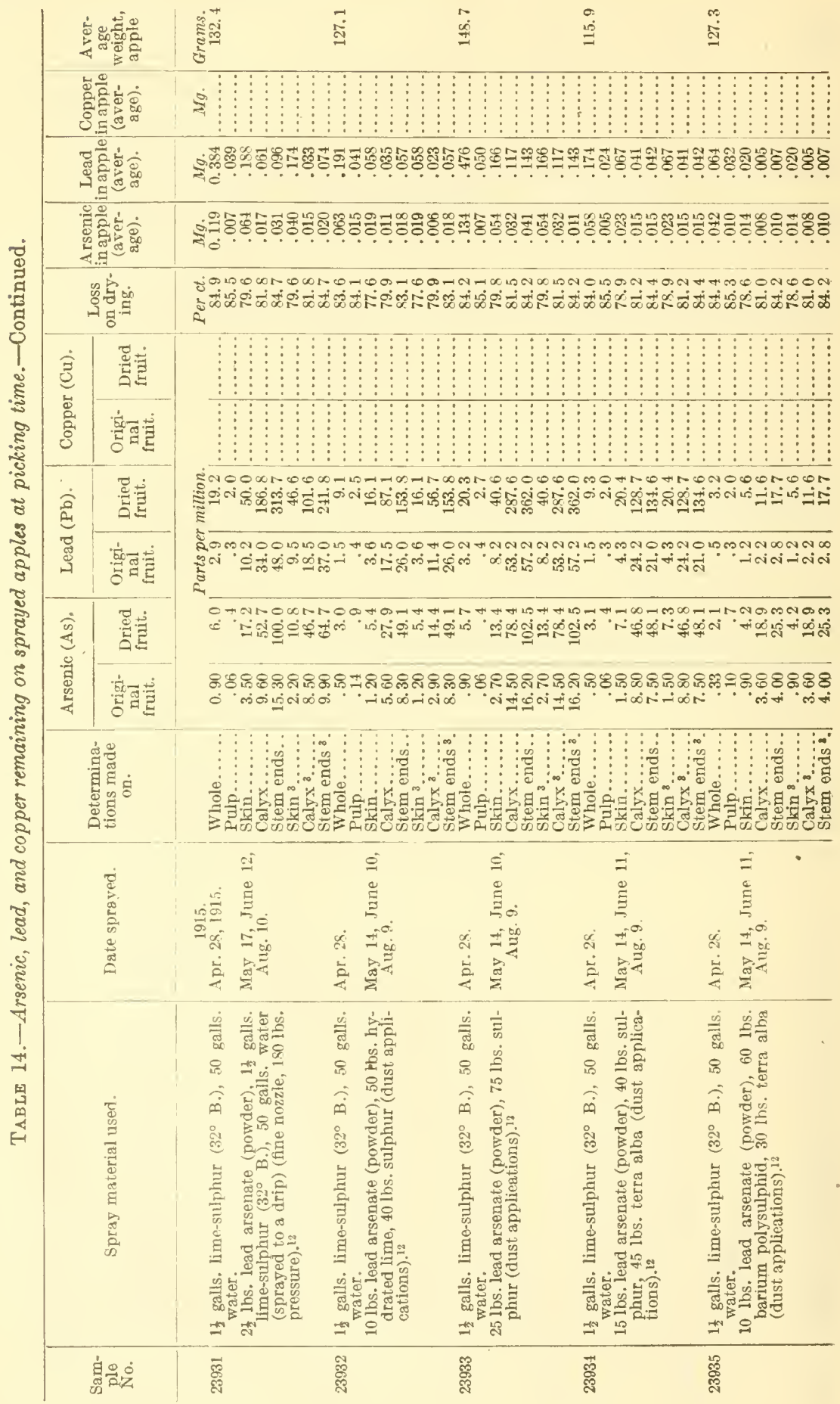


POISONOUS METALS ON SPRAYED FRUITS AND VEGETABLES.

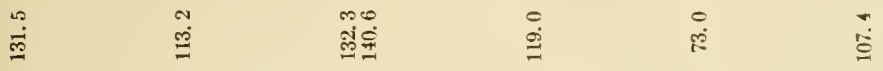

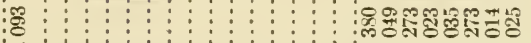

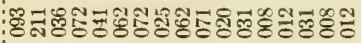

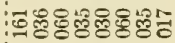

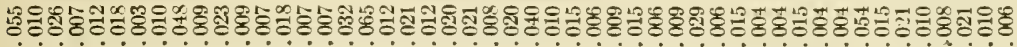

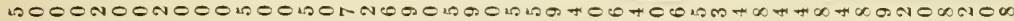

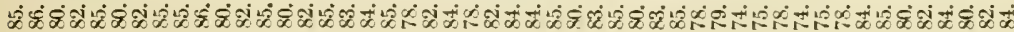

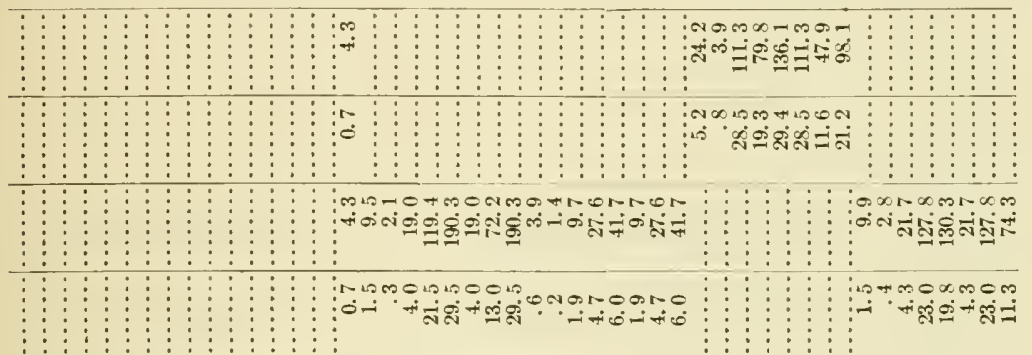

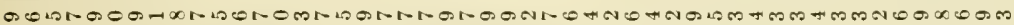

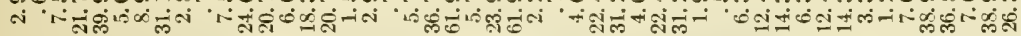

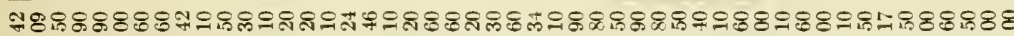

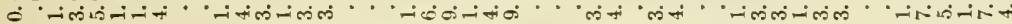

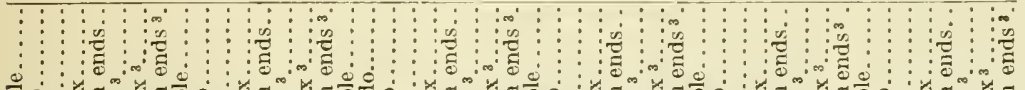
o

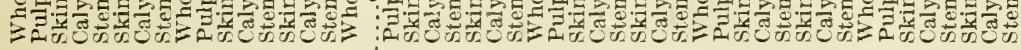

\begin{tabular}{|c|c|c|c|c|c|}
\hline 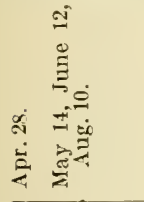 & 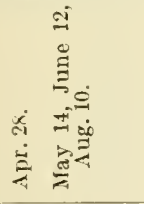 & 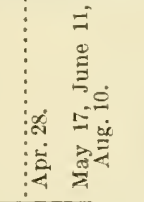 & 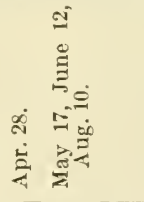 & 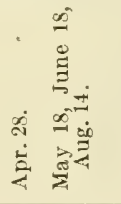 & 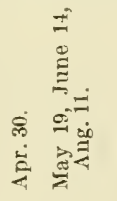 \\
\hline 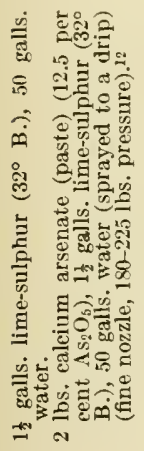 & 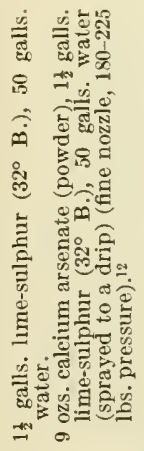 & 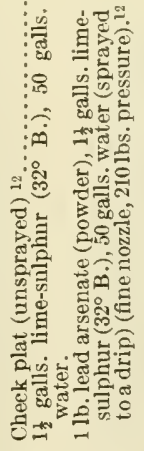 & 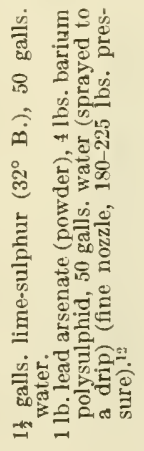 & 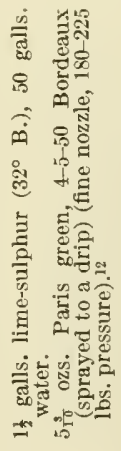 & 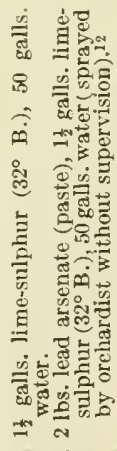 \\
\hline ఝ్ల్టి & 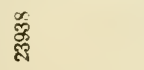 & 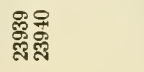 & 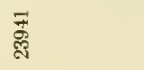 & 䨔 & 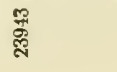 \\
\hline
\end{tabular}




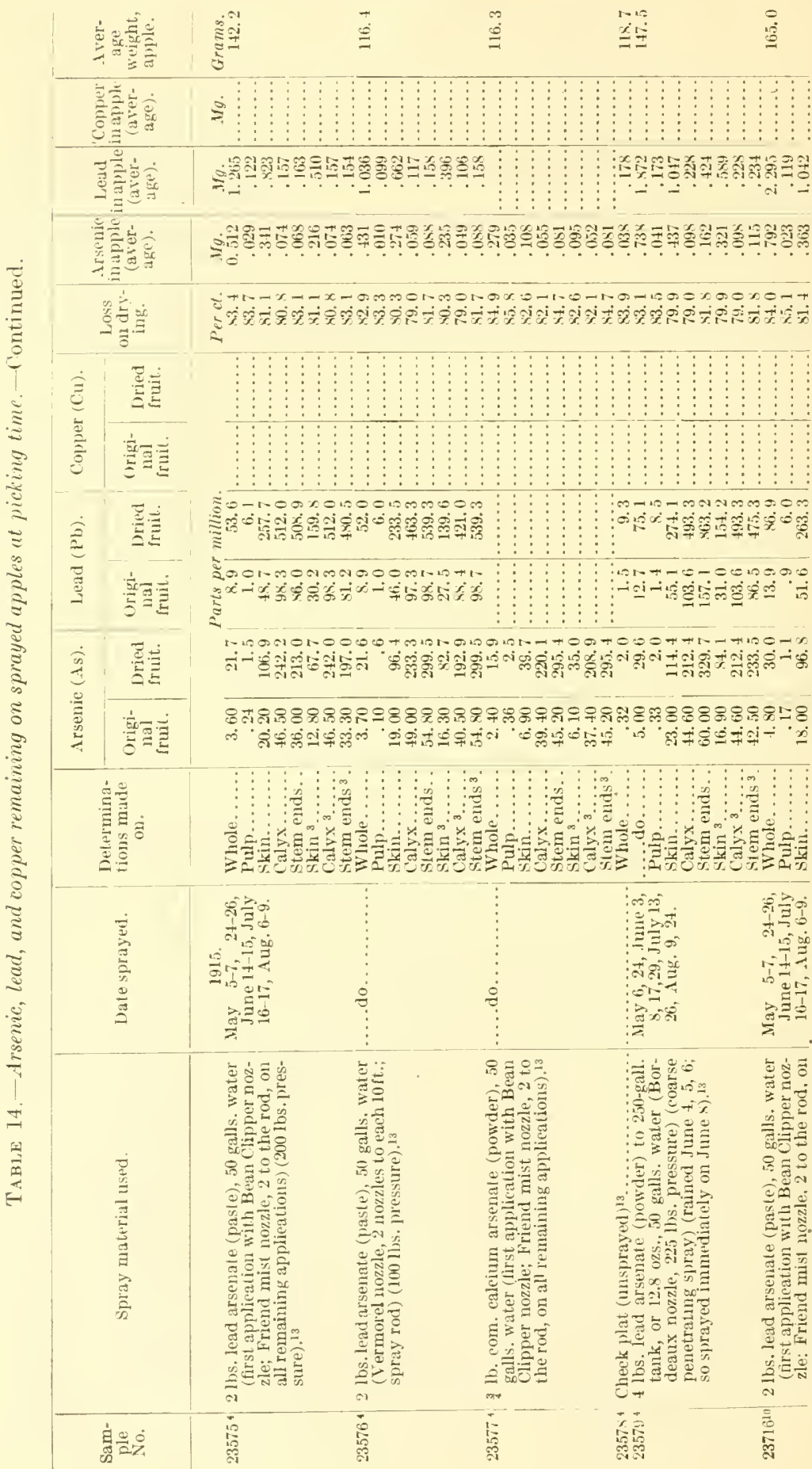




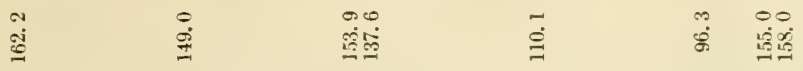

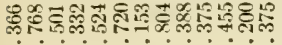

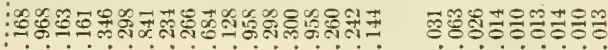

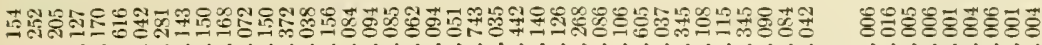

netris onth

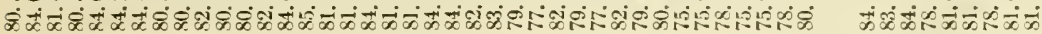

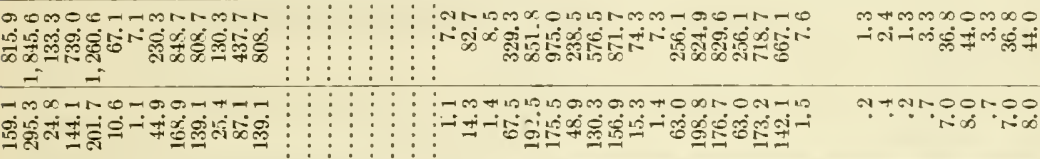

के

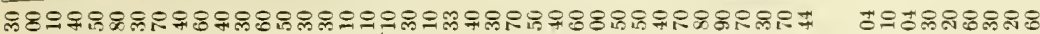

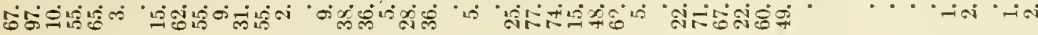

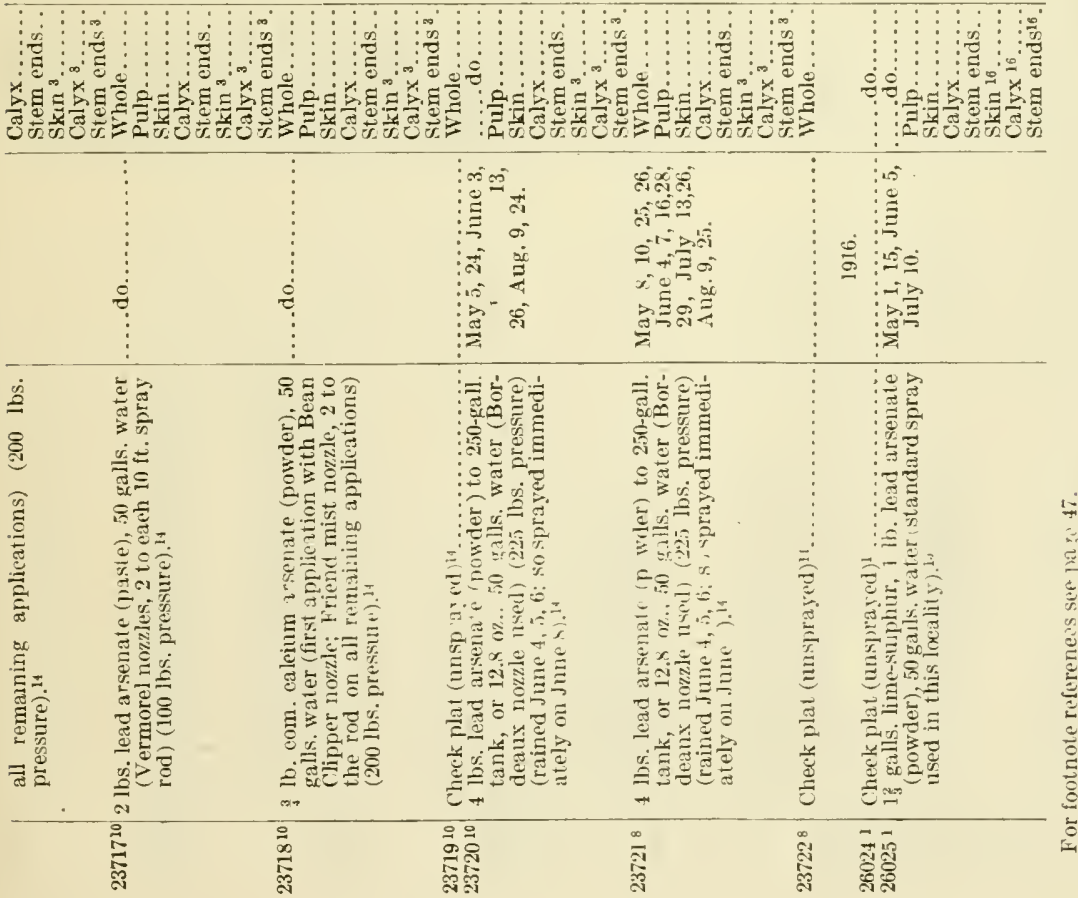




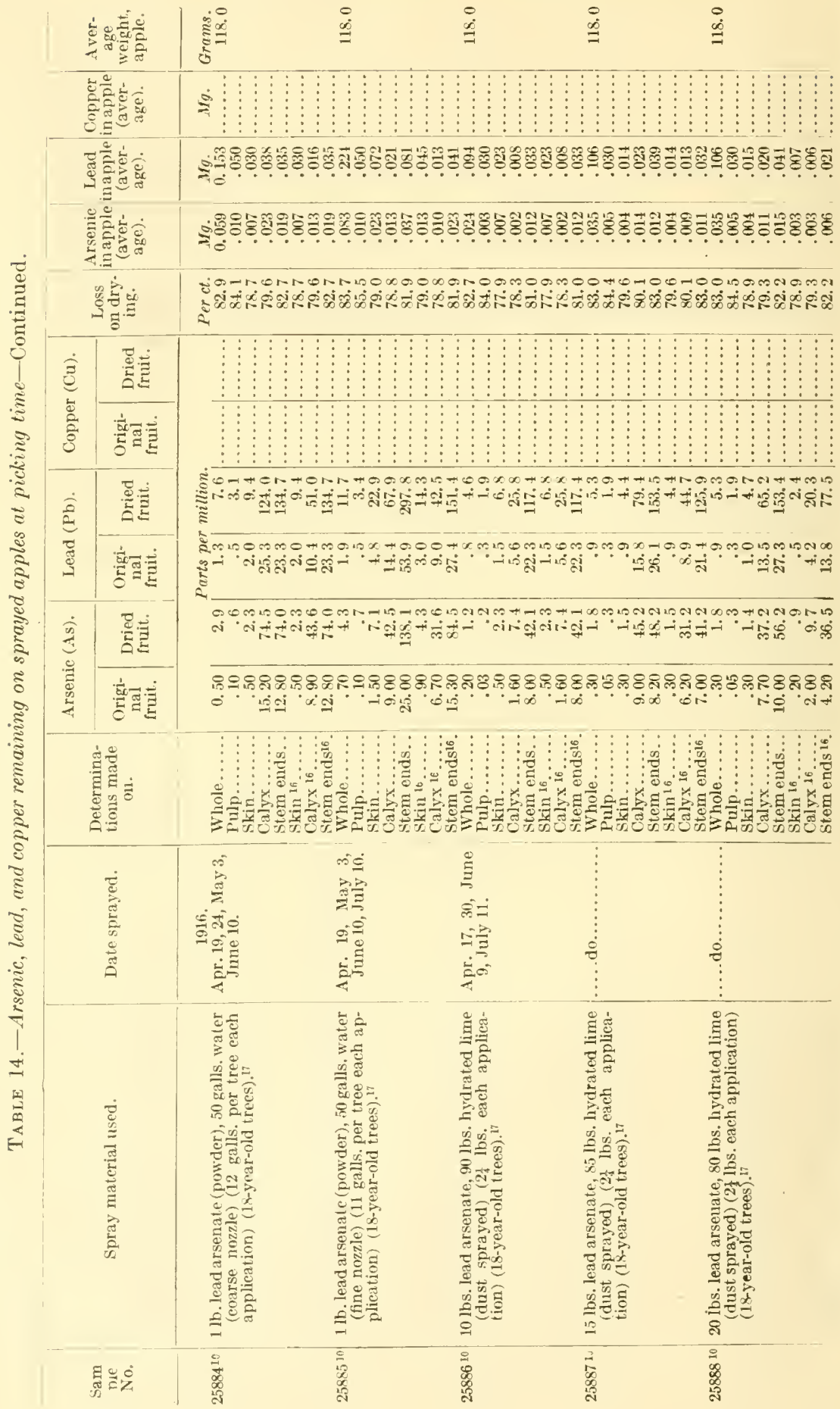




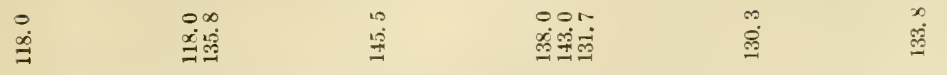

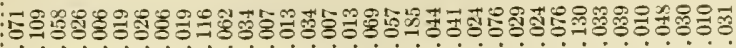

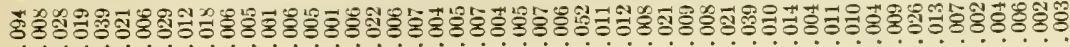

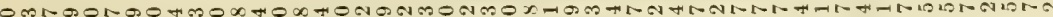

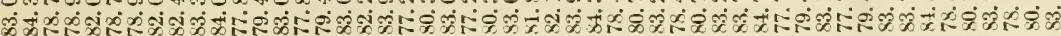

T

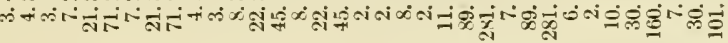

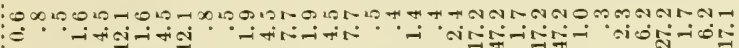

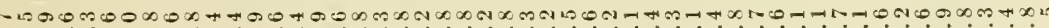

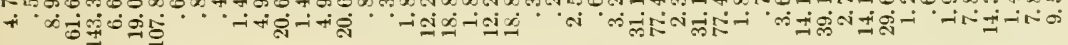

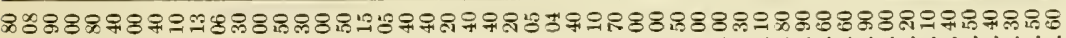
-isiri

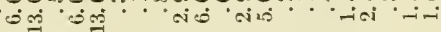

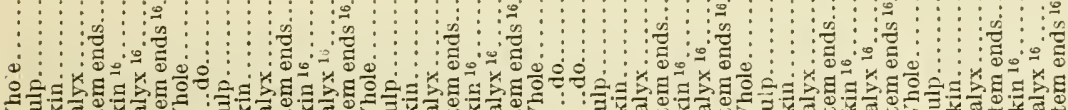

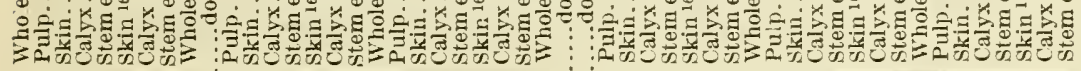

\begin{tabular}{|c|c|c|c|c|c|}
\hline$\dot{0}$ & 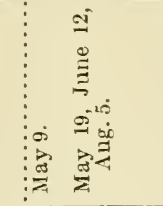 & 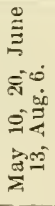 & 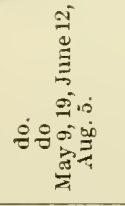 & 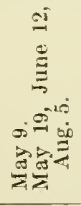 & 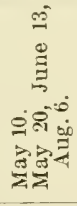 \\
\hline 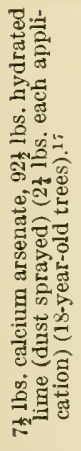 & 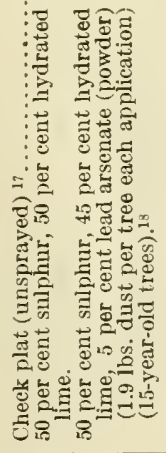 & 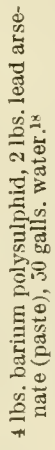 & 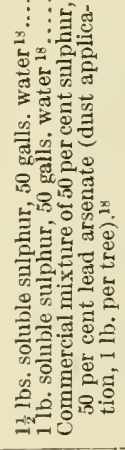 & 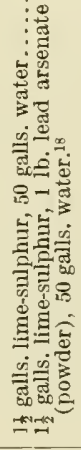 & 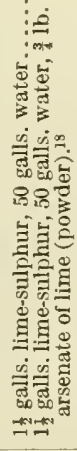 \\
\hline 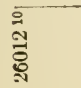 & 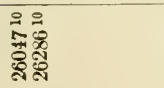 & 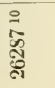 & 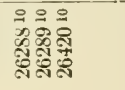 & 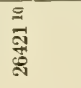 & 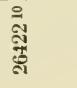 \\
\hline
\end{tabular}


BULLETIN 1027, U. S. DEPARTMENT OF AGRICULTURE.

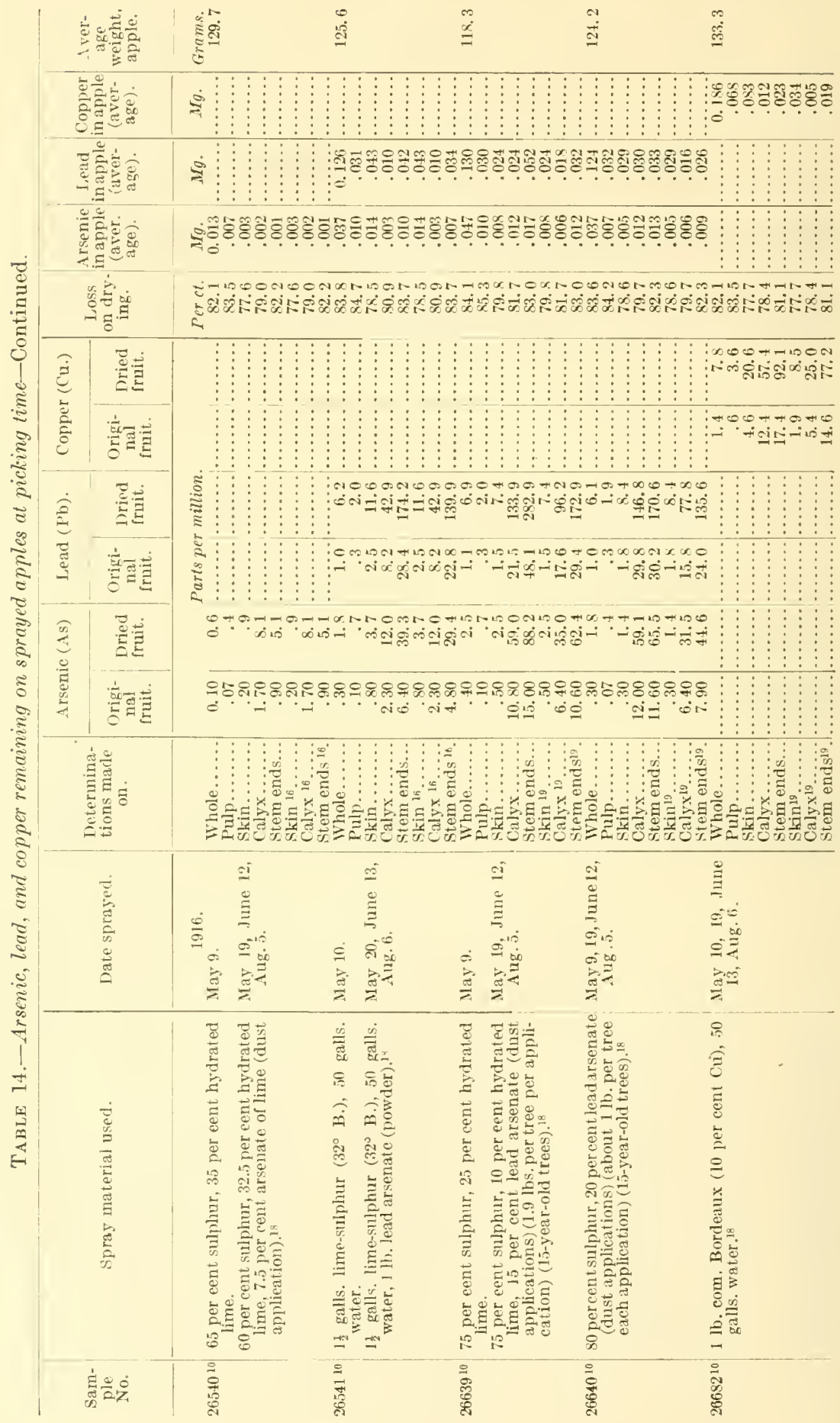


BULLETIN 1027, U. S. DEPARTMENT OF AGRICULTURE.

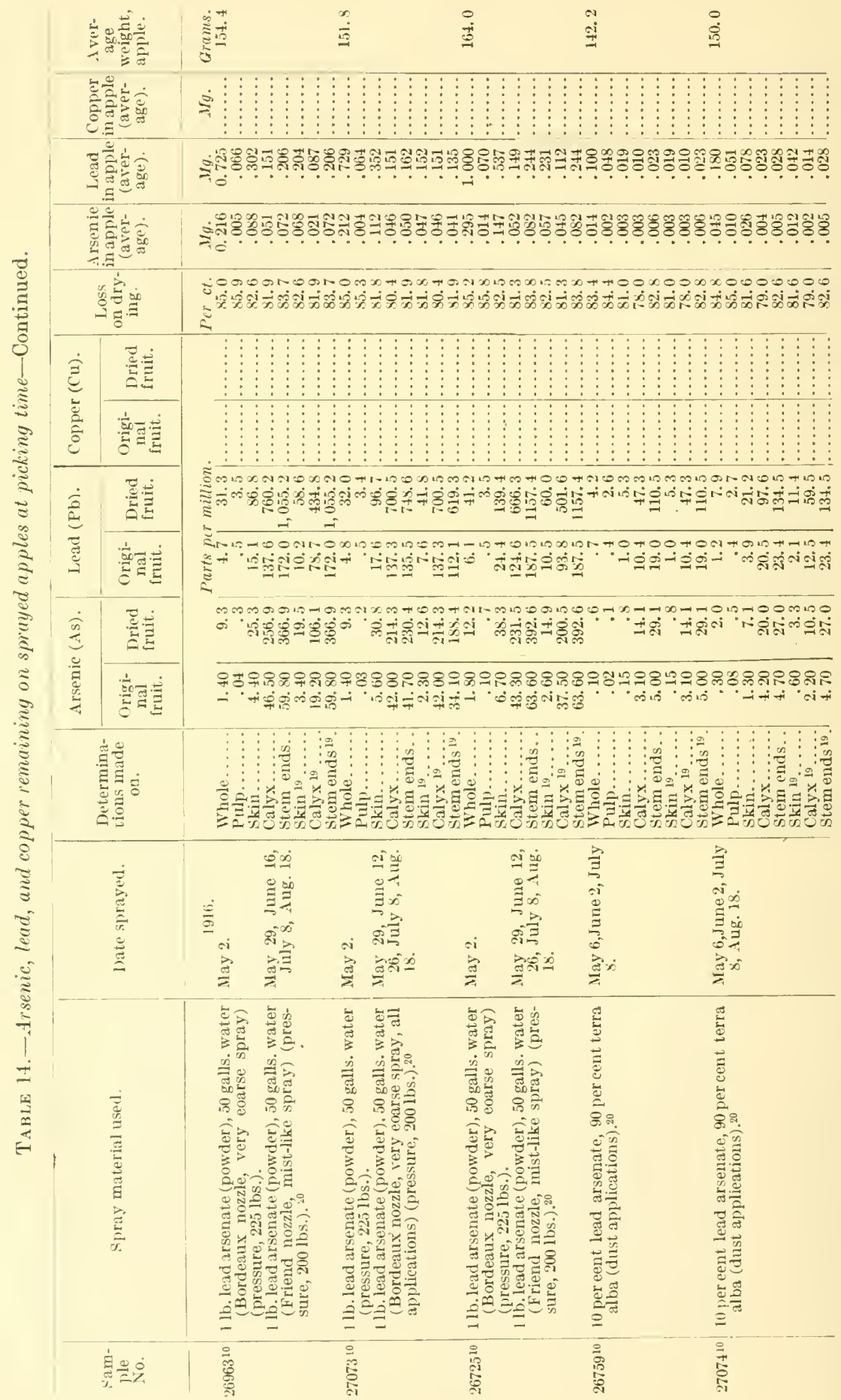




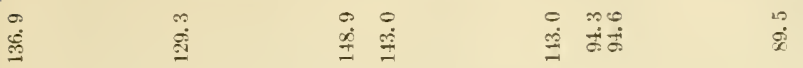

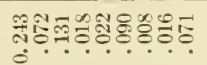

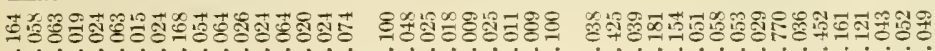

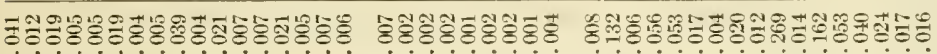

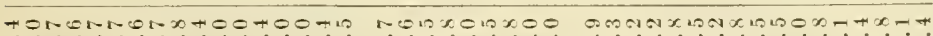

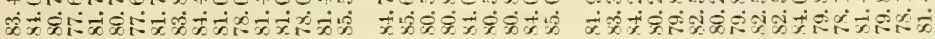

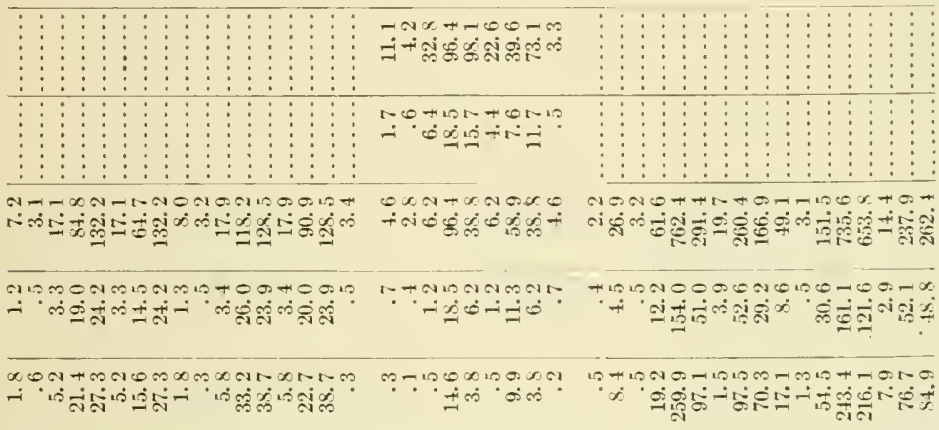

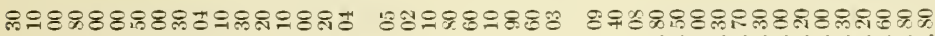
- + in

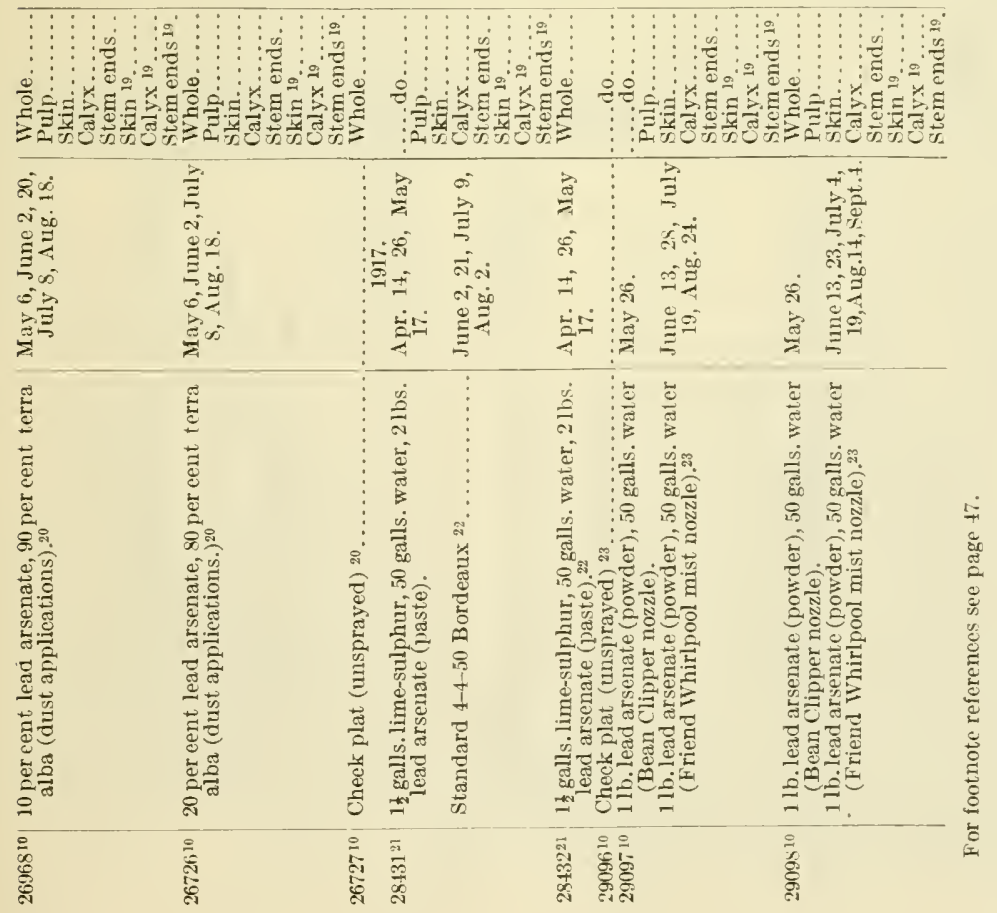




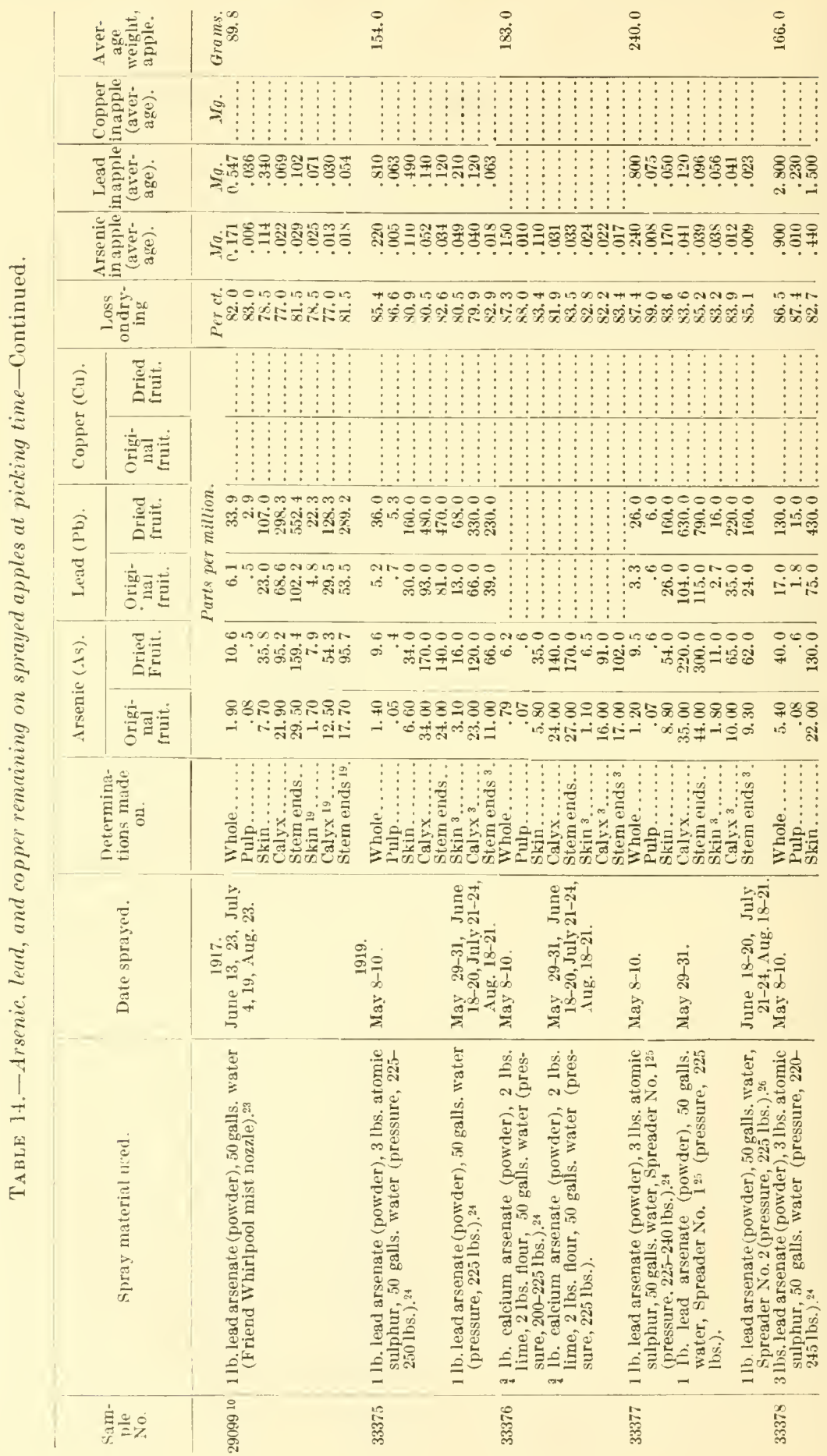




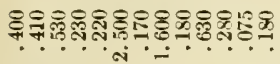

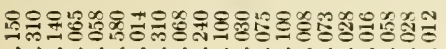

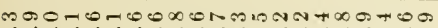

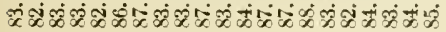

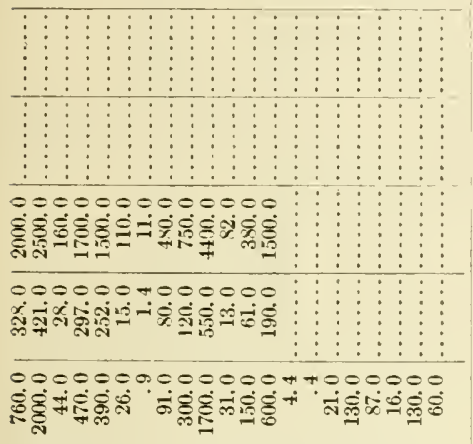

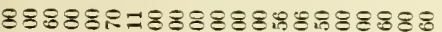

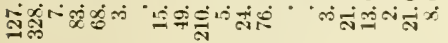

\begin{tabular}{|c|c|c|}
\hline 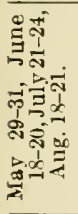 & 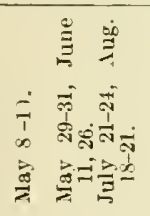 & 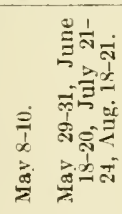 \\
\hline 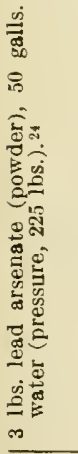 & 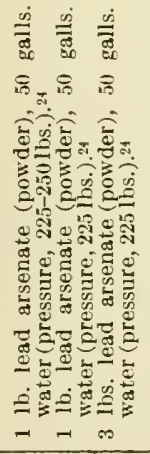 & 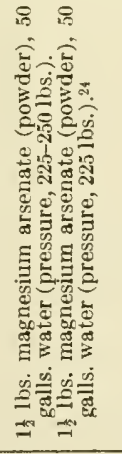 \\
\hline & 串 & 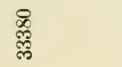 \\
\hline
\end{tabular}

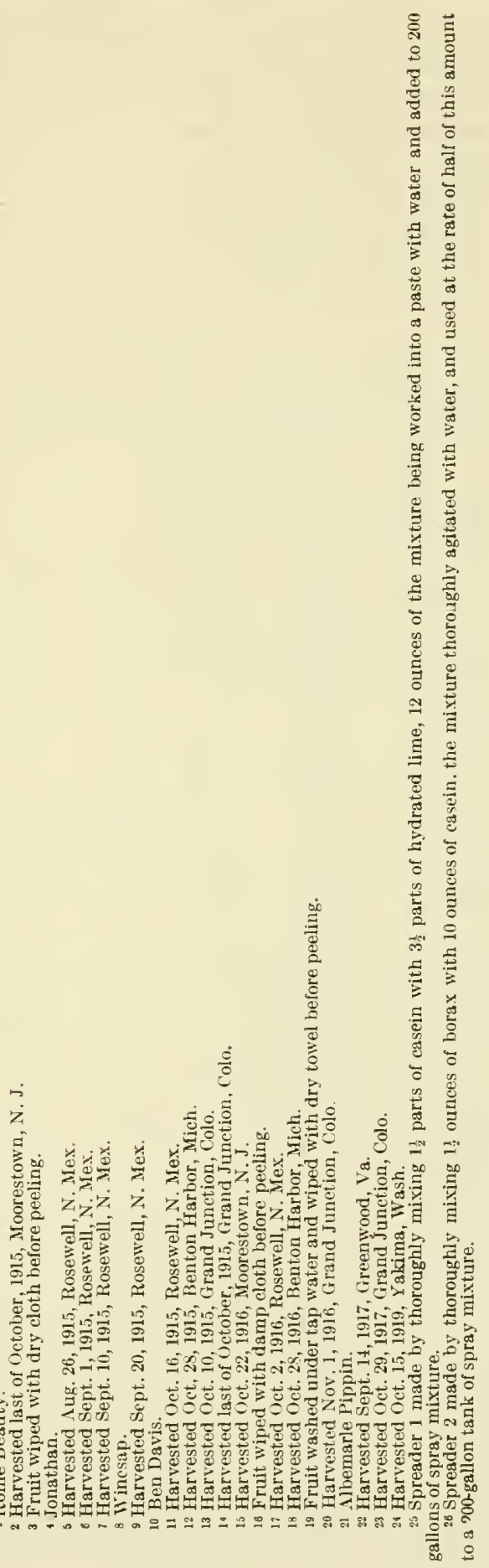


Several spray schedules are represented by the samples shown in Table 14. Very lit tle spray residue was present on the apples, except Samples 23598, 33378, and 33379, which were purposely heavily sprayed, and the apples from Grand Junction, Colo. The 1915 samples from Grand Junction showed so much more residue than the apples from other districts that the spraying schedule was changed in 1916 and 1917, with the result that much less spray residue was found on the fruit.

TABLE 15. - Arsenic, lead, and copper remaining on fruits and vegetables sprayed rith poisonous sprays (summary).

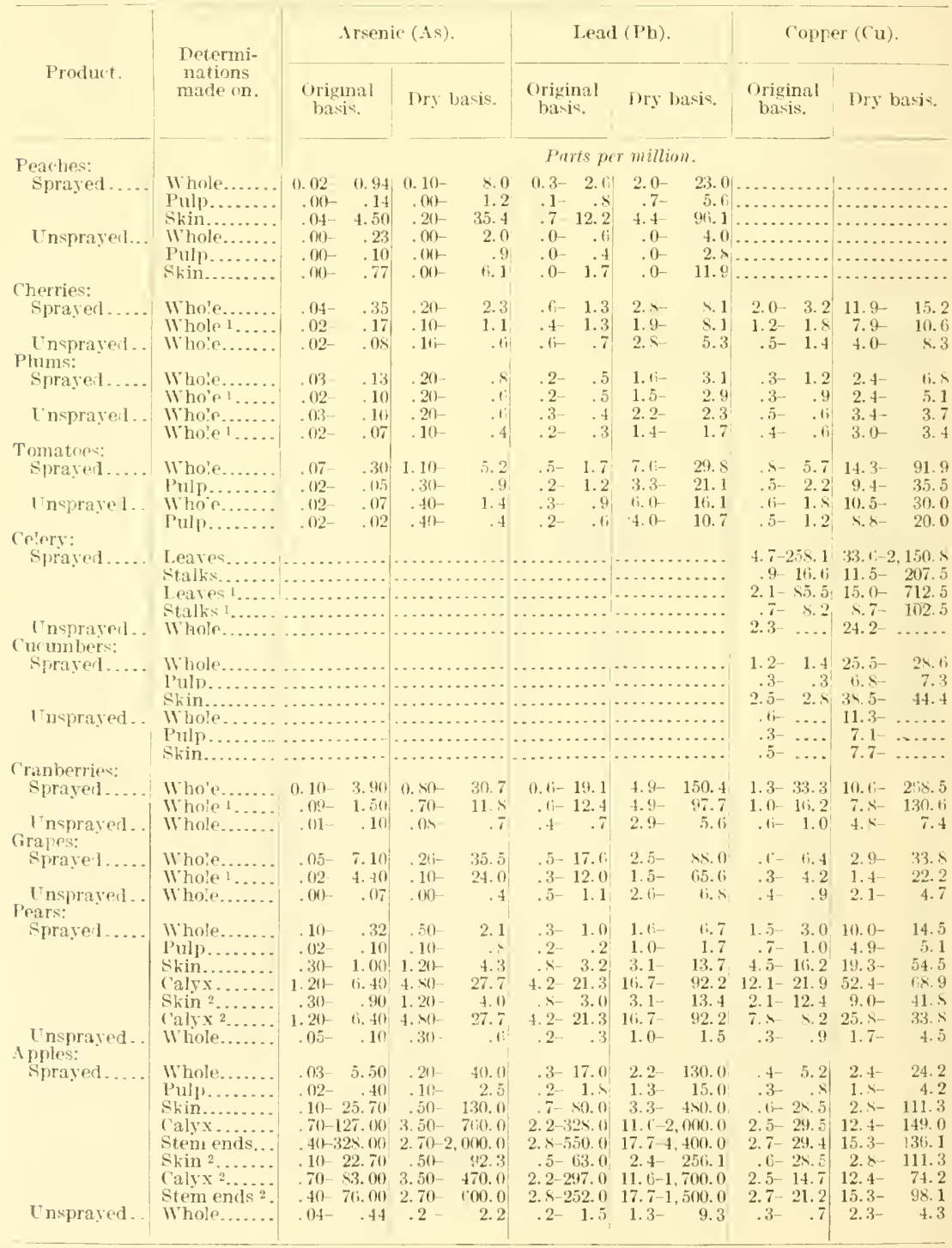


TABLE 15.-Arsenic, lead, and copper remaining on fruits and vegetables sprayed with poisonous sprays (summary)-Continued.

\begin{tabular}{|c|c|c|c|c|c|c|c|}
\hline \multirow{3}{*}{$\begin{array}{c}\text { Product. } \\
\text { Pezches: } \\
\text { Sprayed.. }\end{array}$} & \multirow{3}{*}{$\begin{array}{c}\begin{array}{c}\text { vetermi- } \\
\text { nation } \\
\text { made on. }\end{array} \\
\text { Who'e.. }\end{array}$} & \multicolumn{2}{|c|}{ Arsenic in each fruit. } & \multicolumn{2}{|c|}{ Lead in each fruit. } & \multicolumn{2}{|c|}{ Copper in each fruit. } \\
\hline & & Mg. & Grains. & $1 / \mathrm{g}$ & Grains. & Ifg. & Grains. \\
\hline & & $0.002-0.115$ & $0.000031-0.00180$ & $0.024-0.297$ & $0.00037-0.00460$ & & \\
\hline & Prilp.... & $.000-.014$ & $.000000-.00022$ & $.007-.0522$ & $.00011-.00095$ & & \\
\hline & Skin .... & $.001-.101$ & $.000015-.00160$ & $.013-.284$ & $.00020-.00446$ & & \\
\hline Unsp ayed. & Who:e... & $.000-.026$ & $.000000-.00040$ & $.000-.057$ & $.00000-.00058$ & & $\ldots$ \\
\hline & Pulp.... & $.000-.009$ & $.000000-.00014$ & $.000-.032$ & $.00000-.00049$ & & \\
\hline Pears: & Skin..... & $.000-.017$ & $.000000-.0002 i$ & $.000-.033$ & $.00000-.00051$ & & \\
\hline Sprayed.. & Who'c... & $.013-.049$ & $.000200-.00075$ & $.039-.151$ & $.00000-.00230$ & $0.227-0.411$ & $0.003500-0.00630$ \\
\hline & Pulp.... & $.003-.010$ & $.000046-.00015$ & $.015-.029$ & $.000230-.00045$ & $.095-.120$ & $.001500-.001 \times 0$ \\
\hline & Skin. & $.005-.023$ & $.000077-.00035$ & $.012-.073$ & $.030180-.00110$ & $.102-.261$ & $.001600-.00400$ \\
\hline & ('alyx. & $.002-.016$ & $.000031-.00025$ & $.005-.053$ & $.000077-.00082$ & $.030-.030$ & $.000460-.00046$ \\
\hline & Skin $2 . .$. & $.005-.014$ & $.000077-.00022$ & $.012-.054$ & $.0001 \mathrm{~S} 0-.00083$ & $.049-.200$ & $.000750-.00310$ \\
\hline & Calyx ${ }^{2}$. & $.002-.016$ & $.000031-.00025$ & $.005-.053$ & $.000077-.00052$ & $.011-.020$ & $.000170-.00031$ \\
\hline $\begin{array}{l}\text { Unsorised. } \\
\text { Apples: }\end{array}$ & Who'e... & $.006-.013$ & $.000092-.00020$ & $.022-.037$ & $.000310-.00057$ & $.033-.113$ & $.000510-.00170$ \\
\hline Sprayed.. & Who:e... & $.004-.900$ & $.000062-.01400$ & $.035-2.800$ & $.000550-.04300$ & $.054-.380$ & $.000 \times 30-.00590$ \\
\hline & Pulp... & $.002-.042$ & $.000031-.000$ i5 & $.015-.230$ & $.000230-.00350$ & $.035-.072$ & $.000540-.00110$ \\
\hline & Skin... & $.002-.442$ & $.000031-.00580$ & $.010-1.600$ & $.000150-.02500$ & $.010-.273$ & $.000150-.00420$ \\
\hline & $\begin{array}{l}\text { Calyx... } \\
\text { ste m }\end{array}$ & $.001-.154$ & $.000015-.00240$ & $.003-.400$ & $.000046-.00 \div 20$ & $.003-.032$ & $.000046-.00049$ \\
\hline & ends. - & $.001-.310$ & $.000015-.00480$ & $.003-.7 \mathrm{cis}$ & $.000041 ;-.01200$ & $.003-.035$ & $.000046-.00054$ \\
\hline & Skin ${ }^{2} \ldots$ & $.002-.345$ & $.000031-.00530$ & $.007-.958$ & $.000110-.01500$ & $.010-.273$ & $.000150-.00420$ \\
\hline & Calyx ${ }^{2}$. & $.001-.127$ & $.000015-.00200$ & $.003-.332$ & $.000046-.00510$ & $.003-.016$ & $.000046-.00025$ \\
\hline & ends ${ }^{2}$. & $.001-.170$ & $.000015-.00260$ & $.003-.524$ & $.000046-.00810$ & $.003-.025$ & $.000046-.00039$ \\
\hline Unsprayed. & Who'e. . & $.005-.051$ & $.000077-.00079$ & $.019-.178$ & $.0000291-.00270$ & $.021-.093$ & $.000370-.00140$ \\
\hline
\end{tabular}

1 Washed.

2 Wiped.

TABLE 16.-Precipitation reports for sections where samples analyzed were harvested.

BERLIN, MD., SECTION.

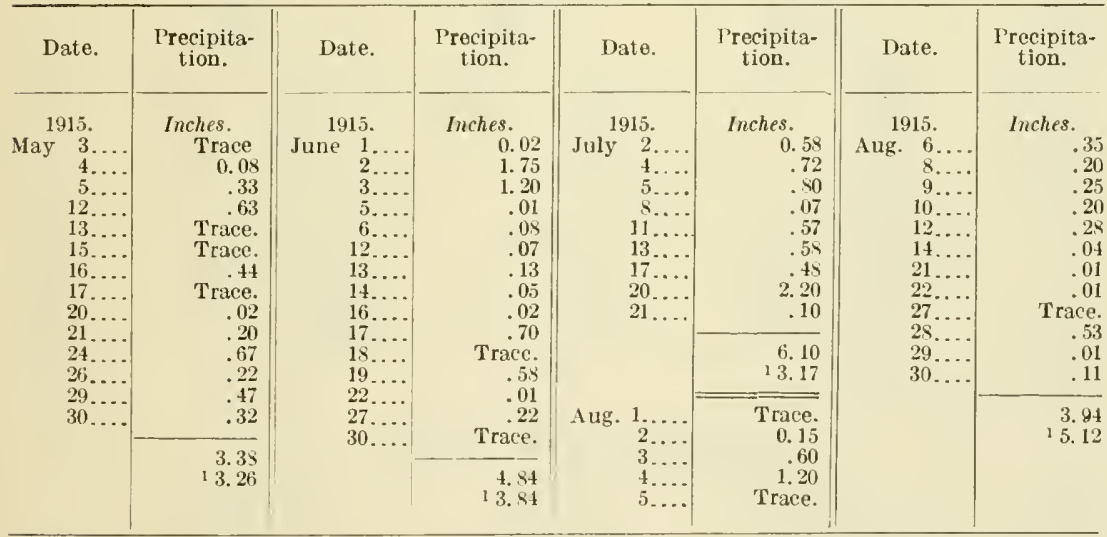

1 Normal. 
TABLE 16.-Precipitation reports for sections where samples analyzed were harvestedContinued.

SPRINGFIELD, W. VA., SFCTION.

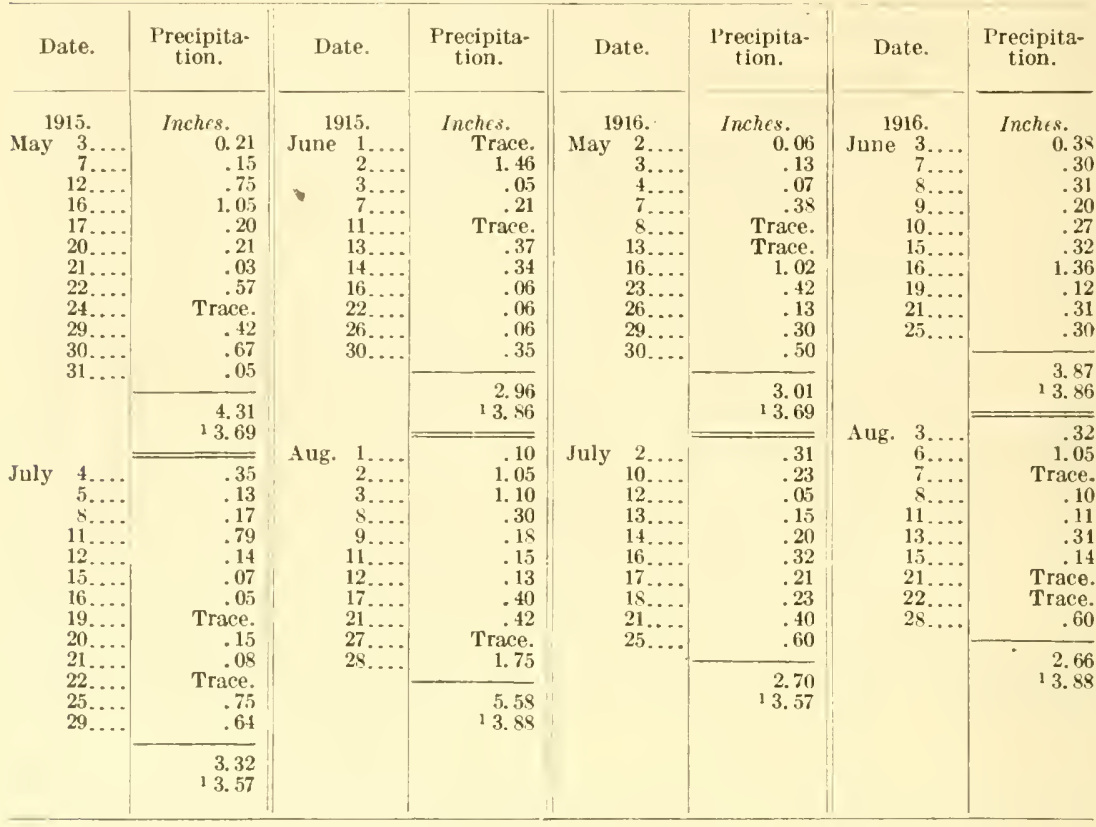

FORT VALLEY, GA., SECTION.

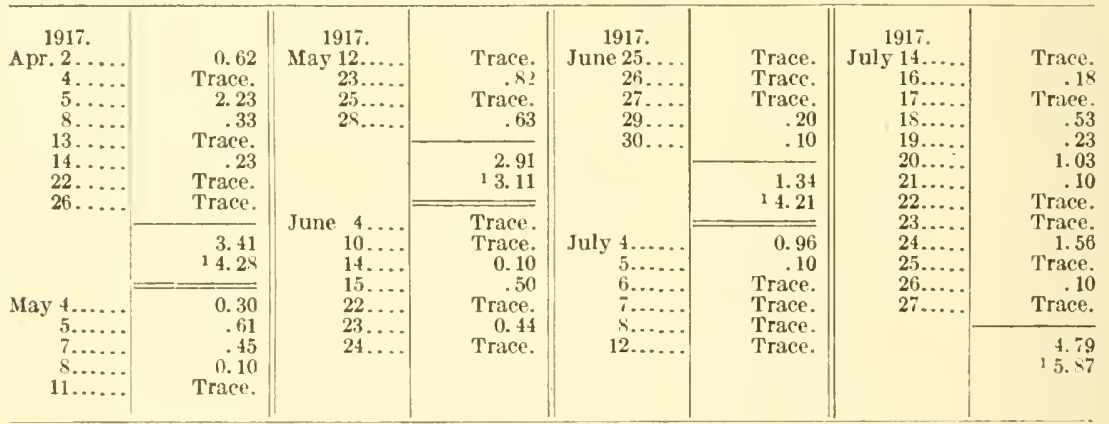

WENATCHEE, WASH., SECTION.

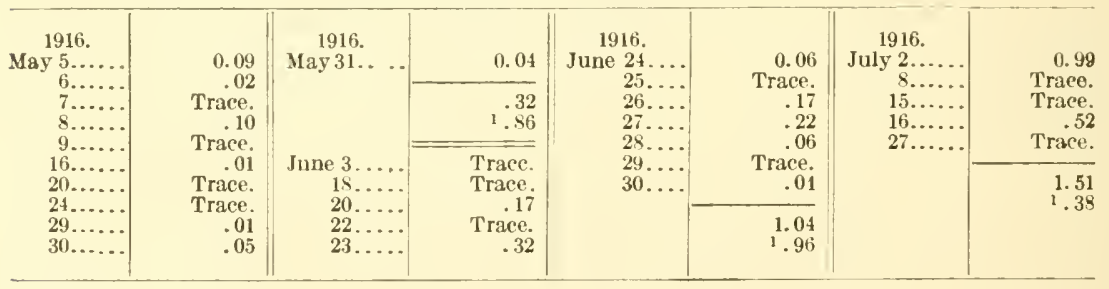

1 Normal. 
TABLE 16.-Precipitation reports for sections where samples analyzed were harvestedContinued.

HART, MICH., SECTION.

\begin{tabular}{|c|c|c|c|c|c|c|c|}
\hline Date. & $\begin{array}{l}\text { Precipita- } \\
\text { tion. }\end{array}$ & Date. & $\begin{array}{c}\text { Precipita- } \\
\text { tion. }\end{array}$ & Date. & $\begin{array}{l}\text { Precipita- } \\
\text { tion. }\end{array}$ & Date. & $\begin{array}{l}\text { Precipita- } \\
\text { tion. }\end{array}$ \\
\hline 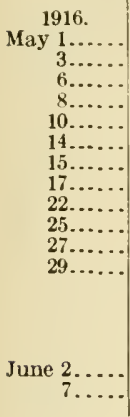 & $\begin{array}{r}\text { Inches. } \\
0.75 \\
\text { Trace. } \\
.15 \\
.27 \\
1.27 \\
.30 \\
.18 \\
.06 \\
.28 \\
.05 \\
.07 \\
.45 \\
3.83 \\
13.76 \\
\end{array}$ & $\begin{array}{r}1916 . \\
\text { June } 8 \ldots . . \\
9 \ldots \\
14 \ldots \ldots \\
17 \ldots \ldots \\
18 \ldots \ldots \\
23 \ldots \ldots \\
26 \ldots \ldots \\
30 \ldots \ldots \\
\end{array}$ & $\begin{array}{r}\text { Inches. } \\
0.72 \\
.28 \\
.95 \\
.45 \\
.04 \\
.25 \\
\text { Trace. } \\
.97 \\
4.94 \\
12.39 \\
\text { Trace. } \\
.15 \\
2.27 \\
.53 \\
.04 \\
.27\end{array}$ & $\begin{array}{r}\text { Aug. } 3 \ldots . \\
4 \ldots . \\
5 \ldots . \\
6 \ldots . \\
10 \ldots . \\
13 \ldots \ldots \\
26 \ldots \ldots \\
30 \ldots \ldots \\
\end{array}$ & $\begin{array}{r}3.26 \\
12.92 \\
.85 \\
.13 \\
.53 \\
.10 \\
.16 \\
.10 \\
.38 \\
.25\end{array}$ & $\begin{array}{r}1916 . \\
\text { Sept. } 7 \ldots \ldots \\
12 \ldots \ldots \\
13 \ldots \ldots \\
14 \ldots \ldots \\
15 \ldots \ldots \\
16 \ldots \ldots \\
17 \ldots \ldots \\
21 \ldots \ldots \\
22 \ldots \ldots \\
26 \ldots \ldots \\
27 \ldots \ldots \\
28 \ldots \ldots\end{array}$ & $\begin{array}{r}\text { Inches. } \\
0.65 \\
.05 \\
.14 \\
\text { Trace. } \\
.04 \\
.18 \\
.14 \\
.17 \\
.07 \\
.16 \\
.40 \\
.14 \\
3.11 \\
13.00\end{array}$ \\
\hline
\end{tabular}

CAMDEN, N. J., SECTION.

\begin{tabular}{|c|c|c|c|c|c|c|c|}
\hline 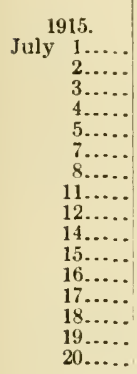 & $\begin{array}{r}0.19 \\
.53 \\
\text { Trace. } \\
.08 \\
\text { Trace. } \\
\text { Trace. } \\
.67 \\
\text { Trace. } \\
.64 \\
.35 \\
\text { Trace. } \\
.27 \\
.15 \\
\text { Trace. } \\
.25 \\
\text { Trace. }\end{array}$ & $\begin{array}{c}1915 . \\
\text { July } 21 \ldots \ldots \\
23 \ldots \ldots \\
26 \ldots . \\
27 \ldots \ldots \\
29 \ldots \ldots \\
30 \ldots \ldots \\
\end{array}$ & $\begin{array}{r}0.20 \\
\text { Trace. } \\
\text { Trace. } \\
.28 \\
1.00 \\
.01 \\
4.62 \\
4.30 \\
.13 \\
.02 \\
.32 \\
2.10 \\
\text { Trace. } \\
.31\end{array}$ & 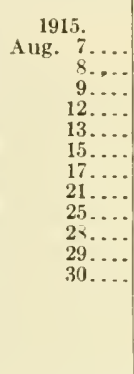 & $\begin{array}{r}\text { Trace. } \\
1.05 \\
.20 \\
.53 \\
.01 \\
.05 \\
\text { Trace. } \\
\text { Trace. } \\
.07 \\
.03 \\
1.05 \\
.74 \\
6.61 \\
14.59\end{array}$ & 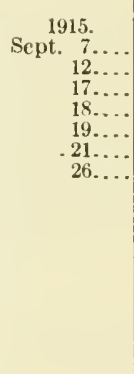 & $\begin{array}{r}\text { Trace. } \\
0.08 \\
.29 \\
\text { Trace- } \\
.09 \\
.40 \\
\text { Trace. } \\
136 \\
3.74\end{array}$ \\
\hline
\end{tabular}

\section{ARLINGTON, VA., SECTION.}

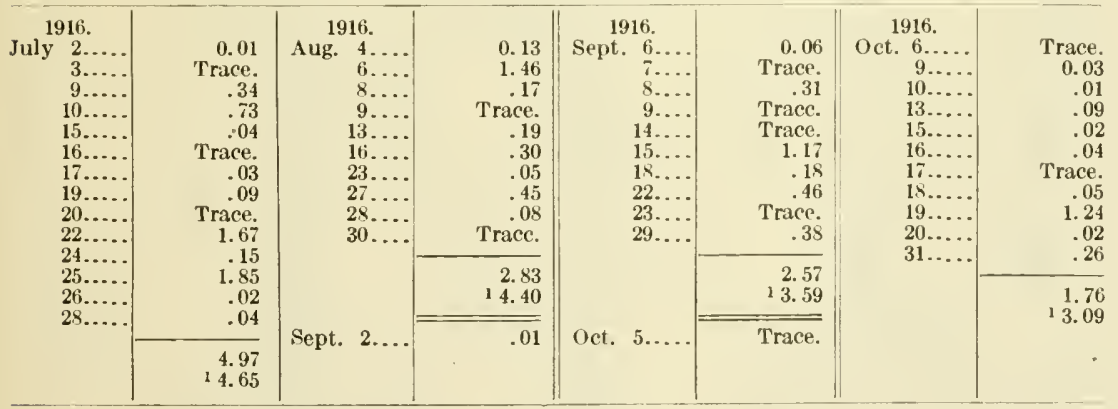

SALEM, N. J., SECTION.

\begin{tabular}{|c|c|c|c|c|c|c|c|}
\hline \multirow{3}{*}{$\begin{array}{r}1916 . \\
\text { July } 10 \ldots \ldots \\
13 \ldots \ldots \\
20 \ldots \ldots \\
21 \ldots \ldots \\
22 \ldots \ldots \\
23 \ldots \ldots \\
25 \ldots \ldots \\
26 \ldots \ldots\end{array}$} & $\begin{array}{r}1.60 \\
.34\end{array}$ & \multirow{3}{*}{ 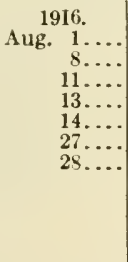 } & $\begin{array}{r}0.05 \\
.30\end{array}$ & \begin{aligned} & \multicolumn{1}{c}{1916.} \\
& Sept. $2 \ldots \\
& .6 \ldots\end{aligned}$ & \multirow{3}{*}{$\begin{array}{r}\text { Trace. } \\
0.20 \\
.22 \\
.37 \\
.32\end{array}$} & \multirow[t]{3}{*}{$\begin{array}{c}1916 . \\
\text { Sept. } 19 . \ldots \\
29 . \ldots\end{array}$} & $\begin{array}{r}0.20 \\
.52\end{array}$ \\
\hline & $\begin{array}{r}.48 \\
.02 \\
1.80 \\
.05 \\
.90 \\
.05\end{array}$ & & $\begin{array}{r}.18 \\
\text { Trace. } \\
.08 \\
.42 \\
.20 \\
\end{array}$ & $\begin{array}{r}8 \ldots . \\
8 \ldots \\
15 . . .\end{array}$ & & & $\begin{array}{r}1.83 \\
13.81\end{array}$ \\
\hline & $\begin{array}{r}5.24 \\
14.43\end{array}$ & & 14.74 & & & & \\
\hline
\end{tabular}

1 Normal. 
TABLE 16.-Precipitation reports for sections where samples analyzed were harvestedContinued.

NORTH LABERTY, IND., SECTION.

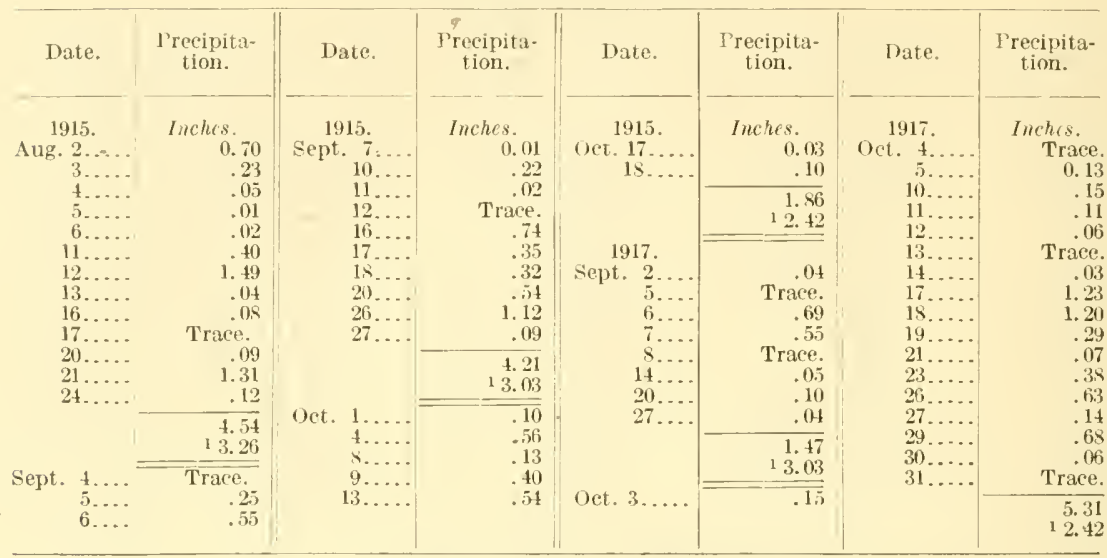

PLYMOUTH, IND., SECTION.

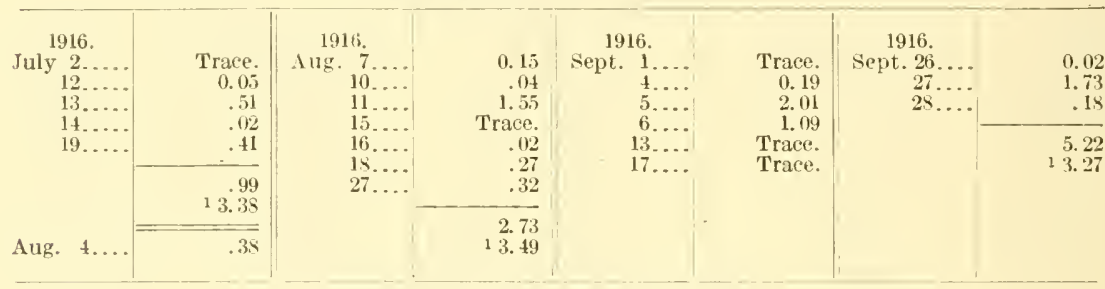

E.ST WAREHAM, MASS., SECTION.

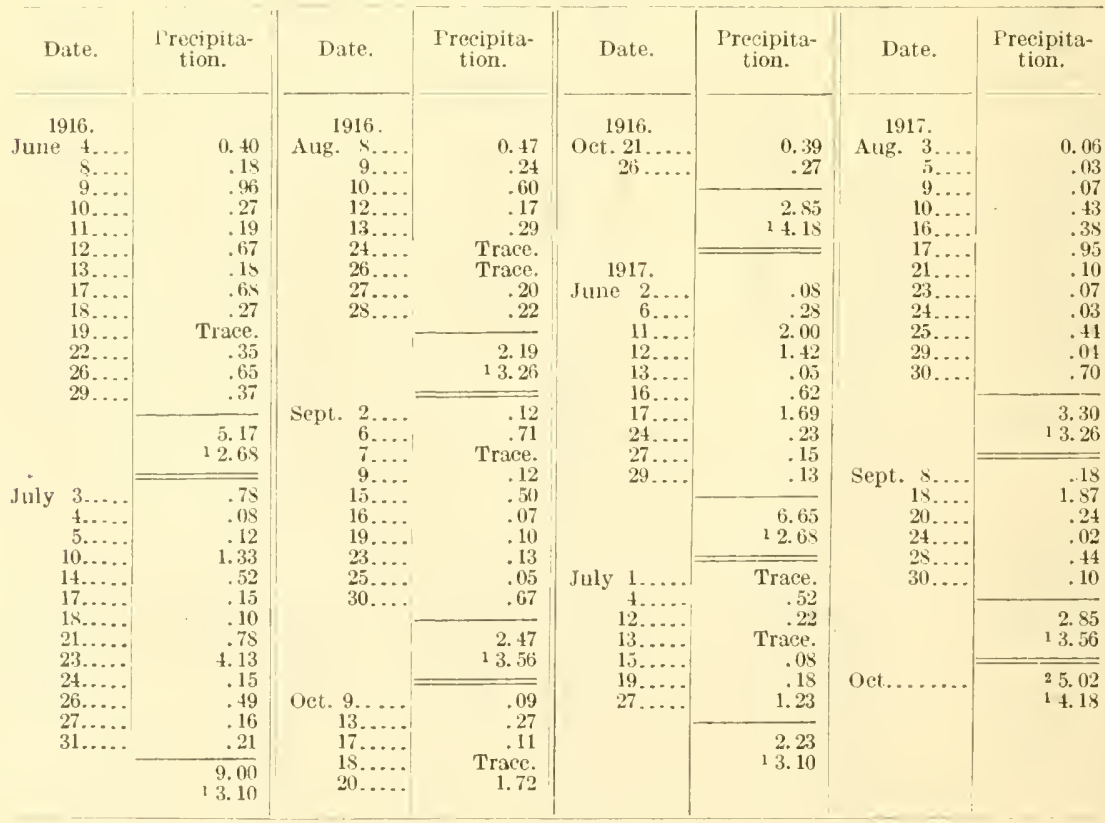


TABLE 16.-Precipitation reports for sections wher samples analyzed were harvestedContinuerl.

NORTII E.ST, P., SECTION.

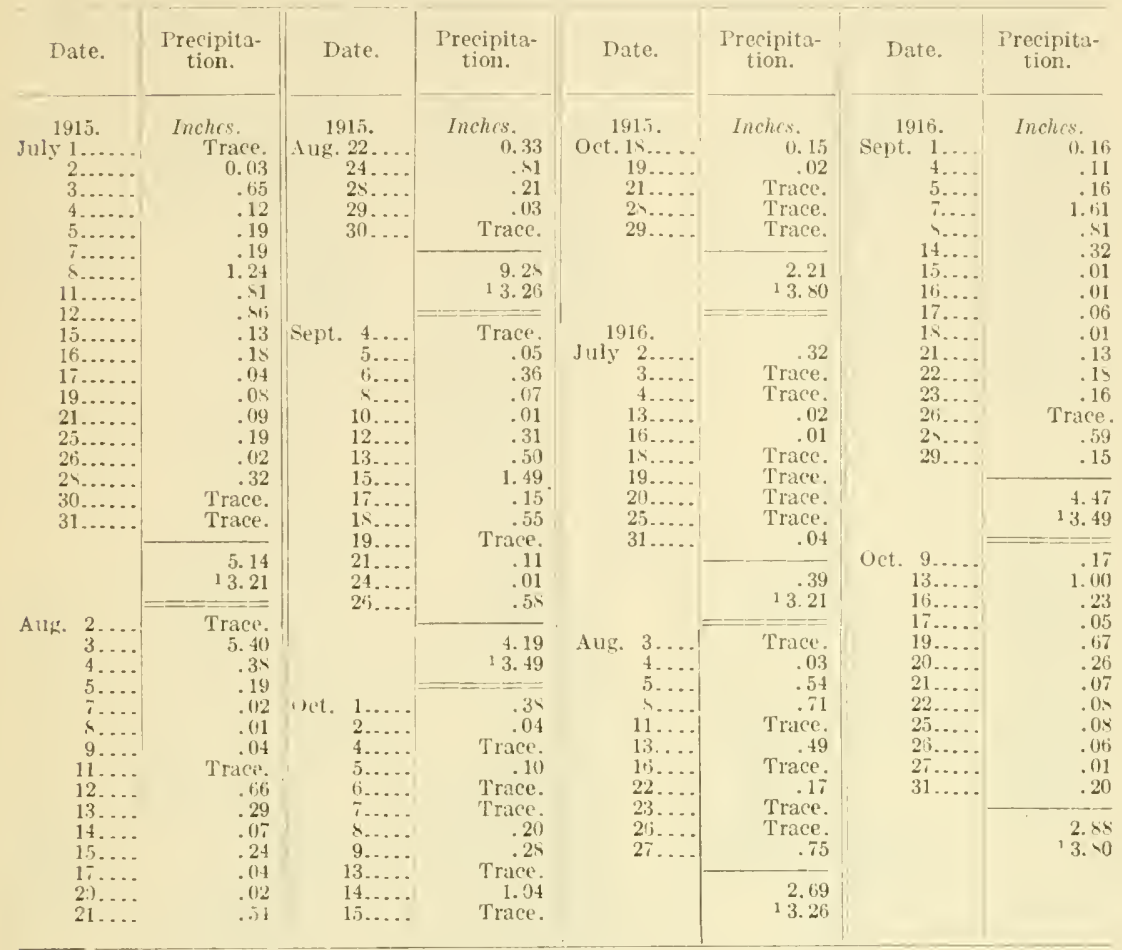

SANDUSKY, OHIO, SECTION.

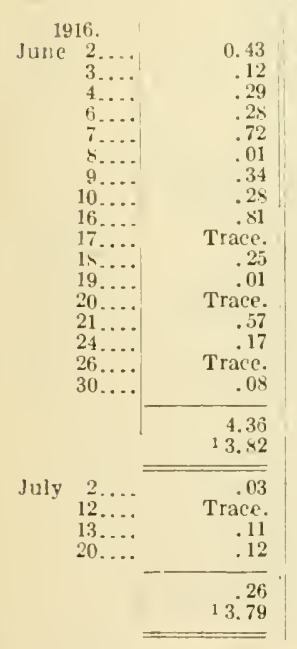

1916.

3....

$3 \ldots$
$4 \ldots$

s....

$11 . .$.

$16 \ldots$

$19 \ldots$.

$27 . .$.

(

Trace.

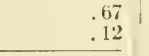

sept. $2 \ldots$

$2 \ldots$
$4 \ldots$
$5 \ldots$
7

$7 . .$.

$8 .$.

$17 . .$.

$21 . .$.

$22 .$.

$23 . .$.

$27 \ldots$

13.37

\begin{tabular}{|r}
\hline \hline Trace \\
Trace. \\
Trace \\
.63 \\
.12 \\
.05 \\
Trace. \\
.01 \\
.03 \\
Trace. \\
.20 \\
.09 \\
.90 \\
\hline 2.03 \\
12.68 \\
\hline
\end{tabular}


TABLE 16.-Precipitation reports for sections where samples analyzed were harvested.Continued.

SANDUSKY, OHIO, SECTION-Continued.

\begin{tabular}{|c|c|c|c|c|c|c|c|}
\hline Date. & $\begin{array}{l}\text { Precipita- } \\
\text { tion. }\end{array}$ & Date. & $\begin{array}{l}\text { Precipita- } \\
\text { tion. }\end{array}$ & Date. & $\begin{array}{l}\text { Precipita- } \\
\text { tion. }\end{array}$ & Date. & $\begin{array}{l}\text { Precipita- } \\
\text { tion. }\end{array}$ \\
\hline \multirow{4}{*}{$\begin{array}{r}1917 . \\
\text { Aug. } \\
9 \ldots \\
13 \ldots \\
16 \ldots \\
20 \ldots \\
21 \ldots \\
22 \ldots \\
23 \ldots \\
25 \ldots \\
27 \ldots \\
25 \ldots \\
29 \ldots \\
30 \ldots\end{array}$} & $\begin{array}{r}\text { Inches. } \\
0.07 \\
\text { Trace. } \\
.54 \\
.38 \\
\text { Trace. } \\
01\end{array}$ & \multirow{4}{*}{$\begin{array}{r}1917 . \\
\text { Sept. } 2 . \\
5 . \\
6 . \\
7 . \\
20 . \\
27 \\
29 . \\
30 .\end{array}$} & \multirow{4}{*}{$\begin{array}{r}\text { Inches. } \\
\text { (1.02 } \\
.03 \\
.73 \\
.23 \\
\text { Trace. } \\
1.31 \\
.02 \\
\text { Trace. } \\
2.34 \\
12.65\end{array}$} & \multirow{4}{*}{ 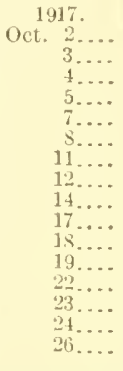 } & \multirow{4}{*}{$\begin{array}{r}\text { Inches. } \\
0.03 \\
.67 \\
.08 \\
.05 \\
\text { Trace. } \\
\text { Trace. } \\
.02 \\
.72 \\
\text { Trace. } \\
\text { Trace. } \\
.63 \\
.85 \\
.04 \\
.54 \\
\text { Trace. } \\
.18\end{array}$} & \multirow[t]{4}{*}{ 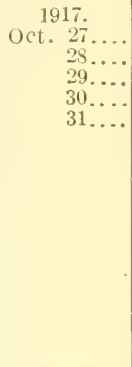 } & $\begin{array}{r}\text { Inches. } \\
.24 \\
0.44 \\
1.19 \\
.04 \\
.03\end{array}$ \\
\hline & $\begin{array}{r}.03 \\
1.79 \\
\text { Trace. }\end{array}$ & & & & & & $\begin{array}{r}6.22 \\
12.43\end{array}$ \\
\hline & $\begin{array}{r}\text { Trace. } \\
.50 \\
.30 \\
.01 \\
\end{array}$ & & & & & & \\
\hline & $\begin{array}{r}3.99 \\
13.37\end{array}$ & & & & & & \\
\hline
\end{tabular}

MOORESTOWN AND BROWN MILLS, N. J., SECTIONS.

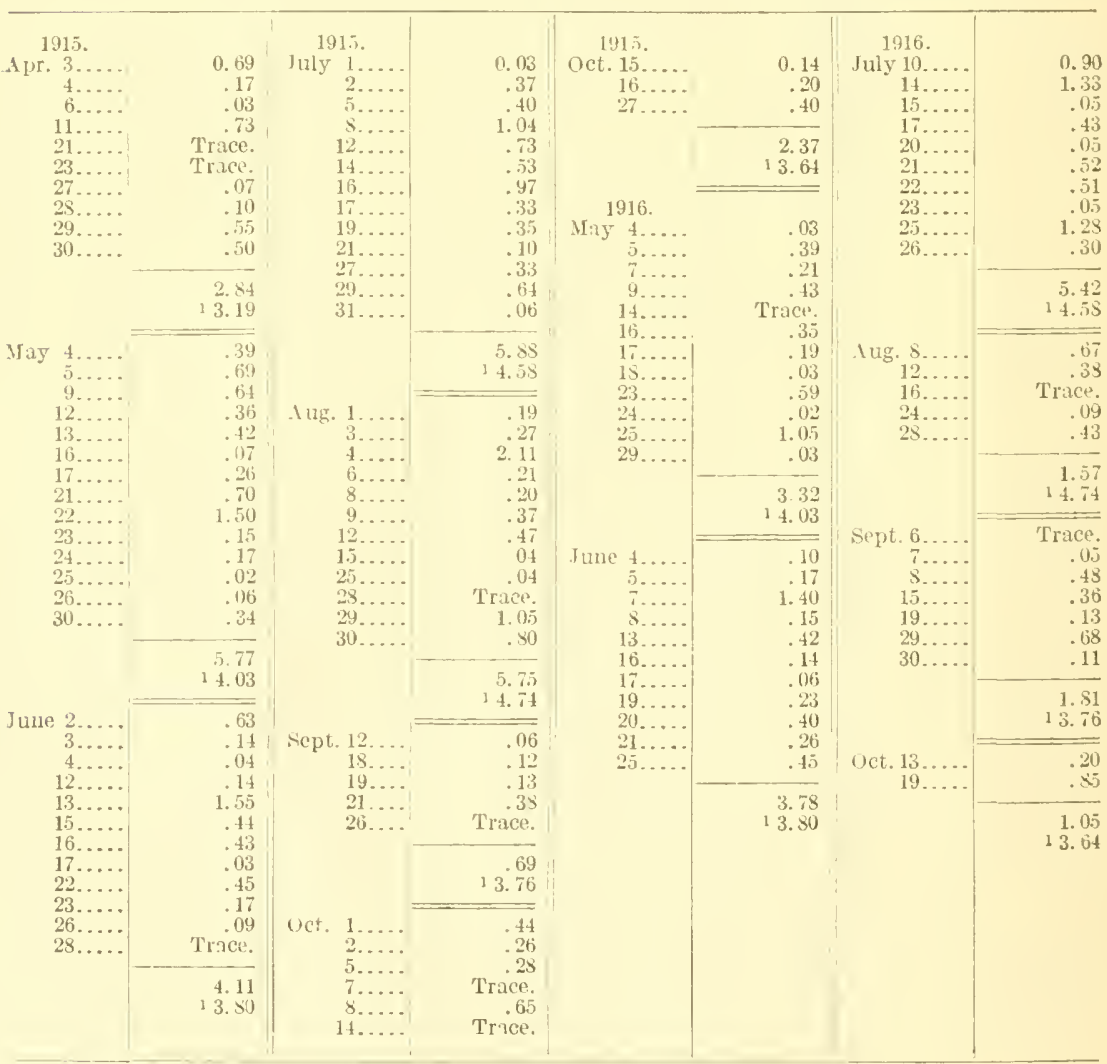

1 Normal. 
TABLE 16.-Precipitation reports for sections where samples analyzed were harvestedContinued.

ROSEWELL, N. HEX., SECTION.

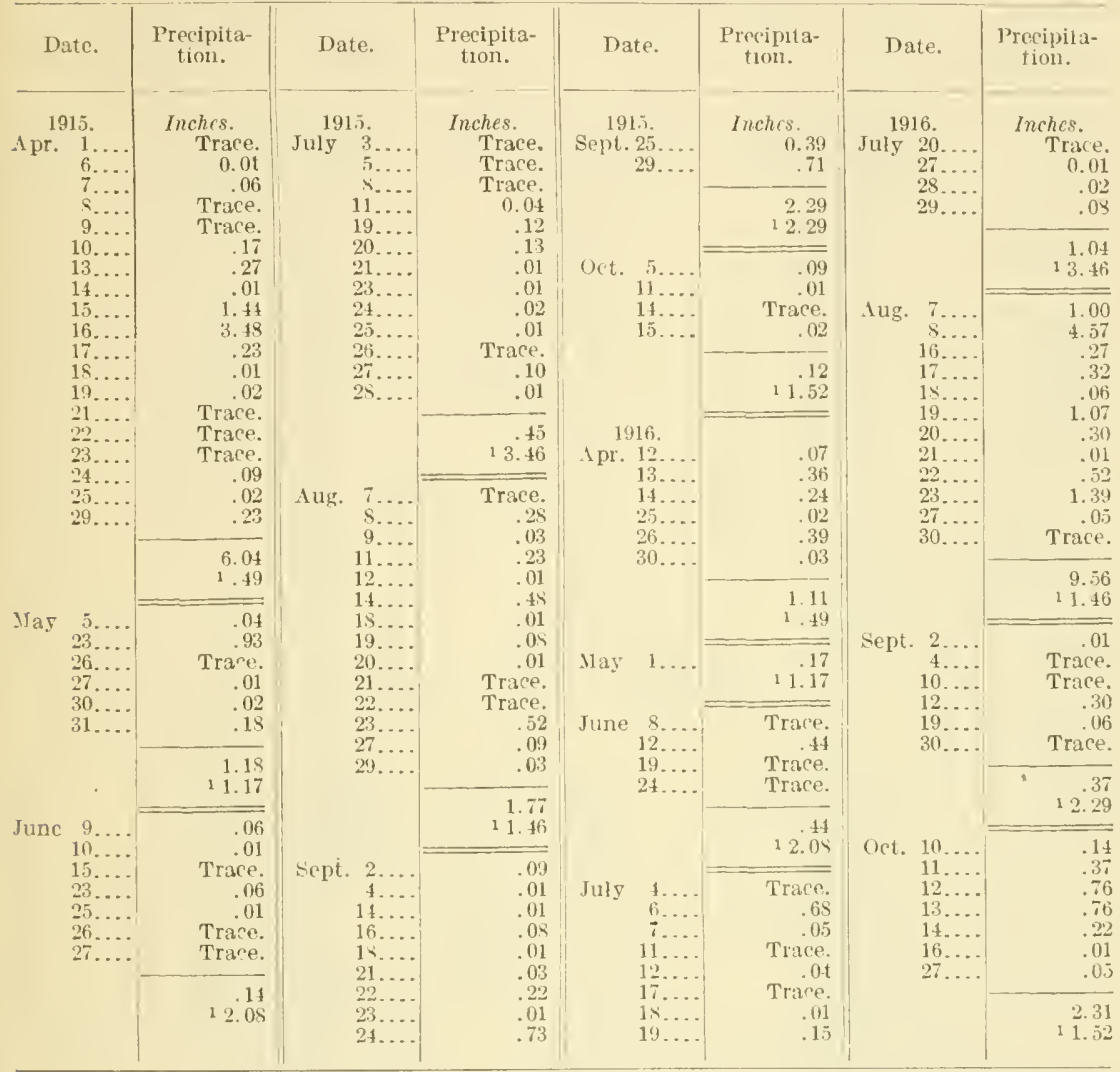

BENTON HARBOR, MICH., SECTION.

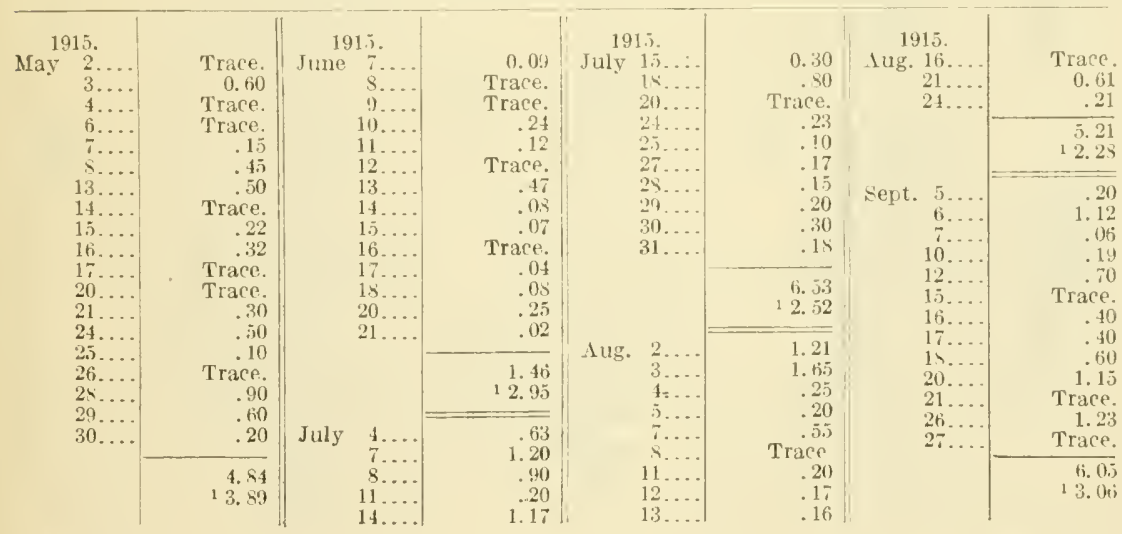

Normal. 
TABLE 16.-I'recipitation reports jor sections where samples analyzed wre harvestedContinued.

BENTON IIARBOR, MICH., SECTION-C'ontinuerl.

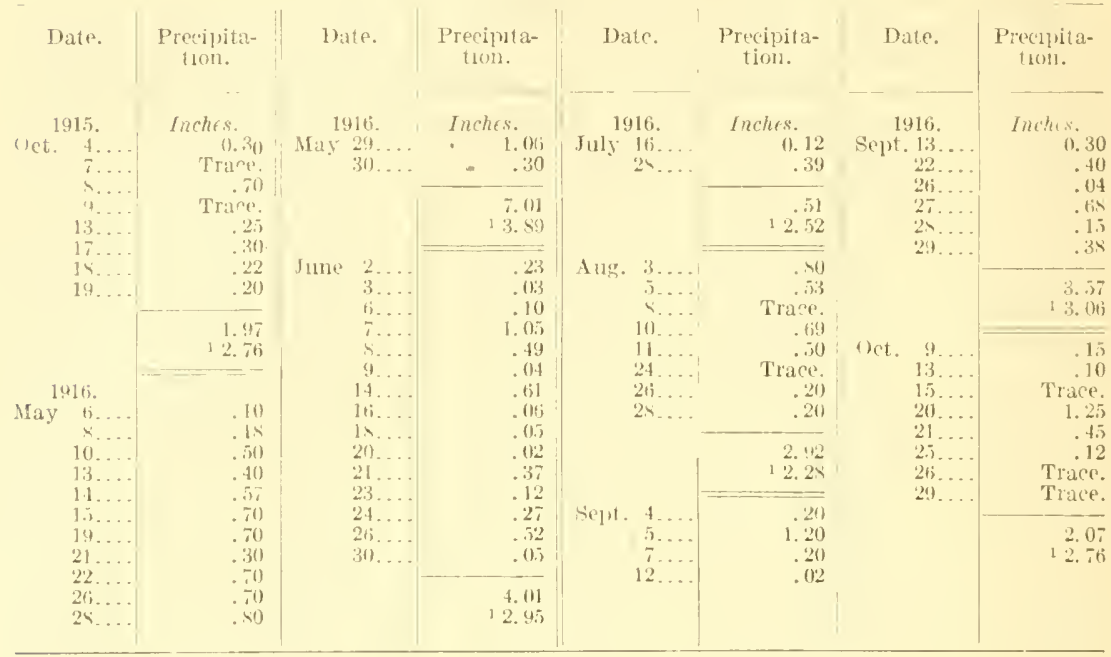

(iRANT) JYACTION, COLU), SE(TION.

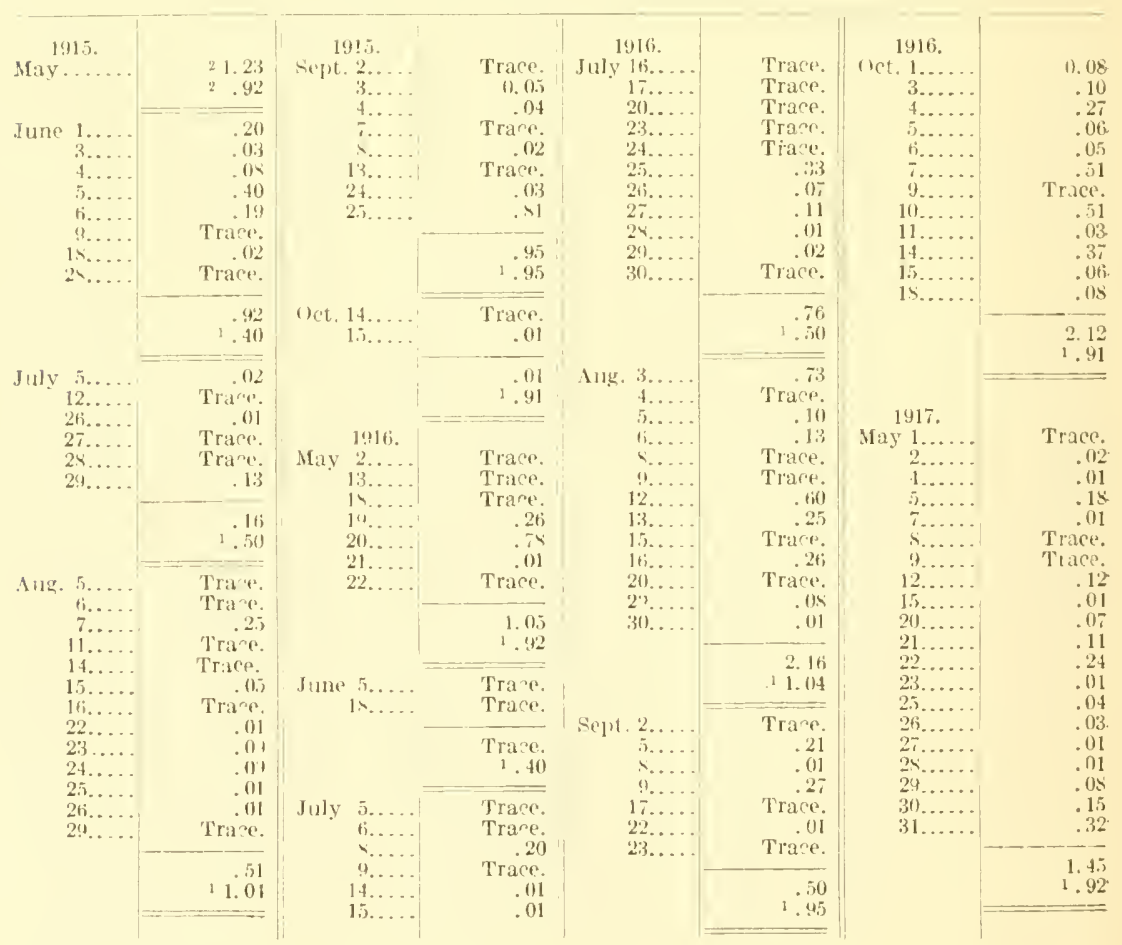

1 Normal. 
TABLE 16.-Preciyritation reports for sections where samples analyzed were harvestedcontinued.

(IR.IND JUNCTION, COLO., SECTION-Continued.

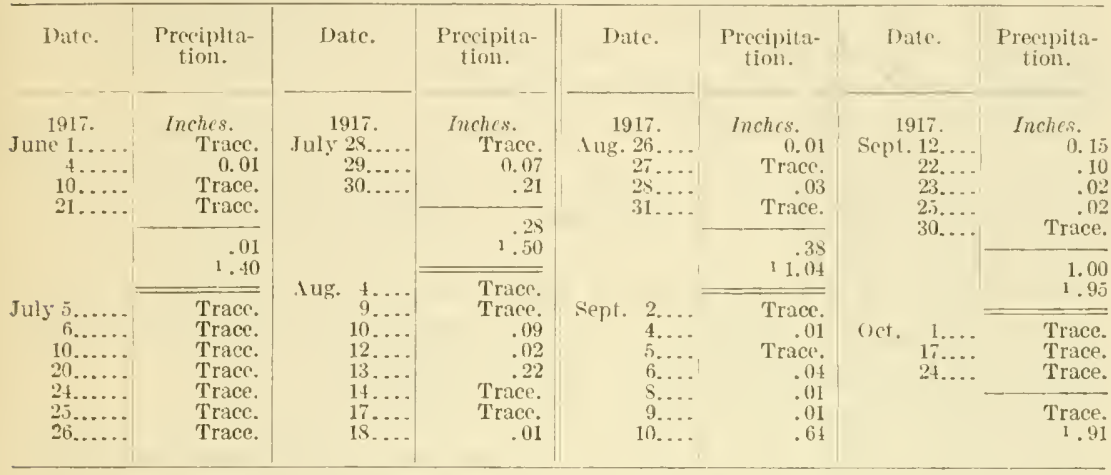

GREENWOOD, VA., SECTION.

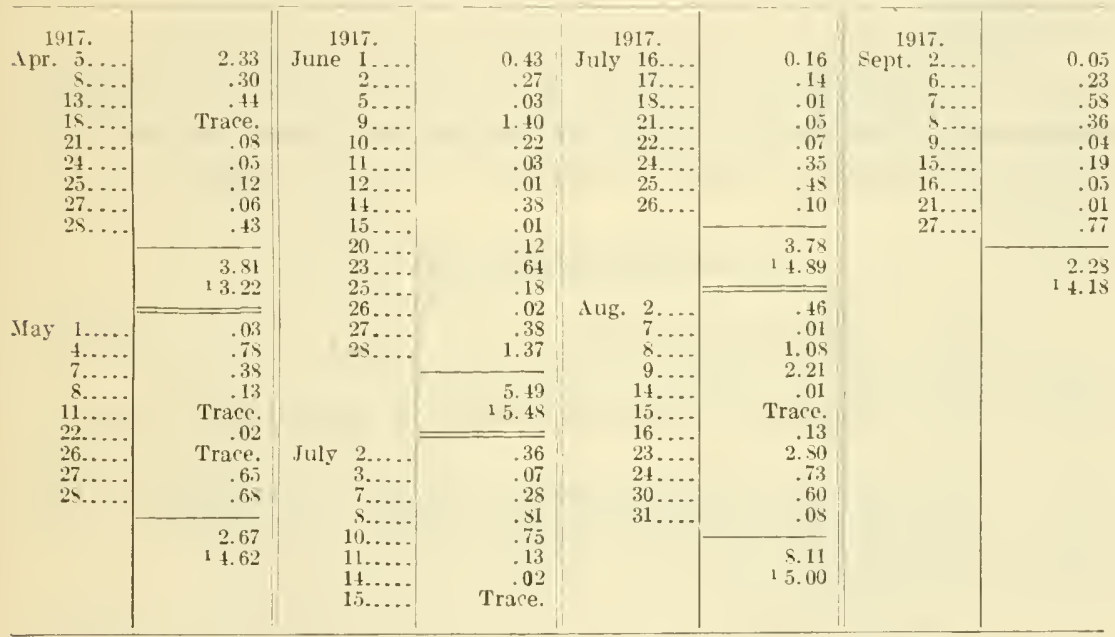

YAKIMA, WASH., SECTIOND.

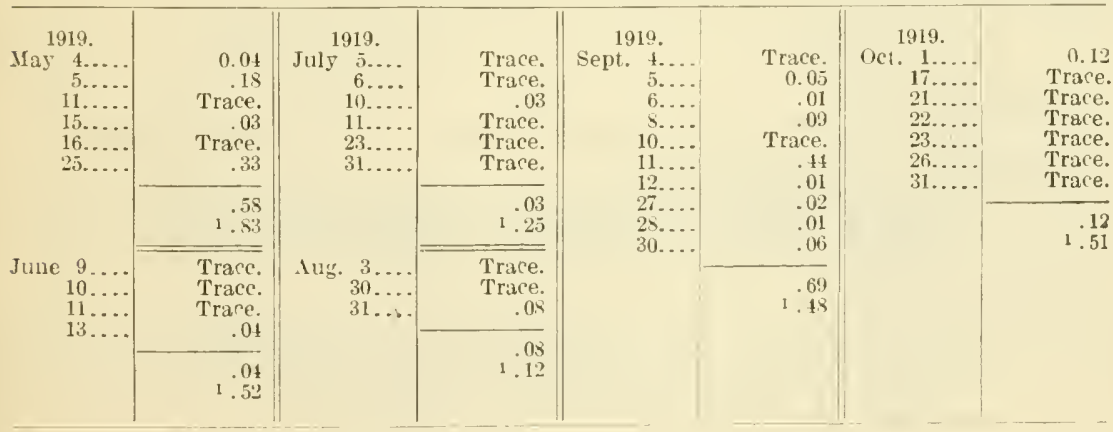

1 Normal. 


\section{SUMMARY.}

The amounts of arsenic, lead, and copper remaining on mature fruits and vegetables which have been sprayed according to various schedules were determined in the Bureau of Chemistry. Table 15 gives the maximum and minimum results.

Because of overspraying or late spraying, comparatively large quantities of spray residues were found in some cases. This emphasizes the importance of spraying according to the schedules recommended by the Bureaus of Entomology and Plant Industry.

The extent of the reduction of spray residues on the mature fruit and vegetables by washing and wiping them was determined by a series of analyses before and after such treatment.

When peeled, sprayed fruits and vegetables contain essentially the same amounts of arsenic, lead, and copper as the unsprayed products, indicating that practically all of the spray residues can be removed by peeling.

From the results reported in this bulletin it is evident that when fruits and vegetables are sprayed in accordance with the schedules recommended by the Bureaus of Entomology and Plant Industry, but little of the material used remains on the fruit or vegetable at harrest time.

\section{LITERATURE CITED.}

(1) Academy of Medicine (France).

Proc. Acad. Med.. Feb. 18, 1908. Bull. acad. med., 3 ser., 59 (1908): 246.

$(2)$

Proc. Acad. Med., Feb. 2, 1909. Bull. acad. med., 3 ser., 61 (1909): 194. (3)

Sur un projet de lécret portant modification de l'ordonnance de 1846 relative à la rente des substances vénéneuses. Bull. acad. med., 3 ser., 70 (1913): 152 .

1)

Proc. Acarl. Med., Nov. 11, 1913. Bull. acad. med., 3 ser., 70 1913): $365,369$.

5)

Proc. Acad. Med., Nar. 3, 1914. Bull, acad. med.. 3 ser., 71 (1914): $324,325,326$.

(6) Alwoon, W. B.

Treatment of diseases of the grape. Va. Agr. Exp. Sta. Bull. 15 (1892): 41.

(7) Ampola, G., and Tommasi, G.

I composti di arsenico in agricoltura. Ann. staz, chim. agrar. sper. Roma, 2 ser., 5 (1911): 241; .J. Soc. Chem. Ind., 31 (1912): 891; Chem. Alsst., 7 (1913): 1255; Exp. Sta. Rec., 30 (1914): 130.

(8) Andouard, A.

Le cuivre dans les rins provenant de vignes traitées par le sulfate de cuivre. Compt. rend., 104 (1887): 195; Bull. soc. nat. agr. (France), 47 (1887): 40; J. pharm. chim., 5 ser.. 15 (1887): 290. 
(9) Anonymous.

Spraying fruitsฐfor insect pests and fungous diseases. U. S. Dept. Agr., Farmers' Bull. 7 (1892): 17-20.

(10)

Fruit spraying. J. Roy. Hort. Soc., 18 (1895): 185.

(11) BAKER, J. L.

A résumé of the report minutes of evidence and appendices of the Royal Commission on Arsenical Poisoning. J. Soc. Chem. Ind., 23 (1904): 168.

(12) BEACH, S. A.

Some celery diseases. N. Y. Agr. Exp. Sta. Bull. 51, n. ser. (1893): 146; Exp. Sta. Rec., 4 (1892-93): 926.

(13) Bedini, R.

I sali arsenicali in frutticultura. L'istria agricola, $3 \mathrm{gr} .(1910): 538$.

(14) Bertin-Sans, H., and Ros, V.

L'emploi de l'arsenic en agriculture ses dangers. Rev. hyg. pol. sanit., 29 yr. (1907): 193.

(15)

À propos de l'utilisation des composés arsenicaux en agriculture. Rev. hyg. pol. sanit., 30 yr. (1908): 281; Exp. Sta. Rec., 20 (1908-09): 459.

(16) Bouffard, M.

La présence du cuivre métallique dans les vins provenant des vignes traitées au sulfate de cuivre. Bull. ministère agr. S (1857): 832.

(17) Breteau, P.

Sur la teneur en arsenic des vins provenant de vignes traitées par les composés de l'arsenic. J. pharm. chim., 6 ser., 28 (1908): 154; Chem. Abst., 2 (1908): 3257.

(18) Brioux and Griffon.

Les traitements arsenicaux en arboriculture fruitière. Bull. soc. nat. agr.

(19) Carles, P. (France), 70 (1910): 864 .

A propos du cuivre dans les tomates. Répert. pharm., 3 ser., 28 (1917): 193; Rev. sci., 55 yr. (1917): 183; Chem. Abst., 12 (1918): 192; Exp. Sta. Rec., 37 (1917): 263.

(20) - and BARTHE, L.

Recherche de l'arsenic de plomb dans des vins, des lies et des pépins provenant de vignes traitées à l'arséniate de plomb. Bull. soc. chim., 4 ser., 11 (1912): 413; Chem. Abst., 6 (1912): 1805; Exp. Sta. Rec., 27 (1912): 243.

(21) Cazeneuve, P.

Sur les dangers'de l'emploi des insecticides à base arsenicale en agriculture au point de vue de l'hygiène publique. Bull acad. med., 3 ser., 59 (1908): 133, 234.

$(22)$

Proc. Acad. Med., Nov. 18, 1913. Bull. acad. med., 3 ser., 70 (1913): 415.

(23) Chuard, E.

Observations concernant le mécanisme de l'introduction et de l'élimination du cuivre dans les vins provenant de vignes traitées par les combinaisons cuivriques. Compt. rend., 105 (1887): 1196.

(24)

Présence et l'élimination de l'arsenic des vins. Trav. chim. alim. hyg. bur. sanit. fed., 1, (1910): 82 . 
(25) Comboni, E.

Chemische Untersuchungen über die Weine aus Trauben, die mit kupferhaltigen Schutzmitteln gegen die Peronospora behandelt worden waren. Nuova Rassegna Vitic., 2: 209; thromgh Chem. Centr., 3 ser., 19 yr. (1888): 875 .

(26) COOK. А. ..

Two new uses of important insecticides. Proc. 29 Meeting Am. Assoc. Adv. Sci. (1880): 669 .

Experiments with insecticides. Proc. 2 Ann. Meeting Soc. Prom. Agr. Sici. (1881) : 112.

(28) Crolas and Raulin.

Traitement de la vigne par les sels de cuivre contre le mildew. Compt. rend., 103 (1886) : 1068; J. pharm. chin., 5 ser., 15 (1887) : 156.

(29) Cugini, G.

Ueher die Bekämpfung der Peronospora Viticula und den Einfluss der Mittel auf die Zusammensetzung des Mostes und Weines. Nat. Bot. Kongr. Parma, 1 (1887): 5; through (hem. Centr., 3 ser., 19 yr. (1888) : 532.

(30) Davis, G. C.

Celery iusects. Mfich. Agr. Exp. Sta. Bull. $102(1893): 44$.

(31) Duclaux, E.

Sur le dosage de très petites quantités de cuivre et la présence de ce méta! dans les cacaos et chocolats. Bull. soc. chim. 16 (1871) : 33.

(32) Duguet et al.

Proc. Acad. Med., June 28, 1910. Pull. acad. med., 3 ser., 63 (1910) :657.

Proc. Acad. Med., Mar. 7, 1911. Bull. acad. med., 3 ser., 65 (1911):346.

Proc. Acad. Med., July 11, 1911. Bull. acad. med., 3 ser., 66 (1911): 59.

(35) Dupré, A.

On copper in food. Analyst, 2 (1878): 1 .

(36) Fallot, B.

Le cuivre dans les rins. Prog. agr. vit., June 16, 18s9; through U. S. Dept. Agr., Div. Bot. Bull. 11 (1890): 96.

(37) Fetel, P.

De la teneur en arsenic des raisins d'Algérie et en particulier des raisins proveuant des vigues ayant subi des traitements aux sels arsenicaux. Bull. agr. Algérie et Tunisie, 16 (1910) : 430; Exp. Sta. Rec., 25 (1911) : 40.

(38) Fletcher, J.

The results of an experiment to prove that apples are not poisoned by spraying with Paris green for codling moth. Can. Exp. Farms Rpt. for 1891, p. 189; Exp. Sta. Rec., 4 (1892-93): 437.

(39) Forbes, S. A.

Spraying apples for the plum curculio. Ill. Agr. Exp. Sta. Bull. 108 (1906) : 279; Exp. Sta. Rec. 18 (1906-7) : 160.

(40) Forbush, E. H.

On the work of extermination of the gypsy moth. Mass. Bd. Agr. 41. Ann.

(41) Fréchou. Rpt. (1993): 282.

Le black-rot et les vins des rignes traitées. J. agr. (Barral), 24 yr. (1889): 649 . 
(42) Frühauf, T., and Ursic, G.

Die Bestimmung sehr geringer Mengen Kupfer. Bol. soc. Adriatica sc. nat. Trieste, $10: 103$; through Chem. Centr., 3 ser., 19 yr. (1888) :198; Staz. sper. agrar. ital. (1888) : 704; through J. Soc. Chem. Ind., 8 (1889) : 206.

(43) Galippe.

Sur la présence du cuivre dans les céréales, la farine, le pain et diverses autre substances alimentaires. Compt. rend. soc. biol., 7 ser., 4 (1882): 726; Rev. hyg. pol. sanit., 5 yr. (1883) : 23.

(44)

Sur la présence du cuivre dans le cacao et dans le chocolat. J. pharm. chim., 5 ser., 7 (1883) : 505; Répert. pharm., n. ser., 11 (1883) : 267.

(45)

Le sulfate de cuivre et le mildew. J.pharm. chim., 5 ser., 15 (1887) : 430 .

(46) Galloway, B. T.

The grape scare in New York. U. S. Dept. Agr. Ann. Rpt. for 1891, p. 375.

(47) - - and Fairchild, D. G.

Copper on the fruit at the time of harvest. U. S. Dept. Agr., Div. Veg. Path. Jour. Mycol., 6 (1891) : 94.

(48) Garino, E.

Determination of arsenic in wine made from grapes that had been subjected to cuproarsenical treatment. Ann. accad. agr. Torino, 56 (1914): 78; Ann. chim. applicata, 3 : 148; through Chem. Abst., 9 (1915) : 1526.

(49) Garman, H.

Spraying for codling moth. Ky. Agr. Exp. Sta. Bull. 53 (1894) : 125.

$(50)$

The use of arsenites on tobacco. Ky. Agr. Exp. Sta. Bull. 53 (1894): 142.

(52) Gautier, A.

Sur l'emploi des arsenicaux en agriculture. Bull. acad. med., 3 ser., 59 (1908) : 229.

(53)

$(55)$

Proc. Acad. Med., Nov. 11, 1913. Bull. acad. meil., 3 ser., 70 (1913) : 370.

Proc. Acad. Med., Mar. 3, 1914. Bull. acad. med., 3 ser., 71 (1914) : 300.

Origines alimentaires de l'arsenic normal chez l'homme. Compt. rend., 139 (1904) : 101; Exp. Sta. Rec., 16 (1904-05) : 499.

(56) Gayon, U., and Millardet, A.

Le cuivre dans la récolte des vignes soumises à divers procédés de traitement du mildew par les composés cuivreux. Compt. rend., 103 (1886): 1240; J. pharm. chim., 5 ser., 15 (1887) : 153.

(5i) Gibis, H. D., and James, C. C.

On the occurrence of arsenic in wine. J. Am. Chem. Soc., 27 (1905) : 1484.

(58) Gillette, C. P.

Experiments with arsenites. Iowa Agr. Exp. Sta. Bull. 10 (1890):410.

$(59)$

(60) Günther, A.

Notes and experiments upon injurious insects and insecticides. Iowa Agr. Exp. Sta. Bull. 12 (1891): 536.

Ergebnisse der amtlichen Weinstatistik, Berichtsjahr 1908-1909. Arb. Kais. Gesundh., 35 (1910) :1; Exp. Sta. Rec., 24 (1911) : 267. 
(iil) Heide, C. Von Der.

Analytische Befunde von Hosten und Weinen aus Trauben der mit Bleiarseniat bespritzten Reben. Ber. Kigl. Lehranst. Wein-, Obst- u. Gartenbau, Geiseuheim (1906): 22s; ('hem. Abst., 3 (1909):2338.

(6:) Hoffmann, M.

Ein Beitrag zur Translokation des Kupfers bein Keltern gekupferter

Trauben. Centr. Bakt. Parasitenk, part 2, 4 (1898) : 369, 422.

(63) Howarb), L. ().

Progress in economic entomology. U.S. Dept. Agr. 1899 Yearlook, p. 146.

(64) Kedzie, R. C.

Influence of Paris green on the potato. Michigan Farmer, June 9.1872.

The use of poisons in agriculture. Mich. Bd. Health, 3 Ann. Rpt. 61875):11.

Mineral residues in sprayed fruits. Mich. Agr. Exp. Sta. Bull. 101 (1893): 19: Exp. Nta. Rec., 5 (1893-94): 793.

(67) Krliore, B. W.

On the cause and prevention of the injury to foliage by arsenites, together with a new and cheap arsenite, and experiments on combining arsenites with some fungicirles. N. C. Agr. Exp. Sta. Bull. 77-b (1891) : 7 .

(68) Kinney, L. F.

Leaf blight of the pear. R. I. Agr. Exp. Sta. Bull. 27 (1894); Exp. Sta. Rec., 5 (1593-94) : 986.

(69) KrÜGER, F.

Ueber den Einfluss von Kupfervitriol auf die Vergärung von Traubenmost durch Saccharomyces ellipsoideus. Centr. Bakt. Parasitenk, part 2, $1(1895): 64$.

(70) LE Baron. W.

Second annual report on the noxious insects of the State of Illinois (1872), p. 116.

(71) Lehmann, K. B.

Hygienische Studien über Kunpfer. Arch. Hyg., 24 (1895) : 18.

$(72)$

Hygienische Studien über Kupfer. Arch. Hyg., 27 (1896): 1; Analyst, 21 (1896): 290.

(73)

Hygienische Studien über Kupfer. Arch. Hyg., 30 (1897): 250.

(74) Liberi, G., Cusiano, A., Marsiglia, T., and Zay, C.

The presence of copper in tomatoes and tomato preserves. Ann. staz. chim. agrar. sper. Roma. ser. 2, 8 (1916): 163; through Bull. Agr. Intelligence, 7 yr. (1916): 662, and Chem. Abst., 11 (1917): 1701.

(75) Lodeian, E. G.

The spraying of plants $(1896)$, p. 64, 65. MacMillan \& Co., New York.

(76) LuCET, A.

Proc. Acad. Med., Mar. 3, 1914. Bull. acad. med., 3 ser., 71 (1914): $299,311$.

(77) McElroy, K. P.

Canned regetables. T.S. Dept. Agr., Div. Chem. Bull. 13, part 8 (1893).

(7S) McJlurtrie, W.

The influence of arsenical compounds, when present in the soil, upon regetation. U. S. Com. Agr. Ppt. for 1875, p. 147. 
(79) МАCH, E.

Bericht über die Ergebnisse der im Jahre 1886 ausgelïlorten Versuche zur Bekïmpfung (ler Perenospora. Tirol. Landw. B1., 6 (1587): 37, 53; through Jahr. Agr. (hem. (Hilger), n. ser, 10 (1887): 270.

(SO) $M$ ALYY, II.

J. agr. prat., 22 (1911) : 293.

(81)

Décret concernant l'importation, le commerce, la détention et l'usage des sulstances vénéneuses. Bull. intern. repr. fraudes, 9 yr. (1916) : 145.

(s.) VARÈs, R.

Les bouillies arsenicales et la lutte contre les altises. Rev, vit., 25 (1906): 426.

(S3) Mathieu, M.

Recherche de l'arsenic sur les raisins et dans les vins. Inn. fals., 5 yr. (1912): 78; Chem. Abst., 7 (1913): 204; Exp. Sta. Rec., 26 (1912): 841; J. Soc. Chem. Ind., 31 (1912): 295.

(S4) MaYNakd, S. T.

The amount of copper on sprayed fruit. Mass. Hatch Igr. Exp. Sta. Bull. 17 (1892): 38; Exp. Sta. Rec., 3 (1891-92): 865.

(85)

The amount of copper on sprayed fruit. Mass. Hatch Agr. Exp. Sta. Bull. 17 (1.892): 39; Exp. Sta. Rec., 3 (1891-92): 86 J.

(S6) MÉLINE, J.

Instruction pour la vente et l'emploi en agriculture des composés arsenicaux. Bull. intern. repr. fraudes, 9 yr. (1916): 157.

(8i) Mestrezat, W.

La question du danger de l'emploi des sels arsenicaux en agriculture. J. pharm. chim., 6 ser., 28 (1908): 393; Chem. A hist.. 3 (1909): L569; Exp. Sta. Rec., 20 (1908-09): 959.

(8\&) Millardet, A.

Ann. soc. agric. Cironde, $\Lambda$ pr. 1,1885 , p. 73 ; through The Spraying 0 Plants, by E. G. Lodeman, p. 27.

(89)

Sur l'histoire du traitement du mildiou par le sulfate de cuivre. J. agr. prat., 2 (1885): 801.

(90) - $\longrightarrow$ and Gayon, U.

Recherche du cuivre sur les vignes traitées par le mélange de chaux et de sulfate de cuivre, et dans la récolte. Compt. rend., 101 (1885) : 985; J. agr. prat., 2 (1885): 732 .

(91) Miruan, M.

Proc. Acad. Med., Feb. 2, 1909. Bull. acad. med., 3 ser., 61 (1909): 194.

(92) Moreau, L., and Vinet, E.

L'arseniate de plomb en viticulture. Compt. rend., 150 (1910) : 787; Bull. agr. Algérie et Tunisie, . 6 (1910) : 187; Exp. Sta. Rec., 24 (1.911): 168; Ann. chim. anal., 15 (1910): 346; Chem. Abst., 4 (1910): 2539.

Sur les traitements insecticides en viticulture. Compt. rend,, 151 (1910): 1068; Exp. Sta. Rec., 25 (1911): 40.

$L$ 'arseniate de plomb en viticulture et la consommation des raisins frais et des raisins sec. Compt. rend., 151 (1910): 1147; Ann. chim. anal., 16 (1911): 94; Chem. Abst., 5 (1911): 1968; Exp. Sta. Rec., 25 (1911): 40. 
(95) Moreau, L., and Vinet, E.

Comment s'élimine l'arseniate de plomb apporté par la vendange. Compt. rend., 152 (1911): 1057; Chem. Abst., 5 (1911): 2296.

(96) Moureu ét aL.

Sur l'emploi des composés arsenicaux en agriculture considéré au point de vue de l'hygiène publique. Bull. acad. med., 3 ser., 61 (1909): 17; L'engrais, 24 (1909): 211; Chem. Abst., 3 (1909): 1569.

(97) Munson, W. M.

Report of the horticulturist. Maine Agr. Exp. Sta. Ann. Ript. for 1891, p. 106.

(98) Muttelet, C. F.

L'arseniate de plomb en viticulture. Inn. fals., 9 yr. (1916): 298; Chem. Alst., 11 (1917): 684; Exp. Sta. Rec., 36 (1917): 537.

(99) Muttelet, F., and Touplain, F.

L'arseniate de plomb en viticulture. Ann. fals., 5 yr. (1912): 9; Chem. Abst., 6 (1912) : 910.

(100) Odling, W., and Dupré, A.

On the existence of copper in organic tissues. Guy's Hospital Reports. 3 ser., 4 (1858): 103.

(101) O'Gara, P. J.

Presence of arsenic in fruit sprayed with arsenate of lead. Science, n. ser., 33 (1911): 900; Chem. Abst., 6 (1912): S9S; Exp. Sta. Rec., 25 (1911): 642.

(102) O'Kane, W. C., Hadley, C. H., and Osgood, W. A.

Arsenical residues after spraying. N. H. Agr. Exp. Sta. Bull. 183 (1917); Exp. Sta. Rec., 38 (1918): 54; Chem. Abst., 11 (1917): 2836.

(103) Ormerod, Eleanor A.

Notes of the season. U. S. Dept. Agr., Div. Ent. Per. Bull., Insect Life, $4(1591-92): 36$.

(104) Papasogli, G.

Anwendung der Kupfersalze auf die Weinstöcke und hierauf bezugliche Betrachtungen. L'Orosi, 10 (1S87): 369; through Chem. Centr., 3 ser., 19 yr. (1885): 234.

(105) Penny, C. L.

Several articles of food known to be healthful found to contain small quantities of copper. Del. Agr. Exp. Sta. 2 Ann. Rpt. (1889): 172; Exp. Sta. Rec., 2 (1590-91): 324.

(106)

(107) Perrett, M.

Copper on grapes. Del. Agr. Exp. Sta. 3 Aun. lipt. (1890): 149; Exp. Sta. Rec., $3(1891-92): 690$.

Le sulfate de cuivre contre le phylloxera et le mildiou. J. agr. prat., 2 (1855): 630 .

(108) Polacci, E.

Ueber eine chemische Thatsache, welche beweist, dass Schwefelsaures Kupfer aus den Trauben nur in ganz geringen Mengen in den Wein übergehen kann, nebst kritischen Bemerkungen über einige zur Bekämpfung der Perenospera vorgeschlagene Mittel. Rendi. ist. Lombardo. 20: 413 ; through Chem. Centr., 3 ser., 18 yr. (1887): 939.

(109) Popenoe, E. A., and Mason, S. C.

Second report on the experimental vineyard. Kan. Agr. Exp. Sta. Bull. 28 (1891): 166; Exp. Sta. Rec., 3 (1S91-92): 788. 
(110) Porchet, F.

Les traitements culturaux aux sels d'arsenic et l'hygiène alimentaire. Trav. chim. alim. hyg. bur. sanit. féd., 1 (1910): 79; Schweiz. Wochschr., 48 yr. (1910): 694; Chem. Abst., 5 (1911): 754.

(111) Quantin, H.

Sur la réduction du sulfate de cuivre pendant la fermentation du vin. Compt. rend., 103 (1886): 888; J. pharm. chim., 5 ser., 15 (1887): 39.

(112) RICHE, A.

Sur les dangers de l'emploi des insecticides à hase arsenicale en agriculture. Bull. acad. med., 3 ser., 59 (1908): 192, 244.

(113) Riley, C. V.

Potato pests, p. 67. Orange Judd Co., New York (1876).

(114) Rising, W. B.

Report of the State Analyst for 1887. Ann. Rpt. Bd. Calif. State Vit. Com. for 1887, p. 133.

(115) Royal Coumission on Arsenical Poisoning.

Final Report, p. 36. Eyre and Spottiswoode, London (1903).

(116) Scribner, F. Lamson.

Fungous diseases of plants. Rpt. U. S. Com. Agr. for 1885, p. 84.

(117) Selby, A. D.

The relation of grape spraying to public health. Ohio Agr. Exp. Sta. Bull. 130 (1902): 42; Exp. Sta. Rec., 14 (1902-03): 61.

(118) Sestini, F., and Tobler, O.

Ueber das Kupfer welches Weine enthalten, die aus mit Kupfersalzen behandelten Trauben herstammen. L'Orosi, 10 (1857): 289; through Chem. Centr., 3 ser., 18 yr. (1887): 1450.

(119) Sonntag, G.

Zu der Verwendung von Arsen und Blei enthaltenden Pflanzenschutzmitteln. Arb. Kais. Gesundh., 49 (1914): 502; Chem. Centr., 86 yr. (1915): 450; Chem. Abst., 9 (1915): 1819.

(120) Spallino, R.

Sulla presenza del hario e dell' arsenico nei taluacchi lavorati italiani. Crazz. chim. ital., 43 yr., part 2 (1913): 475; Chem. Abst., 8 (1914): 787 ; Exp. Sta. Rec., 31 (1914): 715.

(121) Szaneitat, A.

Analytische Befunde von Mosten und Weinen aus Trauben der nit Arsenverbindungen bespritzten Reben. Ber. Kigl. Lehranst. Wein-, ()lst- u. Gartenbau Geisenheim (1907), p. 176; Exp. Sta. Rec., 20 (1908-09): 1163; Chem. Abst., 3 (1909): 685.

$(12 \cdot 2)$

Vorkommen des Arsens in deutschen Weinen. Ber. Kgl. Lehranst. Wein-, Ohst- u. Gartenbau Geisenheim (1907), p. 180; Exp. Sta. Rec., 20 (190809): 1163; Chem. Abst., 3 (1909): 685.

(123) Teyxeira, G.

Ueber die Behandlung des Liebesapfels (der Tomate) mit Kupferverbindungen. Giorn. farm. Trieste, 2 (1897): 71; through Vierteljahr. Chem. Nahr. Genussmtl., 12 yr. (1897): 286, and Exp. Sta. Rec., 9 (1897-9S): 569.

(124) Trofinenko, M., and Obienoff, S.

Le vin des raisins traités aux arseniates. Prog. agr. vit., 65 (1916): 331; Bull. Agr. Intelligence, 7 yr. (1916): 1023; ('hem. Abst., 11 (1917): 2383. 
(12.5) Truelle, 1.

L'emploi des composé arsenimaux en arloriculure aux États-t’ni:. Bull. soc. nat. agr., 69 (1909): 99.

Lemploi des insectiriles arsenicaux en Angleterre. J. agr. pat., n. ser. 17 (1909): 298 .

(127) Tschirch, 1.

Jas Kupfer, 1) 13:3. Ferdinand Enke, stuttgart (1893).

(128) VAN SLYKE, 1. I.

Analyes of sprayed grapes. N. Y. Igr. Exp. Sta. Bull. 4 (1892): 56; Exp. Sta. Rer., 4(1892-93): 55.

(l:29) WEED, (. II.

The onmlination of incerticiles and fongirides. (thin Agr. Exp. Sta. Jull., Vol. 2. No. 7. 2 ser., No. 14, (1889): 186; Agr. Sicience, 3 (1889): 2633. (130) WELS, M.

Sur l'emplui des compusés arsenicaux en asrieulture, conviléré au point de vue le l'hygiène publique. Bull. atad. mexl., 3 ser., 61, (1909) 140 .

(131) Wheeler, 11. J.

(irapes sprayed with Bordeanx. R. 1. Agr. Exp. Sta. 4 Ann. Rpt. (1892): 84: Exp. Sta. Rixe, 4 (1842-43): 242.

(132) Wheeler, J. H.

Some pests and diseases of the vine, with remedies. Rutt. if Ann. Calit. state Vit. conven. (18s8): 63.

(133) Woovs, C. . .

Analyses for prion of apples sprayed with arenate of leal in mid-summer. Maine Agr. Exp. Sta. Bull. 224 (1914): 46; Exp. Sta. Rer., 31 (1)1f): 141; Chem. Alst.. 9 (1915): 503.

(134) Zecohini and Ravizza.

Copper in wine. Staz. sper. agrar. ital. 16 (1889): 73; through J. Sin. Chem. Incl., 8 (1889): 910.

\section{ADDITIONAL COPIES}

OF THIS PUBLICATION MAY BE PROCLRED FROM

THE SLPERINTENDENT OF DOCUMENTS

GOVERNMENT PRINTING OFFICE

WASHINGTON, D. C.

10 CENTS PER ('OPY 


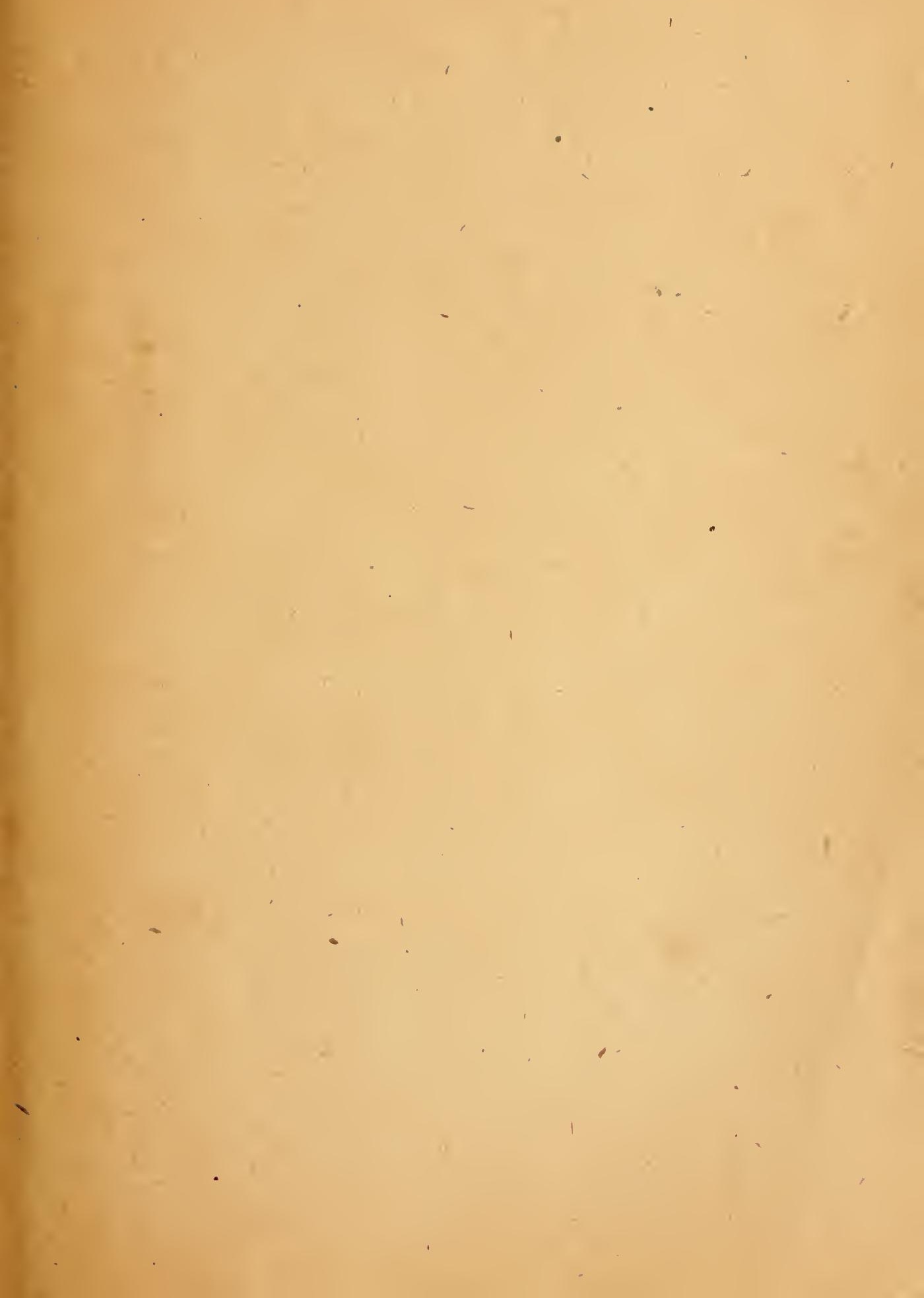


\section{LIBRARY OF CONGRESS}

